\author{
UNIVERSIDADE DE SÃO PAULO \\ ESCOLA DE COMUNICAÇÃO E ARTES
}

Hernani Dimantas

\title{
As Zonas de Colaboração METARECICLAGEM Pesquisa-Ação em Rede
}


Hernani Dimantas

\section{As Zonas de Colaboração METARECICLAGEM Pesquisa-Ação em Rede}

Tese apresentada ao Programa de PósGraduação em Ciências da Comunicação da Escola de Comunicação e Artes da Universidade de São Paulo para obtenção do título de Doutor em Ciências da Comunicação.

Área de Concentração: Teoria e Pesquisa em Comunicação.

Linha de Pesquisa: Comunicação e Ambiências em Redes Digitais.

Orientadora: Prof. Dra. Elizabeth Nicolau Saad Corrêa.

São Paulo

2010 


\section{@creative}

Atribuiçăo-Uso Não-Comercial-Compartilhamento pela mesma Licença 2.5 Brasil.

VOCÊ PODE:

copiar, distribuir, exibir e executar a obra

criar obras derivadas

SOB AS SEGUINTES CONDIÇŌES:

Atribuiçāo. Você deve dar crédito

ao autor original, da forma especi-

ficada pelo autor ou licenciante.

Compartilhamento pela

mesma Licença. Se voce

alterar, transformar, ou criar outra obra com base nesta,

voce somente poderá dis-

tribuir a obra resultante sob

Uso Nāo-Comercial. Voces

não pode utilizar esta obra

uma licença idèntica a esta.

Serviço de Biblioteca e Documentação da Escola de Comunicação e Artes da Universidade de São Paulo

Dimantas, Hernani.

As Zonas de Colaboração MetaReciclagem: pesquisa-ação em rede / Hernani Dimantas.

Orientadora: Prof. Dra. Elizabeth Nicolau Saad Corrêa. - São Paulo 2010.

154f. : il.

Tese (Doutorado) - Universidade de São Paulo, 2010.

1. Teoria e Pesquisa em Comunicação. 2. Comunicação e Ambiência em Redes Digitais. 3. MetaReciclagem. I. SAAD CORRÊA, E. II. Zonas de Colaboração.III. Redes Sociais.

CDD 21. ed. - 302 
DIMANTAS, Hernani. As zonas de colaboração MetaReciclagem: pesquisa-ação em rede. Tese apresentada à Escola de Comunicação e Artes da Universidade de São Paulo para obtenção do título de Doutor em Ciências da Comunicação.

Aprovado em:________

Banca Examinadora

Prof. Dr. Instituição:

Julgamento: Assinatura:

Prof. Dr. Instituição:

Julgamento: Assinatura:

Prof. Dr. Instituição:

Julgamento: Assinatura:

Prof. Dr. Instituição:

Julgamento: Assinatura:

Prof. Dr. Instituição:

Julgamento: Assinatura: 
A DANIEL PÁDUA 


\section{AGRADECIMENTOS}

A Felipe Fonseca, Dalton Martins e Glauco Paiva,

à Dani Matielo, Celso Goya, Angela Tijiwa e ao pessoal da Escola do Futuro, a todos os amigos MetaReciclagem.

Agradeço à orientação da Prof.Dra. Beth Saad.

Aos Professores Ricardo Teixeira e Mayra Rodrigues Gomes pelo momento da qualificação.

Agradeço à minha mãe Ada, à minha tia Berta e à Melanie.

À Laura e ao David

Agradeço, sobretudo, aos amigos: Cacau Freire, Drica Guzzi e Ricardo Kobashi. 
“...Aqui tem um bando de louco..." 


\section{Resumo}

As Zonas de Colaboração observadas a partir do movimento MetaReciclagem, uma rede que nasceu no campo da comunicação já no âmbito de uma cultura digital brasileira, em 2002, a partir da conversação na Internet de um grupo de pessoas sobre o desenvolvimento de blogs, reaproveitamento montagem/desmontagem de computadores, na interrelação entre essas ferramentas e a constituição de projetos colaborativos. O objeto de pesquisa é a relação comunicativa entre os membros do movimento que se contitui no ambiente virtual do MetaReciclagem. O método de pesquisa é a pesquisa-ação por meio de intervenção na lista de discussão do MetaReciclagem propondo uma metareflexão sobre as ações e resultantes do movimento ao longo dos anos. Abordagens quantitativa por meio de coleta de dados no ambiente virtual do MetaReciclagem (http://rede.metareciclagem.org) e qualitativa, coleta de depoimentos e conversações on-line dos membros que esboçaram suas opiniões e trocaram idéias a respeito do problema de pesquisa apresentado. Análise de dados por meio da técnica denominada análise de conteúdo e, dentro dessa, trabalhando com a técnica análise temática categorial. Os resultados demonstram que as Zonas de Colaboração são capazes de promover agenciamentos coletivos e intervenções sociais em políticas públicas de inclusão digital por meio das características da rede e do engajamento das pessoas. Tais transformações só acontecem pelo caráter não-hierárquico e não-institucionalizado do movimento do MetaReciclagem que promove a disseminação e replicação por meio de uma metodologia que privilegia a produção de subjetividade e a apropriação da tecnologia social em diferentes contextos culturais.

Palavras-chave: metareciclagem, redes sociais, epistemologia das redes, análise de conteúdo, análise temática categorial. 


\begin{abstract}
The Collaborative Zones observed in the MetaReciclagem (MetaRecycling Network) that arose out of the field of on-line communication, which was already enveloping Brazilian digital culture, in 2002, from a conversation on the internet among a group of people debating the development of blogs, reuse/recycling of computer parts, the interdependence of these tools and the constitution of collaborative projects. The purpose of this study is about the communication between the members of MetaRecycling Network (MetaReciclagem) and it's process as constituted in Collaborative Zones, result in actions of intervention in social situations in Brazil. This study proposes a research-action methodology, through intervention in the discussion lists of MetaRecycling, thus proposing a meta-reflection on the actions and results of the movement over the years. It involves quantitative (through the collection of data in the MetaRecycling virtual environment (http://rede.metareciclagem.org) and qualitative approaches, collecting on-line statements and conversations between members that sketch out their opinions and exchanging ideas regarding the issues of the presented research. It also involves data analysis by means of a technique entitled content analysis and, within this, working with categorical thematic technical analysis. The results have shown that Collaborative Zones are capable of leading to collective brokering and social interventions, as well as public policies involving digital inclusion through the characteristics of the network and consequent engagement with people. Such transformations can only happen because of the non-hierarchical and noninstitutionalized nature of the MetaRecycling movement, which promotes the dissemination and replication of methodology that privileges the production of subjectivity and the appropriation of social technology in different cultural contexts.
\end{abstract}

Keywords: metareciclagem, meta-recycling, social networks, epistemology of networks, content analysis, categorical thematic analysis. 


\section{Lista de Figuras e Tabelas}

Figura 1. Computadores Reciclados e Proposta Artística de Apropriação......... 73

Figura 2. Página Inicial da Lista de Discussão MetaReciclagem.

Figura 3. Proposta MetaReciclagem de Apropriação Tecnológica para a

Transformação social.

Figura 4. Imagem do Post de Intervençao na Lista de Discussão do MetaReciclagem.

Figura 5. Postagens no Twitter sobre a Intervenção na Lista do

MetaReciclagem.

Figura 6. Gráfico do Número de Postagens na Lista de Discussão do

MetaReciclagem por mês em 2005.

Figura 7. Gráfico do Movimento das Conversações na Lista do MetaReciclagem em 2005

Figura 8. Gráfico do Número de Postagens na Lista de Discussão do MetaReciclagem por mês em 2006

Figura 9. Gráfico do Movimento das Conversações na Lista do MetaReciclagem em 2006

Figura 10. Gráfico do Número de Postagens na Lista de Discussão do MetaReciclagem por mês em 2007

Figura 11. Gráfico do Movimento das Conversações na Lista do MetaReciclagem em 2007

Figura 12. Gráfico do Número de Postagens na Lista de Discussão do

MetaReciclagem por mês em 2008.

Figura 13. Gráfico do Movimento das Conversações na Lista do MetaReciclagem em 2008

Figura 14. Gráfico do Número de Postagens na Lista de Discussão do MetaReciclagem por mês em 2009

Figura 15. Gráfico do Movimento das Conversações na Lista do

MetaReciclagem em 2009

Figura 16. Gráfico do Número de Postagens na Lista de Discussão do MetaReciclagem por mês em 2010

Figura 17. Gráfico do Movimento das Conversações na Lista do 
MetaReciclagem em 2010 ........................................................... 98

Figura 18. Postagens MetaReciclagem de 2005 a 2010.............................. 98

Figura 19. Gráfico do Movimento das Conversações de 206 a 2009................ 99

Figura 20. Mapa Esporos do MetaReciclagem no Brasil em 2010.................. 101

Figura 21. Gráfico das Categorias Principais de Análise de Conteúdo.............. 107

Figura 22. Nuvem de Tags a Partir de Frases ou Expressões Classificadas na Categoria Agenciamentos Coletivos/Transformações..................................... 110

Figura 23. Nuvem de Tags a Partir de Frases ou Expressões Classificadas na Categoria Zonas de Colaboração.

Figura 24. Nuvem de Tags a Partir de Frases ou Expressões Classificadas na Categoria Apropriação da Tecnologia Social.

Figura 25. Nuvem de Tags a Partir de Frases ou Expressões Classificadas na Categoria Características da Rede.

Figura 26. Nuvem de Tags a Partir de Frases ou Expressões Classificadas na Categoria Metodologia

Figura 27. Gráfico Temáticas de Zonas de Colaboração................................. 116

Figura 28. Agenciamentos Coletivos e suas Categorias Temáticas................. 122

Figura 29. Apropriação da Tecnologia Social e suas Categorias Temáticas...... 134

Tabela 1. Esquema de Coleta de Dados..................................................... 81

Tabela 2. Participantes da Lista de Discussão do MetaReciclagem x Ano........ 86

Tabela 3. Número de Postagens na Lista do MetaReciclagem x Ano................ 87

Tabela 4. Lista de Esporos no Brasil Cadastrados no Site da Rede

MetaReciclagem até o 1ํ Semestre de 2010............................................... 102

Tabela 5. ConecTAZes Registrados no Site do MetaReciclagem até o $1^{\circ}$

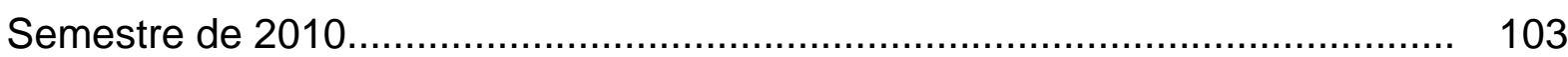




\section{Sumário}

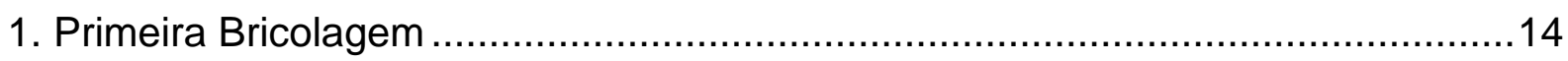

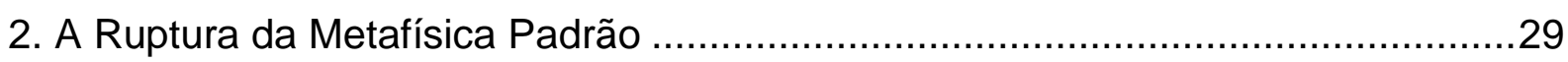

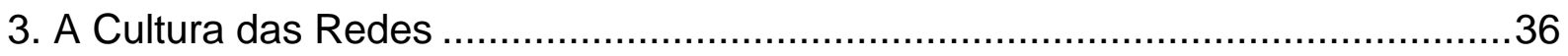

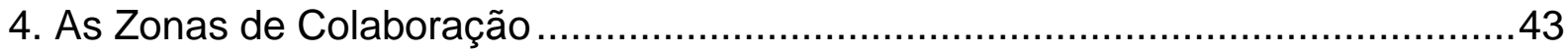

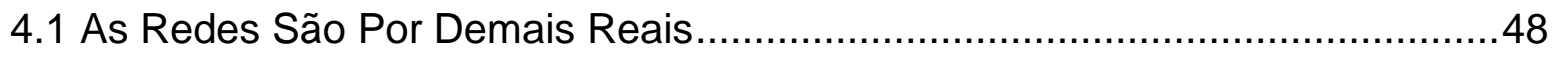

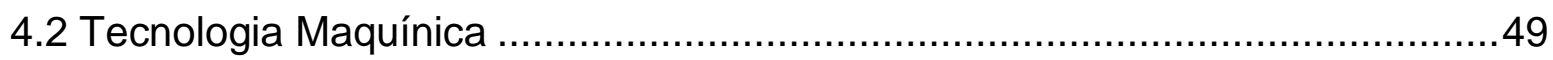

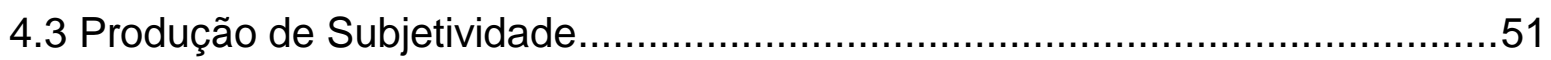

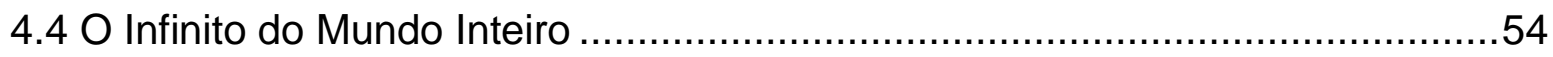

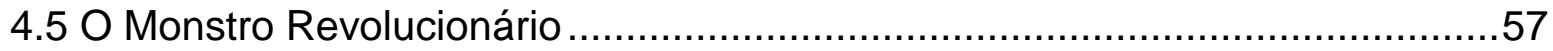

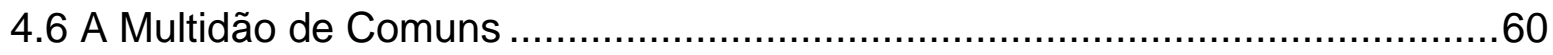

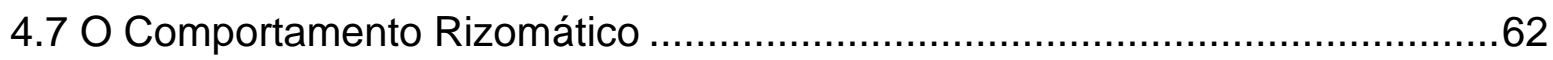

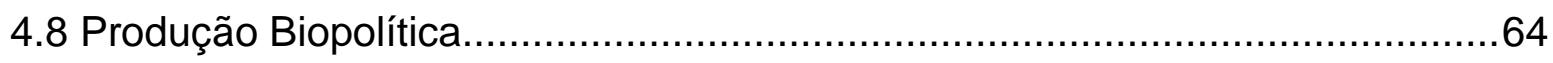

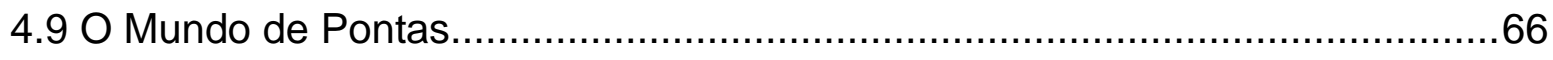

5. Objeto, Hipóteses e Método de Pesquisa ………….......................................

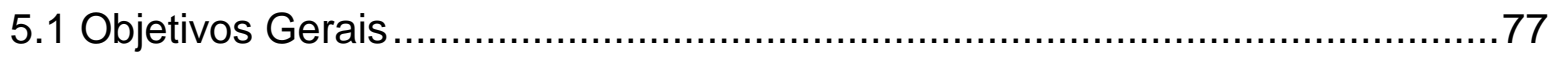

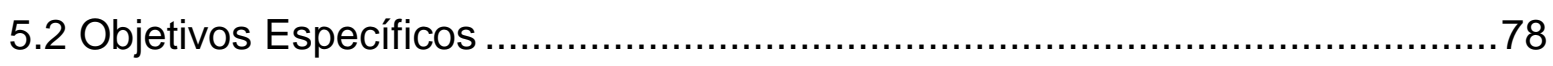

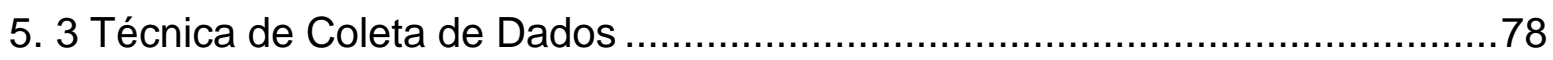

5.3.1 Técnica de Coleta de Dados Quantitativos ……….................................78

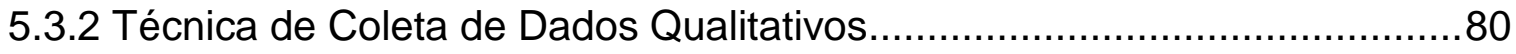

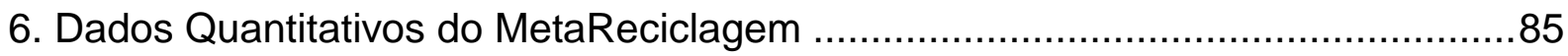

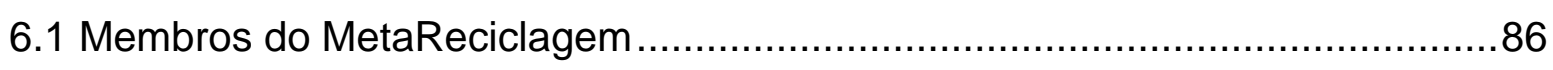

6.2 Postagens e Discussões na Lista do MetaReciclagem ...................................87

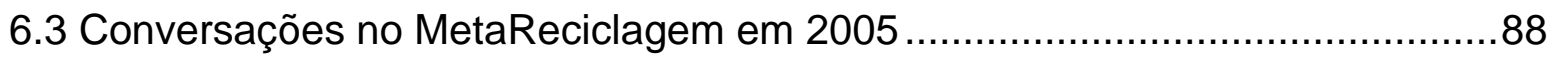

6.4 Conversações no MetaReciclagem em 2006 ……....................................90

6.5 Conversações no MetaReciclagem em 2007 ...............................................92

6.6 Conversações no MetaReciclagem em 2008 ...............................................94 


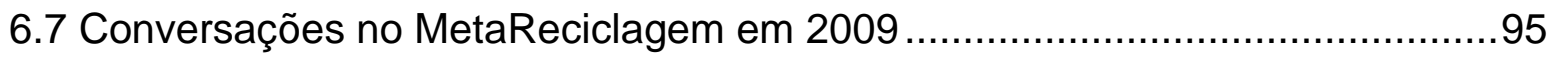

6.8 Conversações no MetaReciclagem em 2010 .............................................97

6.9 Total de Postagens MetaReciclagem 2005 a 2010 .....................................98

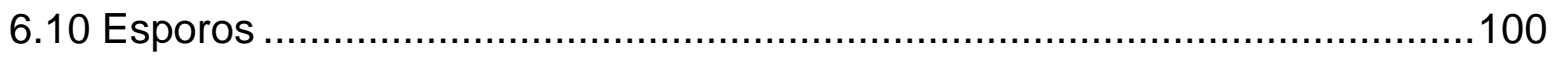

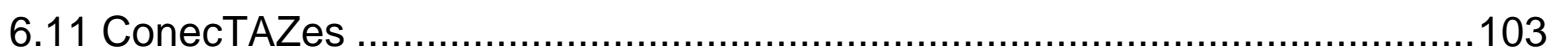

7. Resultados da Análise Temática do Conteúdo..............................................107

7.1 O que se diz sobre As Zonas de Colaboração …….....................................115

$7.2 \mathrm{O}$ que se diz sobre os Agenciamentos Coletivos e Transformações .............122

$7.3 \mathrm{O}$ que se diz sobre as Características da Rede ..........................................127

$7.4 \mathrm{O}$ se diz sobre Apropriação da Tecnologia Social........................................133

7.3.5 O que se diz sobre Metodologia .......................................................139

8. Implicações da Pesquisa: “...Aqui tem um Bando de Louco...” ..........................142

9. Referências Bibliográficas ........................................................................148 


\section{Primeira Bricolagem}

Em 1999, foi lançado o Manifesto Cluetrain, apresentando uma série com noventa e cinco teses que prenunciavam o fim dos negócios como até então conhecíamos. De acordo com os autores - Chris Locke, Rick Levine, Doc Searls e David Weinberger - as empresas deveriam ouvir o que os mercados estavam 'dizendo', não só na mídia em geral, mas principalmente na Internet, onde essa conversa se manifestava de modo aberto, honesto, direto, engraçado e até, chocante.

Muitas vezes explicando, reclamando, brincando ou falando sério, a voz humana em uma conversação genuína não poderia ser falsificada. Dessa forma, o Cluetrain marcou o início de uma poderosa conversação global que embalou os desejos de várias pessoas que estiveram conectadas na época:

Através da Internet, as pessoas estão descobrindo e inventando novas maneiras de compartilhar rapidamente o conhecimento relevante. [...] mercados estão ficando mais espertos - e mais espertos que a maioria das empresas. (LEVINE et. al., 2001, p. xxii-xxiii).

De fato, naquela época, a Internet estava sendo povoada. As redes podem ser muito simples quando observadas do ponto de vista das conversações. A apropriação ${ }^{1}$ dessa rede não aconteceu como as empresas imaginavam ou estavam, a princípio, interessadas. Ao contrário, um movimento emergente de pessoas conversando com pessoas começou a trazer mudanças para o mercado. Ao invés das inovações partirem das grandes organizações e empresas, os usuários se apropriaram das tecnologias de informação e comunicação para formar vários pontos comunicativos onde se trocavam idéias, opiniões e sobretudo, conhecimento. As mudanças trazidas pelo Manifesto Cluetrain constituem-se referências primordiais para estudar as Zonas de Colaboração em uma rede como a Internet, a

1. Apropriação: o termo neste trabalho será empregado com o sentido de apoderar-se ou tomar como propriedade, como seu; arrogar-se a posse de, referindo-se às ferramentas de informação e comunicação. 
partir deste trabalho de pesquisa.

Eric Raymond (1999), um dos líderes do movimento do software livre, presidente da Open Source Initiative (OSI) e autor de diversos artigos incluindo $A$ catedral e o bazar ${ }^{2}$ influenciou o mundo do software de código aberto ao mencionar que: "O Cluetrain está para o Marketing e para as Comunicações assim como o movimento dos Códigos Abertos está para o desenvolvimento de Software" (RAYMOND, 1999). Com esta comparação o autor ressaltou o caráter "anárquico, bagunçado, rude e infinitamente mais poderoso" da Internet capaz de tornar o conhecimento relevante acessível para a diversidade de interesses humanos empenhados em encontrá-lo.

"Os mercados são conversações; falar é fácil e o silêncio é fatal". Esse era o meu mantra na virada do milênio. Foi nesse momento, início dos anos 2000, que a Internet no Brasil deu uma guinada em consequência do estouro da bolha ${ }^{3}$ na $\mathrm{NASDAQ}^{4}$, momento em que a maioria dos grandes projetos de sites e portais não sustentou mais o fôlego financeiro para continuar no mercado. Nesse período passei a desenvolver o projeto Marketing $\mathrm{Hacker}^{5}$ a partir de um contexto da formação de uma nova geração de comunicadores que, ao contrário das gerações anteriores, se constituía de forma independente dos grandes meios de comunicação e possuía, nas ferramentas de edição na Internet - os blogs - o meio de criação, difusão e troca.

\footnotetext{
2 A catedral e o bazar é citado neste trabalho de pesquisa por abordar o movimento informal de compartilhar o conhecimento na Internet e suas implicações nas relações de poder.
}

3. Em 2001, empresas, serviços, políticos, ONGs inseriram-se na Internet para disponibilizar serviços e produtos. O e-commerce surgia como um novo canal de vendas. O dinheiro de outros setores começava a ser canalizado para sites, produtos e serviços da rede. A Internet prometia um futuro rico, infinito e cheio de possibilidades. Em maio de 2001, a "Bolha da Internet", ou seja, o fenômeno de supervalorização das empresas pontocom e de suas ações "estourou". Foi o fim de centenas de pequenas empresas virtuais que davam seus primeiros passos. Fontes: Anos 00: empresas virtuais, Nasdaq e a Bolha. Portal Terra Tecnologia. São Paulo, 2001. Disponível em: http://tecnologia.terra.com.br/internet10anos/interna/0,,Ol542324El5026,00.html Acesso em 31 maio 2009. NORRIS, Floyd. (2001). The New York Times. Disponível em: http://www1.folha.uol.com.br/folha/dinheiro/ult91u16499.shtml Acesso em 31 maio 2009.

4. NASDAQ (National Association of Securities Dealers Automated Quotations - Pregão Automático da Associação Nacional dos Corretores), primeira bolsa de valores eletrônica do mundo e o maior mercado eletrônico dos Estados Unidos. Fundada em 08 de fevereiro de 1971 pela SEC - National Association of Securities Dealers. Em 2007 a Nasdaq adquiriu o operador sueco de bolsas OMX e passou a se chamar Grupo NASDAQ OMX. Atualmente, empresa lista mais de 3.900 empresas com ramos variados na indústria, como tecnologia, varejo, comunicações, serviços financeiros, transporte, meios de comunicação e tecnologia. Disponível em: www.nasdaq.com. Acesso em: 31 maio 2009.

5. Marketing Hacker: foi o meu primeiro blog. Participei ativamente da construção daquilo que veio a ser a blogosfera tupiniquim. Em 2003 as idéias disponibilizadas no blog deram origem ao livro Marketing Hacker. Disponível em: http://comunix.org/content/marketing-\%C3\%A9-hacker Acesso em 31 maio 2009. 
Estamos na era do conhecimento. Uma sociedade baseada no fluxo das informações, não mais na quantidade de bens produzidos. Nesse cenário um novo sistema começou a florescer. Fundamentado na utilização da tecnologia. Os hackers estão moldando um novo contrato com a sociedade. Hackers crêem que a revolução digital deve ser traduzida em um tempo lúdico para a humanidade. (...) Acreditam no conhecimento livre. A ética hacker expressa a crença em que o compartilhamento da informação é um poderoso e positivo bem. (DIMANTAS, 2003, p. 35-36).

O meu objetivo foi entender e discutir as mudanças que a Internet estava introduzindo no mundo dos negócios e na área de marketing. Havia um descompasso entre as práticas apoiadas em conceitos da comunicação de massa e as propostas comunicativas com as novas linguagens, práticas e possibilidades advindas do uso dos novos meios digitais.

O Marketing Hacker tratou da influência da ética hacker ${ }^{6}$ e da cultura de escovar bits ${ }^{7}$ para a área do conhecimento. No jargão hacker, a ética traduz a crença em que o compartilhamento da informação é um poderoso e positivo bem. $\mathrm{Na}$ prática, isto significa um dever ético de trabalhar sob um sistema aberto de desenvolvimento, no qual cada um disponibiliza a sua criação para outros usarem, testarem e continuarem o desenvolvimento. Para Himanen (2001, p. 72), os argumentos éticos do modelo hacker são os mais importantes. O aspecto mais interessante da ética dos hackers é sua oposição à velha ética protestante. Uma relação mais livre é também necessária na economia informal cuja base principal é a criatividade.

A ética protestante incluiu a idéia do "time is money". Governada por essa ética, muito de nossa economia se tornou mais e mais veloz. Nosso tempo de lazer está diminuindo e se tornando apenas obrigação, um processo que poderia ser chamado de "Fridayzation of Sunday". Pessoas estão constantemente correndo de um compromisso a outro, tentando sobreviver dentro dos prazos, do "deadline", expressão que é significativa do nível de emergência e exaustão a que se chegou. Da perspectiva de um hacker, esse é um resultado estranho do progresso tecnológico. $O$ aspecto mais interessante da ética dos hackers é opor-se frontalmente à velha ética protestante. Os hackers crêem que a revolução digital deve ser traduzida também em um tempo

6. Hacker: nesse trabalho entendemos hacker como artesão da tecnologia, conforme Himanen (2001, p.7).

7. Escovar os bits: expressão que significa esmiuçar, verificar cuidadosamente, conferir as rotinas de programação de um programa de computador com a função de otimizá-las ao máximo. 
lúdico para a humanidade. Trata-se de reverter o processo, transformar a sexta-feira no domingo ("The Sundayization of Friday"). Uma relação mais livre é também necessária na economia informal cuja base principal é a criatividade: você precisa permitir a formação de estilos individuais se desejar que coisas interessantes sejam criadas. $\mathrm{Na}$ ética protestante, a idéia do dinheiro era um valor em si mesmo. Isso não significa que os hackers sejam ingênuos ou anticapitalistas. Na nova economia, a idéia de propriedade se estendeu para a noção de informação em uma escala jamais vista anteriormente. (HIMANEN, 2003 ${ }^{8}$ ).

A cultura hacker tem origens no Massachusetts Institute of Technology (MIT) em meados da década de 60 e em outros laboratórios americanos, como o o Xerox Palo Alto Research Center (PARC).. Essa cultura coloca o ser humano no centro do universo e passa a desenvolver uma nova relação para satisfazer essa variável. As Zonas de Colaboração surgem a partir dessa visão. Inseridos na ética hacker estão "os caras" do software de código livre, do GNU-Linux, Bell Labs, o MIT AI Lab, UC Berkeley, que se tornaram a origem de inovações lendárias e ainda fortes. Linux foi o primeiro projeto a fazer um esforço consciente e bem-sucedido ao utilizar o mundo inteiro como sua reserva de talentos. Eric Raymond (1999) relata:

\begin{abstract}
Eu não acho que seja uma coincidência que o período de gestação do Linux tenha coincidido com o nascimento da World Wide Web, e que o Linux tenha deixado a sua infância durante o mesmo período em que viu a expansão da indústria de ISP ${ }^{9}$ e a explosão do principal interesse da Internet. (19931994). Linus foi a primeira pessoa que aprendeu como jogar com as novas regras que a onipresente Internet tornou possível. Embora uma Internet barata fosse uma condição necessária para que o modelo do Linux evoluísse, eu penso que não foi uma condição por si só suficiente. Outro fator vital foi o desenvolvimento de um estilo de liderança e conjunto de formalidades cooperativas que permitiria aos desenvolvedores atrair co-desenvolvedores e obter o máximo suporte do ambiente. (RAYMOND, $\left.1999^{10}\right)$.
\end{abstract}

\footnotetext{
${ }^{8}$ Citação retirada de texto da Internet: http://www.softwarelivre.org/news/904 Acesso em 25 jan. 2009.

${ }^{9}$ ISP: Internet Service Provider Industry.

${ }^{10}$ Citação retirada de livro disponível na Internet http://www.geocities.com/CollegePark/Union/3590/pt-cathedralbazaar.html> Acesso em 08 jan. 2008.
} 
O mundo à nossa volta progride. "Linkados"11 à rede podemos participar e observar as pessoas desenvolvendo projetos próprios. Comunidades conversando e criando fórmulas alternativas. Empresas desenvolvendo negócios baseados na criatividade dos seus clientes. Não é para menos. A informação anda na frente, um passo adiante dos setores relacionados. Não é por acaso que o movimento hacker está atrelado desde os seus primórdios à programação de software e se estendeu através da indústria da informação.

Em The hacker Ethic and the spirit of the information age, Pekka Himanen (2001) identifica a questão hacker:

A questão principal, então, passou a ser como seria se os hackers começassem a ser analisados sob uma perspectiva mais abrangente. O que significa o desafio lançado por eles? Sob essa ótica, a palavra hacker é utilizada para descrever uma pessoa com uma determinada obsessão pelo trabalho, relação essa que está ficando cada vez mais aparente na Era da Informação. Desse ponto de vista, a ética dos hackers é uma nova ética de trabalho que desafia o comportamento conforme explicou Max Weber em seu clássico A Ética Protestante e o Espírito do Capitalismo. (...) Contudo, a ética dos hackers é, acima de tudo, um desafio para nossa sociedade e para nossa existência. Além da ética do trabalho, o segundo aspecto é a ética do dinheiro - um aspecto definido por Weber como outro componente da ética protestante. É certo que o compartilhamento das informações mencionado na definição da ética dos hackers não é a forma predominante pela qual se faz dinheiro. Ao contrário, as pessoas ganham dinheiro, na maior parte dos casos, quando detém a informação. (HIMANEN, 2001, p. 23)

As contradições apontadas na análise de Himanen (2001, p. 23) sugerem a nova forma de negócios e trabalho orientada pela criação de Zonas de Colaboração. Os hackers surgiram no ambiente universitário. Com as contas balanceadas é fácil, muito fácil, romper com as estruturas impostas pelo capitalismo. Richard Stallman ${ }^{12}$, tornou possível, por exemplo, priorizar o desenvolvimento de um driver para impressora e quebrar com os modelos da indústria de software. No Brasil,

\footnotetext{
${ }^{11}$ Nesse trabalho de pesquisa o autor utilizou anglicismos e verbos conforme o uso comum na Internet: Entre eles: linkar, deletar, hackear, scraps, nicknames, blogs, bloggar e outros termos.

12. Fundador do movimento Free Software, do Projeto GNU, e da Free Software Foundation(FSF) ("Fundação para o Software Livre"). Disponível em:< http://pt.wikipedia.org/wiki/Richard Matthew Stallman $>$ Acesso em: 26 jul. 2007.
} 
entretanto, ele morreria de fome. Continuando nessa linha de raciocínio, Himanen (2001) define o mundo hacker e suas motivações pelo desejo de construir algo para a comunidade. Algo que seja valoroso. A reputação aparece aqui como uma forma de 'remuneração'. Mas ninguém vive de reputação. A originalidade das conversações que acontecem no Hemisfério Sul devem ser analisadas por outro viés.

Ser hacker é uma forma de sobrevivência. Esse ponto de vista desloca o olhar da cibercultura para o âmbito cultural local, entrando nas relações que acontecem na sociedade brasileira. A colaboração é uma estratégia de sobrevivência nas periferias do Brasil. Não é preciso aprofundar na questão das perversidades das classes dominantes já que é possível focar na forma como os brasileiros descobrem o atalho para o futuro.

É lógico que o debate na sociedade virtual está osmoticamente invadindo outros espaços sociais. Alguns princípios do ser humano estão sendo transformados. O novo bom senso aceita a revolução digital como propulsora de uma nova ordem. Aceita a anarquia como uma forma viável de contrabalançar os poderes: aceita que o conhecimento deva ser livre e, portanto, aceita o direito que as pessoas comuns têm de compartilhar esse conhecimento. Diante dessa realidade, as empresas e o governo tornam-se muito mais frágeis. Não se trata de acreditar que haveria um "muro de Berlin" que dividisse a sociedade em castas de opressores e oprimidos, de poderosos e fracos, de produtores e consumidores. Nesse caso teríamos de acreditar numa sociedade maniqueísta, que julgasse sempre o bem e o mal. É nesse contexto que a multidão hiperconectada vem promover a ruptura da ética protestante, que ajudou a evolução da sociedade industrial. Pois, na era do conhecimento, valores são sobrepujados por uma outra ética: a Ética Hacker proposta na sociedade da informação, adotada desde o início pelo movimento do software livre, a ética capaz de romper com os paradigmas estabelecidos e criar Zonas de Colaboração.

Para entender esta ruptura dos paradigmas, temos que pensar e participar. Um novo sistema está nascendo. Acredito que esteja surgindo uma consciência 
inequívoca de que a construção de baixo para cima tem muito a oferecer em prol do desenvolvimento do processo coletivo. Uma sociedade que sobrevive e se recria em sua própria diversidade. E, assim, tudo muda. Crianças aprendem a colaborar, a desenvolver projetos on-line e a espelhar os sonhos no ambiente Web. O mundo virtual não é diferente do nosso bom e querido mundo presencial. A Internet está ensinando os usuários a se interrelacionar nesse espaço virtual onde não existe segredo, mas apenas boa vontade e obstinação.

Criar para a sociedade. Fazer acontecer independentemente do retorno financeiro a curto prazo. É esta a grande novidade. O percurso é simples e virtual. Qualquer pessoa com um computador conectado à rede e com um pouco de conhecimento tem a possibilidade de participar voluntariamente de alguns projetos importantes. E sem dúvida essa é a melhor opção.

Richard Barbrook (2000, p. 8) diz que no fim do século 20, o anarcocomunismo não estava mais confinado entre os intelectuais de vanguarda. $O$ que antes fora revolucionário agora se tornou banal. Ele diz que as pessoas participam dessa hi-tech gift economy (economia das trocas), ou seja, uma economia onde os bens informacionais estão disponíveis abundantemente e fluem livremente. Uma economia que, de certa forma, rege a prática do conhecimento livre. Para muitas pessoas a gift economy é simplesmente o melhor método de colaboração no espaço cibernético. Nessa economia mista da Rede, o anarco-comunismo é uma das realidades do cotidiano.

Colaboração é a palavra do século XXI. Linus Torvalds causou um alvoroço enorme ao liberar o código numa lista de debates. Colaboração como fonte de riqueza. Colaboração para fazer qualquer coisa que o desejo provoque. Colaboração como condição de sobrevivência. Podemos perceber que alguma coisa está modificando os rumos da economia por meio do trabalho imaterial. Essa forma de trabalho foi caracterizada por Hardt e Negri (2005) como produtora de informação, conhecimento, idéias, imagens, relacionamentos e afetos. Apresentando a tendência de não limitar-se ao domínio estritamente econômico, mas desenvolvendo a esfera social. Para os autores, o trabalho imaterial "não cria apenas meios através dos 
quais a sociedade é formada e sustentada; (...) [mas] produz diretamente relações sociais tornando-se uma força social, cultural e política" (HARDT; NEGRI, 2005, p. 100-101). Tal relação, em termos filosóficos, também envolve a criação e a reprodução de novas subjetividades na sociedade.

Yochai Benkler (2006, p. 60) em The Wealth of the Networks mencionou a coexistência de duas formas de economia: uma advinda das negociações no mercado tradicional onde as trocas se realizavam por meio da moeda financeira e outra denominada pelo autor por economia do compartilhamento ou peer-production economy, advinda da transferência mútua e simultânea de informações, principalmente na Web.

\begin{abstract}
“(...) mais radical, novo e difícil de acreditar por aqueles que têm observado é o crescimento efetivo, em larga escala, dos esforços cooperativos - a produção por pares da informação, do conhecimento e da cultura. (...) em todo o domínio da informação e da produção cultural. (BENKLER, 2006, p. 5)
\end{abstract}

Nessa segunda forma o agir econômica encontra-se vinculado a um valor e a um tipo de moeda de troca que nem sempre é da ordem financeira. Norteamentos tais como critérios de reputação, reconhecimento, visibilidade, vontade de participação ou cooperação são alguns valores que podemos pensar como pertinentes.

A conversação on-line está gerando novas formas de encarar os problemas. Criando novas perspectivas, novas ferramentas, e um novo tipo de incentivo intelectual. O resultado é um ganho incomensurável na habilidade de aprender e ensinar, refletida na capacidade de brincar com seriedade. A Internet abriu as portas para o inter-relacionamento entre pessoas e empresas modificando as estruturas de poder, antes nas mãos das corporações, e agora, resgatadas pelos consumidores.

Existem muitas Internets. Na sua natureza, a Internet se descola da lógica do mass media decompondo-se em numerosas intervenções, conversas de pequenos grupos, numa infinidade de espaços comunicacionais, constituindo diversos ambientes de compartilhamento e catalisação do conhecimento. Quando falamos de 
Internet estamos nos referimo às pessoas que nela habitam, que usam Google, email, Orkut, MSN, Twitter, blogs, Del.icio.us, YouTube, Flickr, Torrents, Facebook e inúmeras outras redes que estão sendo construídas a todo momento. Pessoas que trocam e-mails com amigos, que usam o Skype para conversar. Enfim, são pessoas comuns, freqüentadoras de um mundo invisível e formado por redes que se autoalimentam, se cruzam, se miscigenam. A rede mistura espaços. E assim todos são bem-vindos à cultura da recombinação (remix). Nesse sentido, podemos perceber hoje as transformações que essa poderosa conversação global começou.

Como resultado direto, mercados ficaram mais espertos. Conforme Weinberger $\left(2004^{13}\right)$ "os blogs são uma prova inesperada da idéia central do Cluetrain, isto é, que pessoas estão na Internet porque ela permite que cada um expresse sua voz". Rheingold (2003, p. 120) diz: "os blogs são os novos pilares da democracia, locais para discussão e debate essenciais para que a democracia participante funcione".

Pode-se dizer que a Internet é a obra-prima hacker, uma vez que o compartilhamento tornou-se fonte de riqueza. Entretanto, esse movimento não ficou restrito à arena tecnológica. Atualmente, ser um hacker independe do conhecimento inerente à área da computação. Faz mais sentido pensar no artífice, devido à criatividade do ser humano em rede. O Marketing Hacker, em 2003, colocou no campo de forças as possibilidades de difusão do conhecimento livre e a crença de que as tecnologias da informação e comunicação atuavam num processo silencioso, uma revolução que não seria televisionada, mas capaz de provocar mudanças profundas na sociedade.

Hoje, um sinal verde do gtalk indica quem da minha rede está on-line. Falo com um monte de gente ao mesmo tempo. Fecho assuntos importantes, agendo um almoço, um jantar e converso com toda a equipe de trabalho. Estão todos conectados. A vida é diferente daquela que aprendemos a viver e as pessoas estão conversando também de diferentes modos. Os espaços informacionais são tratados aqui como espaços que contemplam comunidades, softwares sociais, ferramentas

\footnotetext{
${ }^{13}$ Referência extraída de texto na Internet: http://www.guardian.co.uk/technology/2004/may/27/media.newmedia> Acesso em: 20 jul. 2008.
} 
de conversação e comunicação. Henri Jenkins (2008, p. 58) menciona apropriações e empodoremento de consumidores por meio de trocas e utilizando as tecnologias de informação e comunicação. Denominando de "cultura do conhecimento" o que, neste trabalho de pesquisa, trato por um movimento disforme de Zonas de Colaboração que emerge a partir das conversações em comunidade na rede. $O$ autor fala da disputa entre amadores e produtores: enquanto um grupo tenta se apropriar do conhecimento o outro tenta protegê-lo de tal apropriação, representado o movimento da cultura do expert versus a cultura da inteligência coletiva.

A Internet trouxe mudanças na forma de organização social na qual observamos a migração de uma cultura de massa para uma cultura descentralizada com vários focos de produção. As tecnologias de informação e comunicação formaram o cenário lógico para a expansão das comunidades, redes sociais, ou daquilo que mais especificamente denominamos, neste trabalho, por Zonas de Colaboração. Há de se considerar a multiplicidade dessas relações que visam à difusão de novos agenciamentos, seja sob a forma de comunidades de esforços colaborativos de inúmeros desenvolvedores de software livre, dos contribuintes do Slashdot ${ }^{14}$, do Overmundo ${ }^{15}$, e, principalmente, do movimento do MetaReciclagem nosso objeto de pesquisa: uma rede distribuída que atua desde 2002 no desenvolvimento de ações de apropriação da tecnologia, de maneira descentralizada e aberta ${ }^{16}$.

De fato, percebe-se que esses espaços informacionais são impulsionados por uma conversação assíncrona que, ao emergir, traz a reboque uma nova forma de organização descentralizada, tanto do ponto de vista da organização per si como da

14. Slashdot é um dos maiores sites de notícias em Tecnologia da Informação na Internet, com 50 milhões de page views por mês. As notícias recebem um hanking por número de comentários inseridos pelos leitores. $\mathrm{E}$ os comentaristas são reputados pelo compartilhamento de conhecimento sobre o assunto. Disponível em: http://slashdot.org/ Acesso em 31 maio 2009.

15. Overmundo: website colaborativo sobre a cultura brasileira lançado em março de 2006 com o objetivo de dar visibilidade na Internet à produção cultural brasileira que não era vista na grande mídia. Qualquer visitante pode criar uma conta e publicar, votar ou sugerir edições ao conteúdo do site. Disponível em: http://www.overmundo.com.br/ Acesso em 31 maio 2009.

16. MetaReciclagem: a rede começou em São Paulo, no ano de 2002, em parceria com a ONG Agente Cidadão, como um projeto inicial de captação e remanufatura de computadores usados que posteriormente eram distribuídos para outros projetos sociais. O MetaReciclagem sempre teve por base a desconstrução do hardware, o uso de software livre e de licenças abertas, a ação em rede e a busca por transformação social. Disponível em: http://rede.metareciclagem.org/wiki/MetaReciclagem Acesso em 31 maio 2009. 
comunicação mediada pela tecnologia hiperconectada. A habilidade de agir em Zonas de Colaboração é mencionada por Clay Shirky (2008, p. 20-21) em Here Comes Everybody:

(...) 'software social', 'mídias sociais', e assim vai. Apesar de haver algumas distinções entre esses termos, a idéia principal é a mesma: estamos vivendo em meio a um surpreendente crescimento em nossa habilidade de cooperar uns com os outros, de tomar decisões coletivas, tudo fora da camada tradicional das instituições e das organizações. (SHIRKY, 2008, p. 20-21).

Essa cultura de rede se expandiu rapidamente. Pessoas comuns se apropriam das tecnologias e reverberam em suas comunidades aquilo que aprenderam. A replicação tornou-se a forma pela qual nos valemos para disseminar o conhecimento e ensinar nesse novo paradigma informacional. Pessoas que estão se conectando com outras pessoas. Aprendendo e ensinando na busca de um mundo melhor. Essa é a promessa da Web.

No novo contexto da formação (informal) de uma recente geração de comunicadores constituída por "amadores" que organizam a informação para públicos específicos em múltiplas interfaces, é que foi possível em minha dissertação de mestrado publicada como livro intitulado Linkania: a sociedade da colaboração iniciar um caminho para pensar essa rede e suas prováveis intervenções comunicacionais.

Para compreender a ruptura de paradigmas em que a linkania implica, temos que pensar e participar (...) é preciso esquecer o comando e o controle. Assim, surge uma consciência inequívoca de que a construção de baixo para cima tem muito a oferecer para o desenvolvimento do processo coletivo, revelando uma sociedade que sobrevive e se recria na própria diversidade. Esse processo envolve a participação de muitos atores. Há uma rede em que a natureza adquire instâncias "maquínicas" e esdrúxulas, às vezes desconcertantes. (...) $\bigcirc$ que importa é $O$ ato de linkar. (DIMANTAS, 2010, p. 21).

Trata-se de um caminho que parte da desconstrução da metafísica padrão, apoiado no trabalho de David Weinberger (2006) em The hyperlinked metaphysics 
no qual o autor contrapõem à visão filosófica "conteinerizada" do mundo à ação online: "O hyperlink rompe a barreira do tempo, do espaço, do idioma e do bom senso. Uma transformação mais filosófica do que tecnológica." (WEINBERGER, $2006{ }^{17}$ ).

Esta transformação filosófica faz sentido quando entendemos a ruptura como uma possibilidade de se pensar a tradição filosófica baseada nas relações de afeto conforme Espinosa define em Ética (Spinoza, 1677/2008, p.185). Faz-se pertinente retomar alguns conceitos desse autor ao considerarmos a conversação em rede uma vez que, por meio de método dedutivo, ocupou-se da causa e dos efeitos dos afetos entre objetos e pessoas, reciprocamente, traduzindo ética como uma construção ontológica apoiada no movimento das diferentes relações. Deste modo, o conceito inicial de afeto "uma idéia pela qual a mente afirma a força de existir" (SPINOZA, 1677/2008, p. 283) vinculado à sua potência, como "as afeições do corpo, pelas quais sua potência de agir é aumentada ou diminuída, estimulada, refreada(...)" (SPINOZA, 1677/2008, p. 163) é importante nesse trabalho, bem como o conceito da potência, a utilidade dos afetos:

É útil ao homem aquilo que dispõe o seu corpo a poder ser afetado de muitas maneiras, ou que o torna capaz de afetar de muitas maneiras os corpos exteriores; e é tanto mais útil quanto mais torna o corpo humano capaz de ser afetado e de afetar os outros corpos de muitas maneiras. E, inversamente, é nocivo aquilo que torna o corpo menos capaz disso. (SPINOZA, 1677/2008, p. 311).

O estudo dos afetos proporciona perceber o encontro dos comuns na rede, no que poderia ser visto, inicialmente, como um amontoado de coisas, pessoas e projetos que, aparentemente, não possuem nada em comum: uma miscelânea. (WEINBERGER, 2007, p. 86). Tais relações de afeto também são propostas como links neste trabalho de pesquisa. A desorganização da rede dá poder aos pequenos, permitindo sua organização em links a partir dos interesses dos usuários, esse é o poder dos pequenos grupos. O movimento dos afetos que aumenta ou diminui a potência das pessoas na rede acontece em uma sociedade que se configura rizomática (DELEUZE; GUATTARI, 1995, p. 15) e abarca multiplicidades que

\footnotetext{
${ }^{17}$ Referência extraída de texto da Internet: http://www.hyperorg.com/misc/metaphysics/ Acesso em: 31 março de 2009.
} 
produzem subjetividades em instâncias informacionais diferenciadas.

Pensamos aqui em hipóteses para observação dessa ação em rede, e nas possibilidades de mensurar essa ação coletiva em torno de um comum. Para isso, retomamos o exemplo da Catedral e o Bazar que partiu de uma experiência de colaboração em rede no desenvolvimento de software por Raymond, no final dos anos 90 .

A grande dúvida do autor de Catedral e o Bazar surgiu com uma postura bastante cética sobre o estilo Linux de desenvolvimento. Raymond que já havia participado do desenvolvimento de Unix e de outros códigos abertos por dez anos, sendo um dos primeiros a contribuir para o projeto GNU em meados dos anos 80, acreditava que softwares mais importantes, como sistemas operacionais e ferramentas grandes precisavam ser construídos no modelo/estilo catedral:

- por pequenos grupos;

- com isolamento total da equipe;

- nenhum modelo beta para ser liberado antes do tempo.

Diante desse modelo "calmo e respeitoso" de desenvolvimento, o modelo Linux parecia um "grande e barulhento bazar", no qual, a todo o momento, inúmeros desenvolvedores emitiam informações sobre inovações e modificações no código compartilhando uns com os outros. Na opinião de Raymond, só mesmo uma "sucessão de milagres" poderia fazer com que essa forma de trabalhar fosse capaz de gerar um sistema coerente e estável. A mudança aconteceu a partir de um projeto bem sucedido de código livre, o Fetchmail. Esse software foi executado como um teste deliberado de algumas teorias sobre a tecnologia de programação sugerida pela experiência de compartilhamento de conhecimento do Linux. A experiência de colaboração e troca de conhecimento na rede proporcionou a Raymond a discussão "nos termos de dois estilos fundamentais diferentes de desenvolvimento, o modelo "catedral" da maior parte do mundo comercial contra o modelo "bazar" do mundo do Linux". Conforme Raymond (1999): 
Liberações novas e freqüentes são uma parte crítica do modelo de desenvolvimento do Linux. A maioria dos desenvolvedores (incluindo eu) costumava acreditar que essa era uma má política para projetos maiores que os triviais, porque versões novas são quase por definição cheias de erros e você não quer acabar com a paciência dos seus usuários. Esta crença reforçou o compromisso de todos com o estilo de desenvolvimento catedral. Se o principal objetivo era o de usuários verem menos erros quanto possível, por que então você iria somente lançar um em cada seis meses (ou freqüentemente menos), e trabalhar como um cachorro depurando entre as liberações. (RAYMOND, 1999).

Foi a necessidade de liberar cedo o código que desenvolvia para que outros pudesse depurá-lo que fez com que Raymond experimentasse a potência do conhecimento comum e das conversações em rede.

O estilo de Linus Torvalds de desenvolvimento -- libere cedo e freqüentemente, delegue tudo que você possa, esteja aberto ao ponto da promiscuidade -- veio como uma surpresa. O fato de que este estilo bazar pareceu funcionar, e funcionar bem, veio como um distinto choque. (RAYMOND, 1999).

Como proposta metodológica, Raymond fez uma inserção de seu código na rede e por meio dessa ação e do sucesso nas transformações do Fetchmail, chegou às seguintes conclusões:

"Qualquer ferramenta deve ser útil da maneira esperada, mas uma ferramenta verdadeiramente boa leva, ela própria, a usos que você nunca esperou". Ao mencionar esse fato, o autor mudou a opinião inicial sobre o processo de colaboração entre as pessoas, ressaltando o seu caráter funcional de sucesso e não de caos. Pessoas conversando e colaborando com pessoas, esse é o modo de funcionar e produzir na rede.

É preciso saber jogar o "jogo do Linus", amplificando para outras áreas do conhecimento essa ação colaborativa, através da construção do que o autor denominou por "comunidades efetivas e voluntárias de interesse". Raymond chama essa prática de movimento de cultura de "código aberto": 
Talvez no final a cultura de código aberto irá triunfar não porque a cooperação é moralmente correta ou a "proteção" do software é moralmente errada (assumindo que você acredita na última, o que não faz tanto o Linus como eu), mas simplesmente porque o mundo do software de código fechado não pode vencer uma corrida evolucionária com as comunidades de código aberto que podem colocar mais tempo hábil ordens de magnitude acima em um problema. (RAYMOND, 1999).

A experiência de Raymond é similar à metodológica desse trabalho. O objetivo é fazer uma intervenção (pesquisa-ação) no movimento do MetaReciclagem identificando as zonas de colaboração entre as pessoas, assim como inicialmente na experiência desenvolvida e aplicada por Raymond. Essa intervenção na rede do MetaReciclagem irá propor uma metareflexão de seus membros sobre as zonas de colaboração desde 2002. 


\section{A Ruptura da Metafísica Padrão}

Metafísica é uma das principais obras de Aristóteles (384-322 A.C.) abordando um ramo da filosofia para estudar a essência do mundo. Desde os primórdios da Grécia antiga, a metafísica ${ }^{18}$ estava baseada na divisão do mundo segundo as características de cada matéria e o reconhecimento espaço-temporal das formas; uma construção na qual a linguagem e nossa percepção de mundo faziam parte. Weinberger (2006) caracteriza essa construção por metafísica conteinerizada, pré-determinada.

A transformação das diversas áreas do conhecimento, inclusive a capacidade da rede em estimular e manter conversações assíncronas da representação virtual do mundo é apontado por David Weinberger no artigo intitulado The hyperlinked metaphysics of the web $b^{19}$. "A Internet continua mudando conceitos culturais, rompendo com a metafísica padrão". (WEINBERGER, 2006) ${ }^{20}$. Segundo o autor a metafísica padrão não é capaz de refletir a nossa experimentação do mundo.

Esse processo de divisão raramente é consciente e acontece através da linguagem, a qual é elaborada pelos poetas de vários tipos, incluindo cientistas, políticos, marketeiros e adolescentes revoltados (...) O modelo de containeres, como muitos de nós suspeitamos, é inadequado. Ele simplifica demais as experiências. (WEINBERGER, 2006).

A ruptura com a metafísica padrão à qual Weinberger se refere tem inspiração em Martin Heidegger (2008; 1997). Assim como as ferramentas apenas fazem

18 Metafísica: corpo de conhecimentos racionais (e não de conhecimentos revelados ou empíricos) em que se procura determinar as regras fundamentais do pensamento (aquelas de que devem decorrer o conjunto de princípios de qualquer outra ciência, e a certeza e evidência que neles reconhecemos), e que nos dá a chave do conhecimento do real, tal como este verdadeiramente é (em oposição à aparência). [Cf. ontologia.] 2.Hist. Filos. Segundo Aristóteles ( $v$. aristotelismo), estudo do ser enquanto ser e especulação em torno dos primeiros princípios e das causas primeiras do ser. Fonte: FERREIRA, A.B. de Holanda. O Novo Dicionário Aurélio da Língua Portuguesa. 3ª . Edição. Ed.Positivo, 2004.

19. WEINBERGER, David. The hyperlinked metaphysics of the web. Disponível em: http://www.hyperorg.com/misc/metaphysics/index.html Acesso em 31 mar. 2009. 
sentido quando referidas a um contexto, o mesmo acontece com a linguagem na qual os signos estão conectados àquilo a que remetem, bem como à nossa consciência do mundo em relação ao ambiente em que estamos vivendo.

A crítica de Heidegger (1997) abarca uma moderna visão de mundo na qual a concepção de sociedade nasce no indivíduo e não do grupo social. Ao considerarmos a Web como um espaço que nasce a partir da conversação e da troca entre pessoas que compartilham interesses, observa-se que ela é espaço da pluralidade social, construído, desde o início, a partir da relação, da generosidade e da atividade voluntária entre os seres humanos. Designamos kairós (kaıpós), como a concepção do tempo que se refere ao momento apropriado ou à oportunidade para que algo ainda não real, mas existindo como potência, se efetue ou aconteça.

Segundo Weinberger (2006) "O hyperlink rompe a barreira do tempo, do espaço, do idioma e do bom senso. Uma transformação mais filosófica que tecnológica". O autor entende a Web como um mundo compartilhado, que estamos construindo juntos. Weinberger (2002) apresenta um mundo não-sequencial e repleto de pedaços de informações e construções cujas narrativas nos dão o contexto da informação, independente de um centro disseminador. Esse processo de construção seria caracterizado por uma ruptura dos contêineres do tempo e do espaço. Nesse sentido, a Internet pode ser entendida como um novo lugar. Um ambiente diferente. Internet não é apenas uma nova mídia, um canal de comunicação, mas um novo lugar propício para as conversações e, como conseqüência, para uma sociedade colaborativa. O tempo (ou não tempo) da Internet é kairós.

\begin{abstract}
A Web é uma nova forma social de espaço público. Mas, por não apresentar uma geografia exata, possível de se abranger, sem espaços definidos para habitar, não podemos cometer o velho erro de tomarmos o mesmo parâmetro sobre o que, como regra, constitui a nossa sociabilidade. A Web é um espaço compartilhado onde temos a liberdade de escolher construir, alcançar e apropriar. (WEINBERGER, 2002, p. 119).
\end{abstract}

Outros pensadores da metafísica, de Platão até Nietzsche, têm refletido 
intensamente sobre o ser $^{21}$, sobre a totalidade do ser, apesar das partes que 0 formam. Heidegger percebeu que as gerações de pensadores anteriores estavam deixando de lado algo crucial, que um ser, para se caracterizar pelo que é, não pode ser definido por um outro ser $^{22}$. As singularidades tomam o lugar da completude do indivíduo. Somos partes, discretos pedaços que constituem o ser. Heidegger nos apresenta um ser - aí (dasein) (HEIDEGGER, 1997, p. 125). O conhecimento humano não é pura informação, é um conhecimento intencional, ou seja, só sabemos o que de alguma maneira nos interessou ou nos interessa. Marías (2000) comenta Heidegger e explica melhor o conceito de dansein:

Dasein é um verbo que significa existir e naturalmente é também o substantivo "existência", Dasein. A palavra Dasein se traduz, naturalmente, por existência, é a tradução normal. Mas há um momento em que Heidegger define Dasein e diz: 'Das Wesen des Daseins liegt in seiner Existenz', que se traduz literalmente: 'a essência do Dasein consiste em sua existência', (...) então traduzo: 'a essência do existir consiste em sua existência' (...) 'a essência da existência é sua existência'. (MARÍAS, 2000).

Dasein é o ser-no-mundo que se encontra em situação, num círculo de afeto e interesses; o homem que está sempre aberto para se tornar algo novo. A própria situação presente é determinada por aquilo que ele pretende fazer no futuro. Muito do que ele faz hoje, senão tudo, ele o faz em vista do que ele quer ser amanhã.

O pensamento de Heidegger (2008) nos aponta para as mudanças. Taylor Carman em sua introdução no livro Basic Writings, comentando sobre a proposta de Heidegger, menciona:

Pouco tempo depois da Segunda Guerra Mundial, Heidegger passa a acreditar que a metafísica ocidental teria ultrapassado 0 cartesianismo rumo ao subjetivismo kantiano que projeta o mundo como um "quadro" objetivo contra si mesmo. Ele começa a pensar que a moderna tecnologia não seria um instrumento ou efeito de sujeição obstinada do sujeito no mundo do qual é objeto, mas longe disso uma auto-organização menos propositiva, menos centralizada

21. Ser ou entidade: aquele ou aquilo que tem existência distinta e independente, quer real, quer concebida pelo espírito; ente, ser: Fonte: FERREIRA, A.B. de Holanda. O Novo Dicionário Aurélio da Língua Portuguesa. $3^{\mathfrak{a}}$. Edição. Ed.Positivo, 2004.

22. No original: "he had thought widely and deeply about entities, indeed the totality of entities, entities as a whole, the entirety of what is. (...) Heidegger noticed that it leaves out something crucial, namely that in virtue of which entities are entities, what makes them entities, as it were. What makes entities entidaes cannot itself be another entity". 
- portanto bem diferente - de entidades com mais recursos materiais (HEIDEGGER, 2008, p. XV).

Nesse sentido, pode-se dizer que estamos num processo de expressão de subjetividades jamais visto. Pois qualquer pessoa tem a possibilidade de publicar na rede, sejam emails, scraps, artigos, blogs, músicas, imagem ou diversos perfis em redes sociais, quantos achar necessários. A Internet é um meio multimídia que dá às pessoas espaço para inúmeras formas de expressão. A cultura cibernética não é nada mais do que uma compilação de tal diversidade.

O ser está se modificando. Cada um de nós pode ser muitos ao mesmo tempo. Basta observarmos os nicknames na Internet e o modo diferenciado como nos apresentamos uns aos outros nas inúmeras redes em que vivemos. Em algumas, somos apenas amigos dos amigos; em outras, nossa vizinhança é construída por temas e relações de interesse profissional. Ainda há outras em que somos apenas pais e mães. E outras, participamos discutindo temas cujo foco de interesse foi desenvolvido por nós em assuntos que nos envolvem pessoalmente, apenas por hobby. Entretanto, é importante pensar nessa capacidade múltipla de apresentação do ser.

A multidão, no sentido de múltiplo e não referindo-se apenas a uma soma de indivíduos, passa a estar dentro de cada um de nós. Somos, em rede, múltiplos sujeitos. Neste sentido, a Internet traz novidades. Permite perceber essas singularidades e entender que essa multidão monstruosa potencializa o debate. $\mathrm{E}$ nos faz compreender que o poder tende à descentralização. "As multiplicidades se definem pelo fora: pela linha abstrata, linha de fuga ou de desterritorialização, segundo a qual elas mudam de natureza ao se conectarem às outras." (DELEUZE; GUATTARI, 1995, p. 17). O crescimento exponencial da colaboração é uma realidade advinda da multiplicidade de interessas que compartilham informações. Está nos mutirões, nos puxadinhos, nas periferias das sociedades. A colaboração é um processo que não nasceu com o computador.

Stuart Hall (2006, p. 46) diz que o sujeito do iluminismo, visto como tendo uma identidade fixa e estável, foi descentrado resultando nas identidades abertas, 
contraditórias, inacabadas, fragmentadas do sujeito pós-moderno. As multiplicidades de singularidades formam a multidão. $O$ 'ser' deixa o centro da existência. $O$ cartesianismo, segundo Heidegger, não explica mais o nosso mundo. Está, lentamente, sendo deixado no seu lugar. O pensamento humano está em transformação. Não mais pensamos para poder existir. Aliás, como diz Murilo Mendes (apud. SODRÉ, 2002): "Só não existe o que não pode ser imaginado".

Internet não tem nada a ver com computadores. Tem a ver com pessoas. Por isso, o recorte que queremos abordar está na compreensão do espaço virtual. A esse respeito diz Pierre Lévy (2001):

A virtualidade não tem absolutamente nada a ver com aquilo que a televisão mostra sobre ela. Não se trata de modo algum de um mundo falso ou imaginário. Ao contrário, a virtualização é a dinâmica mesma do mundo comum, é aquilo através do qual compartilhamos uma realidade. (LÉVY, 2001, p. 148).

Virtual é uma palavra mal compreendida. O virtual do qual a maioria das pessoas fala não é algo etéreo, não é um lugar que as pessoas se utilizam para nãoser o que são. O virtual é parte do que chamamos de real, é tão real como o presencial. Virtual tem raiz no latim: vir refere-se a homem, força, virilidade, virtude. E, dessa forma, virtual é potência. Faz oposição ao atual, ao presencial. É um espaço de significado simbólico. Um espaço informacional que representa uma nova geração de sistemas de comunicação.

Essa analogia permite pensar a rede como um espaço onde a potência é mais sugestiva e operativa que o poder. Explica- se, assim, a característica rizomática do espaço informacional da qual tratam Deleuze e Guattari (1995) e que opera novas formas de relação na sociedade. Conhecimento livre, copyleft ${ }^{23}$, contracultura, anarquia, colaboração são os bons resultados dessa equação. Os

23 O copyleft surge a partir do início de uma proposta de software livre em 1984 quando Richard Stallman, no Massachusetts Institute of Technology, por convicções políticas dedicou-se a trabalhar em um projeto nãoproprietário de desenvolvimento de um sistema operacional livre ao qual denominou GNU (GNU's Not Unix). Seu ideal era criar um software que permitisse às pessoas o uso livre da informação sem que tivessem que pedir permissão para transformar o código de acordo com suas necessidades, ou quando quisessem compartilhar com os amigos. Entretanto, as características de liberdade para compartilhar e customizar eram incompatíveis com o modo de produção do mercado e com as leis de direitos autorais. Tal realidade exigiu a criação de uma licença que liberasse os usuários para copiar, distribuir e modificar o material produzido. Daí surgiu a primeira licença copyleft GNU General Public Licence (GPL). Disponível em:< http://pt.wikipedia.org/wiki/Richard Matthew Stallman> Acesso em: 18 maio 2009. 
meios de translação, de comunicação, de interação, no sentido de que nos possibilitam o trânsito, o viver entre idéias, culturas, informação e conhecimento diversos.

Desde o século XIX, grande parte do esforço científico tem sido aplicada ao desenvolvimento de meios de translação e comunicação, ou seja, a novas formas de conectar pessoas. Carros, aviões, rádio e televisão, de certa forma, encurtam a distância entre os seres humanos e, ao mesmo tempo, se constituem em poderosos instrumentos estratégicos pelos quais circulam idéias e modos de vida.

No séc. XXI a Internet segue nesta mesma linha: serve para conectar pessoas, idéias, modos de vida e produção social. Weinberger (2004) denomina esse esforço como a era da conexão, embora outros termos pareçam descrever igualmente estes tempos marcados pela comunicação, informação, conexão. Em relação aos demais meios de comunicação e informação, a Internet é mais abrangente. Ela não apenas aproxima as pessoas. Ela cria um novo lugar de convivência. A Internet é um mundo diferente daquele no qual crescemos. Tempo e espaço não têm o mesmo significado que aprendemos nas experiências comuns ou mesmo com os demais meios de comunicação. O meio físico caminha para a virtualidade. O paradoxo, assim, se transforma em paradigma. Elizabeth Saad (2003) menciona:

\footnotetext{
Aspectos mais significativos das redes digitais de comunicação e informação: (...) coloca produtor e receptor da informação no mesmo patamar; que possibilita diálogos interpessoais e intergrupais sem a intervenção do produtor da informação; com potencial de uso não apenas de distribuição e captação de informações, mas também de gerenciador de dados e criador de sentido para grupos de usuários de qualquer porte. (SAAD, 2003, p. 25-26).
}

Sem meios de acesso ficaremos marginais à sociedade atual. Democracias interconectadas, para existir, precisam de acesso irrestrito que as garantam enquanto tais. A tendência é de que haja convergência de tecnologias, no sentido de operar a passagem entre a tecnologia anterior para a digitalidade da rede. Telefones conversam com a rede, enviando e recebendo informações. Televisões devem fazer o mesmo. Os portáveis, incluindo celulares estão conectados em rede, propiciando 
aos usuários um mundo onde seja possível aceder às informações e "bloggar" suas análises, retroalimentando a rede.

O que significam os avanços e o acesso às tecnologias de informação e comunicação? Os avanços significam simplesmente o barateamento e massificação da tecnologia. Assim, a grande sacada está em dar vazão a essa conectividade. Buscar o potencial para incrementar o inter-relacionamento dos mercados, ou "bazares”, para usar o termo de Eric Raymond (1999), enquanto mediações entre pessoas, produção, produtos e signos.

Por trás de cada computador há um ser humano buscando uma nova forma de aprender, produzir, se expressar, ensinar, aproveitar e prosperar. E humanos são também sonhos, sentimentos e contradições, não apenas razão, cérebro e máquina, mas uma rede de crenças e desejos. Uma vez que dentro de nós há multidões e que podemos ser símbolos ou signos, hoje podemos dizer que somos links. Links que se conectam com outros links para trazer à tona um mundo mais compartilhado de diferentes realidades. 


\section{A Cultura das Redes}

A sociedade e a rede são conceitos indissociáveis. Os seres humanos vêm se organizando em redes colaborativas desde o começo dos tempos. Há muito esse tipo de organização permite que sejamos capazes de transformar o mundo ao nosso redor criando conhecimento e cultura de maneira coletiva. Não há sociedade, se não houver redes seja de amigos, famílias, primos e primas, sobrinhos por pessoas com afinidades que se conectam por um algum fator que combina os anseios, interesses e desejos das pessoas.

Entretanto se a Era Industrial, sob o domínio da comunicação de massas, deixou a rede escondida, em segundo plano, a Internet tem nos levado a reviver a idéia. O sistema tornou-se mais abrangente. As redes de amigos cresceram. Hoje em dia, com o advento e popularização da Internet, novas redes colaborativas, e voltadas para a produção criativa, têm surgido com incrível velocidade, gerando bens coletivos de valor inestimável.

Quando acessamos nossos computadores e tudo corre bem, abrimos o navegador para o mundo. Atingimos o mais abrangente espaço hacker - 0 das pessoas conectadas - onde a troca de informações facilita o aprendizado informal. A distância entre as pessoas diminui. A conexão transmuta-se em uma outra realidade.

A emergência é um processo de auto-organização, cuja única "única diferença é o material de que são feitas: células de enxames, calçadas, zeros e uns". (JOHNSON, 2001). Entretanto, isso não é tão importante, pois o que nos interessa é observar a tendência do pensamento de baixo para cima (bottom up) modificando a forma de agir da humanidade. Continuamente, ouvimos falar das experiências de organização de comunidades de seres vivos, da capacidade de construção de redes descentralizadas de formigas, cupins ou abelhas.

Mutação, transformação e modificação são palavras que usamos bastante no cotidiano digital. Se a Internet trouxe em seu bojo a idéia de revolução, trouxe 
consigo críticas inequívocas em relação ao modo como a sociedade moderna estava estruturada. Romper com os paradigmas significa destruir os preconceitos nos quais estamos inseridos. E muitos desses preconceitos estão diretamente ligados à forma como nos organizamos e conversamos, ainda que esse processo ocorra de forma sutil, sem nos darmos conta, sem exatamente compreendermos porque agimos de determinada maneira.

De acordo com Henry Jenkins (2007), no artigo From YouTube to YouNiversity:

A cultura da rede conectada possibilita uma nova forma de poder de baixo para cima, pois diversos grupos de pessoas dispersas se associam de acordo com suas habilidades e encontram soluções de muitos problemas complexos que talvez não pudessem resolver individualmente. Eles são capazes de fazer isso devido à maneira como as novas plataformas das novas mídias dão suporte para a emergência de redes sociais temporárias que existem apenas durante 0 tempo necessário para fazer face a desafios específicos ou responder as necessidades imediatas de seus membros. (JENKINS, 2007).

Esses encontros em rede, essa conversação, com que as pessoas se aproximem não só para trocar informações cotidianas, muitas vezes descartáveis, mas para uma auto-organização da sociedade civil. As conversações seriam a democratização do processo organizacional coletivo?

Henry Jenkins (2007) chama essa cultura de participatória, a saber:

(...) cultura participatória, para descrever os novos tipos de atividades sociais e criativas que emergiram em associações na rede. Uma cultura participatória é uma cultura que conta relativamente com poucas barreiras à expressão artística e ao engajamento cívico e dá um grande apoio para se criar e para compartilhar criações de qualquer pessoa ou de um parceiro que seja uma espécie de mentor (...) Uma cultura participativa é igualmente aquela em que os membros confiam no conteúdo material de suas contribuições e sentem algum nível de conexão social uns com os outros. A cultura participatória desloca o foco da capacidade de uma expressão individual para envolver toda a comunidade. (JENKINS, 2007). 
Em rede ninguém realmente pensa sozinho. Trata-se da morte do pensamento individualista. Todo pensamento é produzido em colaboração com o pensamento passado e presente, com os pensamentos uns dos outros - cada nova idéia e imagem convidam a novas colaborações e as inauguram. Ao tratar dos aspectos econômicos da produção social, em particular do fenômeno da produção pelos pares, commons based peer production, Benkler (2006, p. 91) aponta três questões importantes: I) Por que as pessoas participam? II) Por que participam em um mesmo momento e em um mesmo projeto? III) É eficiente que todas essas pessoas compartilhem seus computadores e doando seu tempo e esforço criativo?

A resposta para essas perguntas tem como exemplo de ação a produção contemporânea do sistema operacional Linux. De acordo com o autor a motivação para participar em uma produção colaborativa não vem apenas da intenção de se fazer uma boa ação, mas de complexos relacionamentos que agregam valor tanto ao trabalho quanto à participação em si, seja status, seja reputação, seja dinheiro e demais valores subjetivos para os participantes para além do projeto. Em suma, crenças e desejos estão envolvidos na participação, motivos intrínsecos e extrínsecos. "Vivemos nossas vidas em diferentes camadas sociais, e o dinheiro tem uma relação complexa com cada uma delas, algumas vezes ele motiva a participação das pessoas, algumas vezes ele desmotiva." (BENKLER, 2006, p. 92).

David Weinberger (2006) analisa essa participação sob a perspectiva de uma outra democracia:

Não é óbvio que, apenas por estarmos participando mais de nossa cultura, nossa democracia também mude. Certamente política e cultura não são reinos distintos, temos então a expectativa de que uma deva afetar a outra. Todavia isso não ocorre necessariamente. Tomemos alguns exemplos de participação cultural. O que você escolheria? Wikipédia? Blogosfera? Compartilhamento de arquivos? Second Life? Delicious.com? AssignmentZero? Qual a sua participação neles e o que essa participação nos ensina? Até que ponto trata-se de fazer política? As lições são repassadas? Por exemplo: a Wikipédia nos ensina - mas há aqueles, porém, que pensam nisso com reservas - que as autoridades credenciadas podem não ser as únicas pessoas em quem devemos confiar. Mas isso também se aplica à elaboração das enciclopédias? Isso não afetaria nossa visão de, digamos, especialistas em políticas do governo? O que 
estamos aprendendo e onde isso se aplica? (WEINBERGER, $\left.2006^{24}\right)$.

São muitas formas de se participar da rede. David Weinberger (2006) pergunta se todas essas interfaces de conexão vão causar algum impacto nas pessoas que estão estabelecendo novos campos de força por meio de discursos, que se apresentam sob múltiplas interfaces, e emergem dinamicamente nos movimentos. Uma condição de sobrevivência imersa que cria espaços para as ações múltiplas, nas quais o discurso linka e constrói.

O desafio é entender a rede como um movimento múltiplo, no qual a incerteza é uma característica mais acentuada do que os formatos, as disposições, e, principalmente, as ferramentas pelas quais o próprio movimento se manifesta. Quando se fala em formas de organização da rede, o parâmetro é a alta complexidade, na qual as fronteiras não estão claramente estabelecidas e onde domínios surgem e desaparecem. Pode-se pensar no movimento de uns em relação ao movimento de outros. Contudo, além disso, as pessoas têm uma meta.

A rede dos hackers, um dos exemplos mais evidentes que produz, todos os dias, inovações tecnológicas revolucionando a economia dominante do mercado de software. São os chamados softwares livres, que podem ser instalados gratuitamente em qualquer computador, permitindo a realização de uma gama enorme de atividades, desde conectar a câmera digital até editar e mixar uma música. Mas o mais importante é que estes softwares são compartilhados nessas redes, podendo ser estudados, pesquisados e aperfeiçoados por todos.

Todavia a produção coletiva e descentralizada de bens criativos não se aplica somente ao software. Já começam a aparecer reflexos dessa nova forma de produção em diversas áreas do conhecimento. Um ótimo exemplo é a Wikipédia, uma enciclopédia construída coletivamente na web. O software livre é o caso mais

\footnotetext{
${ }^{24}$ Referência extraída de texto da Internet: http://www.hyperorg.com/misc/metaphysics/ Acesso em: 31 março de 2009.
} 
conhecido e mais impactante de uma nova dinâmica que demonstra a produção de conhecimento livre como alternativa economicamente viável e sustentável.

Pretendemos discutir o surgimento das novas redes, o papel da Internet e da tecnologia digital como multiplicadores, e os impactos sociais, culturais e econômicos deste novo meio de produção criativa. Conforme Foucault (2005) não há saber que não seja acompanhado de uma forma de poder. Para contextualizar precisamos pensar no fato de que a equação poder/saber esteve desbalanceada numa entropia negativa durante muito tempo. A equação estaria melhor nestes termos: assim como o saber só existe quando está livre, conhecimento livre pressupõe o desatrelamento do poder. Pensamos aqui numa estratégia de poder saber descentralizadora que se encontra nas mãos da multidão por meio da apropriação das ferramentas de comunicação. Contrapondo à idéia do homem permeado pela política neoliberal com uma iniciativa individual e empreendedora, demonstrada nos anos 70 por Foucault (2008, p. 331), a concepção nascida do neoliberalismo de homo oeconomicus e as múltiplas interfaces dos indivíduos e a relação como uma relação econômica em diversos âmbitos, donde se coloca que todo sujeito é um homem econômico e busca seus interesses. Uma visão individualista e utilitária das ações sociais. Hoje o novo conceito de homos oeconomicus pressupõe uma lógica daquele que compartilha o conhecimento em rede para buscar seus próprios interesses e que, para defendê-los precisa construir, investir em ações colaborativas ou agir de maneira colaborativa.

O que queremos dizer é que a rede indica um futuro libertador. A Web só faz sentido quando um se preocupa com o outro. Numa circulação generalizada e libertadora de fluxos de informações e das ondas econômicas. A Web é um mundo que criamos para todos nós e só pode ser compreendido no interior de uma teia de idéias que inclua os pensamentos que fundamentam a nossa cultura, com o espírito humano persistindo.

Howard Rheingold (2003) autor do livro Smart Mobs: the next social revolution, diz que o potencial transformador mais profundo de conectar as inclinações humano-sociais à eficiência das tecnologias da informação é a 
possibilidade de fazer coisas novas conjuntamente, e o potencial para cooperar numa escala e de maneiras nunca antes possíveis. Além disso, as multidões inteligentes (smart mobs) emergem quando a comunicação e as tecnologias da computação amplificam o talento humano para a cooperação.

As redes da mobilização englobam a rede do conhecimento. São mais factíveis, reais e mostram resultados rápidos. A sociedade civil se organiza, compra, vende, troca, aprende e ensina mobilizando as bases para o interesse comum. Desenvolver a comunidade, criar filhos, conviver com amigos, trabalhar e tentar ser feliz. Dizemos que estando em rede não há mais necessidade de operar a mudança social, ela se faz permanente.

Uma nova dinâmica, que demonstra a produção de conhecimento livre como alternativa economicamente viável e sustentável. O código aberto está trazendo para a inovação o que a linha de montagem trouxe para a produção em massa.

Quando pensamos em redes hiperconectadas e suas diversas formas de organização, temos que nos atentar para a maneira que as comunidades de software livre se desenvolveram. O conceito de software livre começa a ser disseminado por Richard Stallman na década de 1970: um conceito ideológicofilosófico que desponta no interior das universidades americanas. No entanto, o ritmo de desenvolvimento e de produção do software livre estava nas mãos de alguns poucos desenvolvedores.

O Linux inaugura uma abertura, só possível graças às possibilidades de compartilhamento e trocas promovidas pelas novas tecnologias de informação e comunicação. A Internet deu condições para que as trocas fossem incrementadas, o que até então não era possível. Linus inaugurou um modo de produção que contava com a colaboração das pessoas comuns.

Colaboração como capital social. Colaboração para fazer qualquer coisa que o desejo provoque. Colaboração como condição de sobrevivência. Colaboração como viés estrutural no desenvolvimento das novas organizações, veia latente dos processos de inovação tecnológica, canal de viabilização da interação entre 
fornecedores, clientes e comunidades de usuários dos múltiplos produtos hoje oferecidos pela Internet.

Colaboração é processo, e é preciso que aconteça independente do retorno financeiro a curto prazo. É esta a grande novidade, onde a colaboração passa a ter um papel mais importante do que a catedral. O conhecimento tende a ser livre. Estamos presenciando intensas mudanças, principalmente no que se refere a propriedade intelectual, liberdade de expressão e práticas de comunicação. Prefiro usar o termo linkania ao invés de cidadania, porque este último se relaciona a cidade ou expressa o que definimos como metafísica padrão. Linkania entra no contexto de ruptura e da percepção que nós somos links ligados a outros links. A hiper-conexão não faz muito sentido se não pensarmos em comunidade, ou em multidão, servindonos do conceito de Negri e Hardt (2000). Nós somos a rede. 


\section{As Zonas de Colaboração}

Uma cultura de rede traz a reboque uma nova forma de organização descentralizada, tanto do ponto de vista da organização per si como da comunicação mediada pela tecnologia hiperconectada. Essa cultura de rede se expande rapidamente. Pessoas comuns se apropriam dessas tecnologias e reverberam em suas comunidades aquilo que aprenderam. A replicação é a forma pela qual as pessoas se valem para aprender e ensinar nesse novo paradigma informacional.

As tecnologias da informação e comunicação são o cenário lógico para a expansão das Zonas de Colaboração como um meio de produção. No contexto da formação de uma nova geração de comunicadores que, ao contrário das anteriores, se constitui de forma independente dos grandes meios de comunicação e tem nas ferramentas de edição na Internet, os blogs, seu meio de criação, difusão e troca de informação e conhecimento.

O que é colaboração? Essa é uma pergunta que fica sem resposta. Urge tentar discorrer sobre o assunto sem tocar na definição. Falar do que nos move. Não daquilo que é. Da relação entre as pessoas e não da coisa em si. Participamos da vida social. A colaboração como princípio de sobrevivência, como essência inerente do próprio ser humano. Um ser gregário, social, incapaz de viver sozinho. Daí a impossibilidade de se dissociar colaboração e interação das pessoas, de grupos, em torno de algo comum.

Colaboração não tem um significado estanque, pois acontece na ação. Pressupõe generosidade, que é limitada, parcial. Inconstante que é, supera diversidades, une e aproxima os diferentes. É fraterna, levando as ações a acontecerem não obrigatoriamente quando há necessidade. É competitiva quando nos apropriamos da tecnologia e colaboramos como uma forma de alcançarmos reputação dentro de um determinado grupo de pessoas. É uma lógica que não se 
mantém no cotidiano. Apresenta uma dinâmica caótica da relação do ser em comunidade.

Do ponto de vista de uma sociedade em rede, a produção cultural está sendo catalisada pela colaboração. Pessoas têm muito mais possibilidades de experimentação e realização de projetos. Foi no início dos anos 90, que Linus Torvalds, influenciado pelas idéias de Stallman, disponibilizou os códigos na rede. Essa história tornou-se conhecida. O Linux explodiu na rede da moçada e extrapolou limites geográficos. Milhares de programadores colaboram frequentemente com 0 software. Outros muitos milhares cooperam com outras comunidades.

Da mesma forma que buscamos um modelo de desenvolvimento de software, alavancamos os aspectos de colaboração, de liberdade, de apropriação e replicação para a área do conhecimento. Surge, assim, uma comunidade de pessoas em rede que comungam por uma ética e uma cultura próprias, baseadas no compartilhamento do conhecimento e na ausência de hierarquias - verticalização dos processos. Essa comunidade clama por liberdade, por meio das iniciativas de produção de conhecimento em rede. Aliás, a sacada do Linus foi usar a internet para compartilhar o desenvolvimento de uma idéia. Não é à toa que o Linux aconteceu na mesma época da Internet. Emerge um modelo de produção colaborativa em rede.

A rede é potencializada pela Internet. É assíncrona; o tempo não para. O tempo flui numa complexidade caótica. O caos assusta também. Porque nos faz pensar, deixando-nos fragilizados frente à falta de controle que temos ou não das 'coisas'. Esse tempo assíncrono é uma ruptura. Assim como o ser que se redescobre esquizofrênico; assim como o espaço informacional que desconhece barreiras de ir e vir; assim como o conhecimento que se dobra, e liberta-se. $O$ crescimento dessa rede é rizomático, distribuído e veloz. Não é organizado. Mas quem disse que seria organizado? O conhecimento é recombinante. Um dispositivo que se dá no remix. Tudo se transforma, nada se cria. A recombinação se dá na colaboração. 
Essa forma de desorganização em rede é capaz de criar espaços que se configuram como TAZ (zona autônoma temporária) “(...) a TAZ é uma intensificação, um excesso, uma abundância (...) a vida vivida em bez de sobrevivida (...)".(BEY, 2001, 36)

Por uma característica de sua própria natureza, a TAZ faz uso de qualquer meio disponível para concretizar-se - pode ganhar vida tanto numa caverna quanto numa cidade espacial - mas, acima de tudo, ela vai viver, agora, ou o quanto antes, sob qualquer forma, seja ela suspeira ou desorganizada. Espontaneamente, sem preocupar-se com ideologias ou anti-ideologias. Ela vai fazer uso do computador porque o computador existe (...). (BEY, 2001, p. 36).

Um dispositivo que dá visibilidade da articulação em rede para a transformação social. De certa forma, com a cultura hacker a produção tende ao infinitesimal (in)finito. O inteiro que contempla toda a multiplicidade. Colaboração aponta para uma teoria social que contenha o princípio da continuidade. A continuidade da ação comum. Um processo recursivo onde duas ou mais pessoas ou organização trabalhem juntas para uma interação de objetivos comuns.

\begin{abstract}
Seja através de uma simples pirataria de dados, ou do desenvolvimento de formas mais complexas de relacionamento com o caos, o hacker da web, o cibernauta da TAZ encontrará maneiras de aproveitar as perturbações, quedas e breakdowns da net (maneiras de gerar informação a partir da 'entropia'). O hacker da TAZ trabalhará para a evolução de conexões fractais clandestinas como um rastreador de fragmentos de informações, um contrabandista, um chantagista, talvez até mesmo como um ciberterrorista. Estas conexões e as diferentes informações que fluem entre elas e por elas, formarão as "válvulas do poder" para a emergência da própria TAZ (...). (BEY, 2001, p. 38)
\end{abstract}

Podemos dizer, de certa forma, que o surgimento ou a apropriação de Tazes são indícios de Zonas de Colaboração. Projetos como o desenvolvimento de softwares livres estão apoiados no fenômeno da emergência das Zonas de Colaboração. Na afirmação que os espaços informacionais contemplam comunidades, softwares sociais, ferramentas de conversação e comunicação. Esses espaços são ocupados por uma conversação assíncrona que emerge na rede ao ponto de provocar rupturas na cultura de massa. 
Com as tecnologias da comunicação e da interação, as redes passam a facilitar a convivência à distância em tempo real. Provocam e potencializam a conversação. Reconduzem a comunicação para uma lógica de sistemas organizacionais capazes de reunir sujeitos e instituições de forma descentralizada e participativa. Reorientam fluxos criativos e abrem novas possibilidades de circulação da riqueza.

A tecnologia se distende e possibilita incrementar a inteligência das pessoas. A revolução das tecnologias da informação atua remodelando as bases materiais da sociedade e induzindo a emergência de agenciamentos colaborativos como base de sustentação social. Não podemos atribuir tais mudanças apenas à tecnologia. $A$ Internet torna possível o florescimento de novos movimentos sociais e culturais em rede. Possibilita organizar a sociedade civil em novas formas de gestão e retornar às redes humanas depois de um longo período de domínio das redes de máquinas e da burocracia. "A TAZ está interessada em resultados, ataques com êxito à realidade consensual, conquistas de patamares de vida mais altos e intensos." (BEY, 2001, p. 42). No limite da ruptura dos paradigmas, a colaboração aparece como um potencializador das energias produtivas. A sociedade está se tornando mais aberta e de uma forma ampla, mais colaborativa.

Tais trocas tem se tornado fonte de inovação e criatividade e exigido mudanças nas leis de copyright estabelecidas no início do sec. XX para dar lugar a formas alternativas de copylefts que permitam o uso inteligente da cultura produzida por muitos em prol de uma disseminação do conhecimento. Discussões em torno do assunto emergem da necessidade de novas regras de acordo com Lessig (2008, p. 30) que busquem responder a questões como: "o que significa para a sociedade quando toda uma geração cresce sendo considerada criminosa por seus hábitos de troca de conhecimentos?" Que soluções podemos dar a essa geração para que ela não seja considerada criminosa de acordo com práticas e leis que defendiam a indústria e a produção cultural.

Artistas e autores precisam de incentivo para criar. Nós podemos criar um sistema que faz exatamente isso sem fazer com que nossas crianças se transformem em criminosas. A última década está repleta de trabalhos extraordinários feitos 
por alguns dos melhores acadêmicos da América nos quais realizam o mapeamento e o esboço de formas alternativas para o sistema de copyright existente. Tais alternativas deveriam ter como meta as mesmas finalidades que o copyright segue, sem tornar criminosos aqueles que naturalmente fazem o que as novas tecnologias os encorajam a fazer. (LESSIG, 2008, p. xix).

Pensar aspectos alternativos para uma prática de apropriação da tecnologia social que já se tornou comum, tal como recombinações, remix ou sample, é considerar que a vida está mudando. Vivemos em um gap geracional que emerge do uso das tecnologias da informação, entretanto é possível perceber que se trata de uma mudança sem volta como apontam algumas pesquisas que tratam de juventude, novas mídias e aprendizagem. Aspectos de ruptura com o cotidiano espacial e temporal, principalmente com as condições geográficas em que se vive e novas construções culturais a partir do compartilhamento em rede são característica da geração always on. Danah Boyd (2008, p. 146) em Taken Out Of Context, pesquisa realizada com adolescentes americanos, traça o perfil e o comportamento da geração que troca conhecimento nas redes sociais. A autora relata que o hábito de utilizar redes sociais ${ }^{5}$ e tornar a vida pública, se expor e "conhecer os amigos dos amigos", traz consigo a potência de uma maior democratização da realidade social. Não importa o conteúdo da conversa dessa nova geração, o diferencial é que estão conectados o tempo todo, conversando e trocando idéias. Por meio dessa intensa conversação é que se encontram expostos a possibilidades de intervenções na realidade social. Dessa condição primordial que os nativos digitais desfrutam, bem ou mal, ocupam um espaço que antes era reservado apenas aos grandes veículos de comunicação.

Essa questão implica em uma ética que é permeada pela relação. Se pensarmos nos processos educativos estabelecidos pela escola que ainda defendem a conteinerização do conhecimento e formas denominadas - "certas" - ou - "erradas" - de aprender, desprezaremos a atual sociedade que aprende por meio das novas mídias. Em recente pesquisa de ITO et. al. (2008) intitulada Living and Learning with new media relata que os jovens estão cada vez mais autônomos em sua aprendizagem apesar de frequentarem a escola normalmente. Essa liberdade 
de aprender e acessar qualquer tipo de conteúdo disponibilizado na rede é que faz a diferença na produção da nova geração. Liberdade em relação ao acesso à organização do conteúdo segundo critérios de relevância e valores atribuídos pelos usuários (tais como as folksonomias) aos conteúdos e às demais opiniões de outros usuários que são compartilhados através de sistemas como o del.icio.us, Digg, Bloglines e outros agregadores de informações são sinais de uma geração que não fica em silêncio, mas que ocupa espaços de maneira mais livre e independente da opinião formada pelos grandes veículos de comunicação.

\subsection{As Redes São Por Demais Reais}

Redes sempre tiveram o poder de produção de subjetividade e pensamento. Heidegger (1968, p. 35) pergunta: "O que é pensar?" E, responde: "Nós nunca chegamos aos pensamentos eles vêm a nós". É a hora conveniente para a conversação. Isto nos dispõe para a meditação em comum, esta nem considera o opinar contraditório, nem tolera o concordar condescendente. $O$ pensar permanece firme ao vento da coisa. De uma tal maneira de conviver, talvez alguns surjam como companheiros no oficio do pensar, a fim de que inesperadamente um deles se torne mestre. Pensar em rede não é apenas pensar na rede, que ainda remete à idéia de social ou a idéia de sistema, sobretudo pensar a comunicação como lugar da inovação e do acontecimento, daquilo que escapa ao pensamento da representação.

Para Deleuze (1985, p. 124) pensar é experimentar, é problematizar. O saber, o poder e o si são a tripla raiz de uma problematização do pensamento. E, primeiramente, considerando-se o saber como problema, pensar é ver e é falar, mas pensar se faz no entremeio, no interstício ou na disjunção do ver e do falar. É, a cada vez, inventar o entrelaçamento, lançar uma flecha de um contra o alvo do outro, fazer brilhar um clarão de luz nas palavras, fazer ouvir um grito nas coisas visíveis. Pensar é fazer com que o ver atinja seu limite próprio, e o falar atinja o seu, de tal forma que os dois estejam no limite comum que os relaciona um ao outro separando-os. 
A rede apresenta dois lados, um voltado para a construção de modelos que constituem como totalidades das relações imanentes e outro para a singularidade e paisagens irredutíveis. A sociedade, o capital, o mercado, o trabalho, a arte, a guerra são hoje, definidos em termos de rede. "O fato de que pensar é pensar em rede". (PARENTE, 2004, p. 106). Segundo o autor, de fato, máquinas infocomunicacionais estariam engendrando profundas transformações nos dispositivos de produção das subjetividades. Vivemos um tempo de mudanças. A relação é paradoxal. A mistura, a miscigenação cultural resulta num processo de enriquecimento e empobrecimento, singularização e massificação, desterritorilização e reterritorialização, potencialização e despotencialização da subjetividade em todas as dimensões.

\subsection{Tecnologia Maquínica}

Guattari (2006, p. 50) em Caosmose, denomina maquínico o estrato de sentido formado por matérias expressivas heterogêneas, não linguisticamente formadas, mas ainda assim de natureza semiótica. Substâncias de expressão heterogêneas como as codificações biológicas ou as formas de organização própria ao socius - como aquelas derivadas de instituições como a família ou a escola atravessam, transversalmente, os domínios de sentido propriamente linguísticos.

Para Guattari (2006), a informática e a tecnociência não são nada mais do que formas hiperdesenvolvidas da própria subjetividade. Aqui entram fatores subjetivos das atualidades históricas (componentes semiológicos significantes que se manifestam através da família, educação, esporte, cultura, meio-ambiente, arte e religião,) o desenvolvimento em escala das produções maquínicas de subjetividade (elementos fabricados pela indústria das mídias, cinema, máquinas linguísticas etc.) e, por último, os aspectos etológicos e ecológicos relativos à subjetividade humana, a ecologia social e a ecologia mental. E, são trabalhados por agenciamentos coletivos de enunciação.

De acordo com Deleuze (1994) uma máquina que não fosse investida de desejo e alimentada de subjetividade seria um corpo sem vida. Todo corpo tem sua 
artificialidade e toda máquina tem sua virtualidade. A tecnologia é, portanto, a prótese. É o corpo sem órgãos que, para Deleuze, é como o mecânico supõe uma máquina social. O próprio organismo supõe um corpo sem órgãos definido por suas linhas, seus eixos e seus gradientes. Todo um funcionamento maquínico distinto das funções orgânicas sociais tanto quanto das relações mecânicas.

Nesse contexto, podemos perceber que é a primeira vez na história da humanidade que a realidade do aqui e agora se encontra imersa nas tramas de uma temporalidade maquínica. A tecnologia como fato cultural multitemporal. Heidegger (1997, p. 125) diz que a do tempo só se tornava plenamente visível, quando o tempo sem fim se explicitava, em contraposição a algo. Vivemos, então, nesta contraposição. E assim, percebemos a desconteneirização não só do tempo, mas do espaço, do ser e do conhecimento. Serres (apud. Parente op. cit.) diz que o tempo multitemporal passa e não passa: ele percola. Para Serres, o tempo funciona como um filtro, que ora faz passar, ora impede a passagem. É desta forma que as tecnologias remetem ao duplo movimento de aceleração e desaceleração, inovação e tradição, desterritorialização e territorialização. A contemporaneidade se caracteriza cada vez mais pela edição ou a forma como as partes do sistema são montadas ou articuladas. Esta é a cultura do remix.

E, nesse movimento remixado, misturado e miscigenado, uma cultura que se desenvolve em rede exige o reconhecimento por parte da consciência. A partir de então, a filosofia ficou diferente, não pôde mais ignorar o estar-com-os-outros; não se pode ignorar as relações em rede.

São diferentes os percursos para cada indivíduo. Diferentes, portanto, a forma como cada um pode perceber onde vive, como vive e escolher o que fazem com seu tempo. Se somarmos todos os percursos, teremos reconstituído uma pluralidade de mundos dentro de um mesmo e único mundo. 


\subsection{Produção de Subjetividade}

A subjetividade é como a cognição, o advento, a emergência de um afeto e de um mundo a partir de suas ações no mundo. É a realidade psíquica, emocional e cognitiva do ser humano, passível de manifestar-se simultaneamente nos âmbitos individual e no coletivo, e comprometida com a apropriação intelectual dos objetos externos. O campo conceitual de subjetivação surge no trabalho de Foucault e é retomado por Deleuze e Guattari. A subjetividade é engendrada, produzida, pelas redes e campos de força social.

Um dos conceitos de subjetividade nos é dado, "ainda que provisoriamente", por Guattari (2006), ao dizer que:

\footnotetext{
Por subjetividade entendemos um conjunto de condições que torna possível que instâncias individuantes e/ou coletivas estejam em posição de emergir como território existencial auto-referencial em adjacência ou em relação com uma alteridade ela mesma subjetiva. (GUATTARI, 2006, p.19).
}

A subjetividade, de fato é plural, polifônica, para retomar uma expressão de Mikhail Bakhtin, que Deleuze cita em várias partes de sua obra. O que importa não é unicamente o confronto com uma nova matéria de expressão. É a constituição de complexos de subjetivação - indivíduo-grupo-máquina-trocas múltiplas - que oferecem às pessoas possibilidades diversificadas de recompor uma corporeidade existencial, de sair de seus impasses repetitivos e de, alguma forma, se ressingularizar.

Desta perspectiva, século XXI exige, portanto, modificações estruturais no poder para atender à nascente sociedade informacional. É nesse cenário que as redes sociais adquirem importância, pois em seu elemento constitutivo trazem uma nova possibilidade organizacional, logo, estrutural dos fluxos de conversação e da forma como o poder é exercido a partir dos relacionamentos nas redes.

Deleuze (1978) em Le cours de Guilles Deleuze sur Spinoza diz que uma única substância possuindo todos os atributos e cujos produtos são os modos, as maneiras de ser. Desde então, se eles são as maneiras de ser da substância que possui todos os atributos, esses modos existem nos atributos da substância. Eles 
estão compreendidos nos atributos. Tarde (2007) faz uma aproximação de Leibniz e Espinosa. Ele faz um link entre a idéia de mônadas e substância em Espinosa. No entanto, Deleuze ao falar dos atributos da substância, de certa forma, aponta para as diversas qualidades ou à multiplicidade. Logo, isso me faz pensar nos modos que essas substâncias se relacionam. O afeto, ou melhor, aquilo que nos afeta é um conceito de Espinosa. Somos afetados por boas ou más relações, logo, temos diferentes composições com os ambientes e com pessoas na medida que somos afetados de diferentes modos. Sobre o agenciamento a partir dos afetos, Vargas menciona no prefácio de Monadologia e sociologia (TARDE, 2007, p. 37-38).

Enfim, se as mônadas são meios universais é porque não há agência sem outrem, não há existência fora da relação, não há relação sem diferença. Logo, se a sociedade é a possessão recíproca de todos por cada um é porque os processos de composição social não se realizam independente das micropolíticas da possessão que os constituem enquanto tais e que, portanto, Ihes são imanentes. (TARDE, 2007, p. 37-38).

$\mathrm{Na}$ construção de um espaço comum para a produção, a Web - cujos movimentos somos responsáveis através dos interesses compartilhados - tem transformado o mundo. Falar on-line é publicar e publicar on-line é estar conectado (SHIRKY, 2008, p. 171). Esse discurso conectado pode alcançar um público amplo e por meio dele a inovação e o poder. Falar na Internet é também sobreviver.

A rede sociotécnica de grande complexidade é composta da riqueza dos nossos sentidos e faculdades, como também dos objetos, suportes, dispositivos e tecnologias. O importante é pensar não na tecnologia em si, como prótese ou extensão, mas como um processo contínuo de delegação e distribuição das atividades cognitivas que formam uma rede com os diversos dispositivos não humanos. Em outras palavras, uma rede de aprendizado, de circulação da informação.

A informação permite resolver de forma prática - por meio de operações de seleção, de extração, de redução e de inscrição - o problema da presença e da ausência em um lugar. A informação estabelece uma interação material entre o centro e a periferia. Como qualquer um pode interagir com a informação da maneira 
que quiser a partir da sua ponta, sites de busca competem entre si, o que significa escolha para os usuários e inovações constantes. Não é necessário pedir permissão para estabelecer essa interação. Se você tem uma idéia, basta executá-la. E toda vez que você faz isso, o valor da Internet (rede) aumenta. Todo o valor da Internet cresce na sua periferia.

A circulação da informação estabelece uma zona de comunidade, isto é, a descoberta daquilo que há nos outros corpos e convém ao nosso.

\begin{abstract}
A "zona de comunidade", isto é, a descoberta daquilo que nos outros corpos convém ao nosso, é apenas o primeiro patamar de uma relação consistente. Naturalmente, por mais raro que tenha se tornado, este ainda é o patamar mais fácil de alcançarmos e aquele que, talvez, nos dará a força necessária para conhecer o que é mais difícil: aquilo que nos outros é diferente e corresponde a sua "zona de singularidade". Porque é preciso uma potência ainda maior para se conhecer, nos outros corpos, aquilo que não nos convém. Aquilo que nos afeta. Que nos é relevante. Este é o primeiro patamar de uma relação consistente. (TEIXEIRA, 2004).
\end{abstract}

Para Teixeira (2005), por mais raro que tenha se tornado, naturalmente este ainda é o patamar mais fácil de alcançarmos e aquele que, talvez, nos dará a força necessária para conhecer o que é mais difícil: aquilo que nos outros é diferente e corresponde a sua zona de singularidade. Porque é preciso uma potência ainda maior para se reconhecer, nos outros corpos, aquilo que não nos convém.

(...) é interessante ressaltar como há uma circularidade na lógica que une capital social e ação coletiva, especialmente útil de se compreender quando se pensa em intervenções para incrementar a IC [inteligência coletiva] dos grupos. É preciso capital social, isto é, um verdadeiro patrimônio de inter-relação humana, para se ampliar a potência das ações coletivas, mas, por outro lado, essas ações, como conseqüência, não cessam de enriquecer o patrimônio de inter-relação humana, não cessam de aumentar o capital social. O capital social, assim como outras modalidades de capital "imaterial", possui essa característica sui generis que faz com que seu uso não seja equivalente ao seu gasto e sim ao seu incremento. (TEIXEIRA, 2005).

fato de estar trilhando caminhos obscuros, seguindo pelas bifurcações da vida nos faz um experimentadores em diferentes sentidos. “(...) eu sentia que o 
mundo é um labirinto, do qual era impossível fugir, pois todos os caminhos, ainda que fingissem ir ao norte ou ao sul, iam realmente a Roma” (BORGES 1998, p. 564). Eis um paradoxo!

\subsection{O Infinito do Mundo Inteiro}

A sociedade sempre funcionou em rede. Os seres humanos vêm se organizando em redes colaborativas desde o começo dos tempos. Há muito que tal tipo de organização permite que sejamos capazes de transformar o mundo ao nosso redor, criando conhecimento e cultura de maneira coletiva. Não há sociedade, se não houver redes com conexões por um algum fator que combine anseios, interesses e desejos das pessoas.

Algumas idéias podem ajudar a montar um cenário filosófico que possibilite a compreensão de uma sociedade que está na Web. Não importa a maneira como nomeamos essa sociedade, pois, um único substantivo não compõe as múltiplas realidades desta experiência. Informação, colaboração, conexão, atenção ou conhecimento apenas complementam, em parte, a sociedade que vivemos.

Gabriel Tarde (2005, p. 113). nos apresenta uma visão da sociedade que denominou "sociologia da conversação". Nessa análise ele trata da diferenciação entre o público e a multidão por meio do movimento social. A multidão que se articula motivada por crenças e desejos através dos quais as pessoas são capazes de se imitarem e continuamente irem propagando suas idéias está permeada por públicos, formações conversacionais que emergem da influência dos meios de comunicação. Os meios são capazes de criar espaços para o compartilhamento de um comum que é vivenciado por públicos diversos. Por espaços de compartilhamento ou conversação o autor refere-se a todo o tipo de conversa cotidiana, cuja importância ou papel político não é, de maneira alguma, menor que seu papel linguístico. Segundo o autor, na origem da evolução das conversações 
está o movimento do poder e as capacidades de intervir na realidade. É da conversação do público que advém todo o movimento de inovação.

A idéia de mônadas ${ }^{25}$, baseada na filosofia de Leibniz, é outra metáfora instigante da diversidade em Gabriel Tarde (2007, p. 75). As mônadas são apresentadas como as partículas elementares, as substâncias simples de que os compostos são feitos. Elas são, portanto, diferenciadas (dotadas de qualidades que as singularizam umas em relação às outras) e diferenciantes (animadas por uma potência imanente de mudança contínua ou de diferenciação). Além disso, ou por isso mesmo, elas dizem respeito às nuances do infinitamente pequeno, do infinitesimal que constitui toda e qualquer diferença.

(...) se as mônadas são meios universais é porque não há agência sem outrem, não há existência fora da relação, não há relação sem diferença. Logo, se a sociedade é a possessão recíproca de todos por cada um é porque os processos de composição social não se realizam independentemente das micropolíticas da possessão que os constituem enquanto tais e que, portanto, Ihes são imanentes. (...) uma teoria social que coloque em suspensão (...) a antinomia entre o contínuo uniforme e o descontínuo pontual ou, mais precisamente, que pense as entidades finitas como casos particulares de processos infinitos (...) (TARDE, 2007, p. 37)

A hipótese das mônadas implica, portanto, a afirmação da diferença como fundamento da existência e, consequentemente, a renúncia ao dualismo cartesiano entre matéria e espírito e àqueles que lhe são correlatos - particularmente 0 dualismo natureza/sociedade tão caro a Durkheim e a todos os pensadores do período da modernidade que procuravam separar os pólos. A variação e o movimento da sociedade expressos em Gabriel Tarde têm por motivo a expressão de crenças e desejos pelos sujeitos. É pela expressão de subjetividade que se constrói o social, pelo choque e pela negociação de desejos.

\footnotetext{
${ }^{25}$ A palavra mônada foi criada na época da Renascença por Giordano Bruno (1548-1600) para referir-se aos elementos das coisas. Em Leibniz (1646-1716) as mônadas passaram a ter um lugar definido na história da filosofia significando uma "substância simples" ou elementos das coisas. (LEIBNIZ - 1714/1991 p.123-125).
} 
Tarde substitui a sociedade pelos sujeitos como quem troca o todo pelas partes. Ele propõe é substituir o grande pelo pequeno, as totalidades e as unidades pelas multidões. Ou, se ação é a essência da mônada é porque cada mônada já é multidão. Claudio Upiano (2008) diz sobre as mônadas de Leibniz como um espelho do universo que ao ser apontado para um objeto, o reflete e o reproduz. Mais do que isso: a mônada é finita, aquela que tem limites, contém dentro de si o infinito do mundo inteiro. Por sua vez, no que diz respeito ao universo microssocial, Gabriel Tarde esboçou em sua teoria social aspectos abrangentes capazes, na verdade, de lidar com o caos e a complexidade social. "Para Gabriel Tarde existir é diferir, é a possessão que nos leva de uma existência a outra, de uma diferença a outra", analisa Latour (2005). A concepção da sociedade como um movimento é o grande diferencial da teoria de Tarde.

Creio que vivemos numa sociedade do 'infinito do mundo inteiro'. Um espaço informacional que tende a crescer ao infinito. Teoricamente, não existe limite para o crescimento do fluxo de informação na Web. Mas essa informação cresce numa lógica de rede distribuída. Em 2007, David de Ugarte em El poder de las redes define uma rede distribuída por sua capacidade de continuar existindo mesmo que alguns nós sejam eliminados. $O$ autor analisa essa afirmação em termos políticos, energéticos, culturais, etc.: "O que temos de ter em mente é que a fórmula da rede social que liberta e se desenvolve de forma equilibrada é naturalmente distribuída".

De acordo com Leibniz, a lógica da mônada contempla o conceito de multiplicidade. As mônadas são entes porque têm qualidades. Isenta de qualidade uma mônada seria indistinguível de outra, pois não diferem em quantidade. Contudo, a diversidade de qualidade nas mônadas implica a multiplicidade de formas das coisas que compõem o mundo e faz a mônada ser uma estrutura que pode ser compreendida como uma multiplicidade contida na unidade. 


\subsection{O Monstro Revolucionário}

Deleuze e Guattari (1995) dizem: "A saber: aumentar a potência é precisamente compor relações tais que a coisa e eu, que compomos relações, só somos duas sub-individualidades de um novo indivíduo formidável". A concepção de multidão deve ser compreendida não como simples reunião de muitas individualidades. A multidão é um monstro revolucionário das singularidades não representáveis; parte da idéia de que qualquer corpo já é uma multidão e, por conseguinte, a expressão e a cooperação. A multidão é ela própria, uma individualidade, com sua própria potência, maior e diversa que a potência de cada corpo que entra em sua composição.

De qualquer forma, a informação está sendo produzida, distribuída, modificada ou remixada numa velocidade estonteante, cuja natureza semiológica se constitui em um fenômeno novo que altera os processos sociais de construção de significados. Recursos informacionais passam a essenciais, deixando de ser simples artifício de transmissão de conteúdos para se tornarem dispositivos produtores de sentidos, configuradores de uma nova ecologia cognitiva, simbólica e digital.

Habermas (1997) aposta na autonomia potencial dos agentes e falantes sociais perante esse quadro, a partir das pretensões veiculadas de validade criticáveis. Nesses termos, ele acredita que o movimento histórico, por meio de revoluções sociais, seria uma prova de relativização do poder vigente nesse âmbito. A citação que segue é bastante esclarecedora em relação a esse ponto:

Os mass media são capazes, simultaneamente, de hierarquizar, encolher e condensar os processos de comunicação, mas é somente em primeira instância que eles são suscetíveis de descarregar as interações de tomadas de posição afirmativas e negativas a pretensões de validade criticáveis; até mesmo as comunicações submetidas à abstração e condensadas não poderiam ser postas ao abrigo em toda a quietude contra as possíveis contradições de atores responsáveis. (HABERMAS, 1997, p. 430). 
Na Teoria da Ação Comunicativa, Habermas (1987) vê os meios de comunicação se desenvolverem em termos de formas generalizadas de comunicação, de modo que tais formas passem a ser regidas por meios de controle sistêmico, como o poder e o dinheiro. Percebe-se aqui uma proposição da comunicação comprometida em termos de sua dimensão simbólica, malgrado a autonomia dos indivíduos, com os meios de comunicação generalizados.

A hipótese do autor para esta questão é a de que o processo comunicativo se difunde tão rapidamente porque estabelece uma metáfora de totalidade, tendo em seu interior uma replicação das instituições sociais. Seria, então, através da eficácia de suas "analogias com o mundo" que a ação comunicativa se expandiria.

Esta proposição é interessante, porque traz à tona uma possibilidade de interpretação do fascínio exercido pela versão "mass-media" do ciberespaço, a Web. A cibercultura é um campo privilegiado para o estudo das relações entre mídia/usuário, ao estabelecer uma nova relação dos sujeitos com a tecnologia e com um meio cujo nível de interatividade é, até então, inédito.

Análises dessa natureza são enumeradas no inventário das problemáticas antropológicas relacionadas à cibercultura proposto por Arturo Escobar:

Como as pessoas relatam seus "techno-worlds" (máquinas,
corpos e natureza reinventados)? Se estão situadas
diversamente em espaços tecnológicos variáveis (de acordo
com etnia, sexo, classe social, localização geográfica,
"capacidade psicológica"), como as experiências de tais
pessoas sobre esses espaços se diferem? (ESCOBAR, 1994,
p. 217)

Segundo Manuel Castells (2006) existe uma transformação tecnológica e administrativa do trabalho e das relações produtivas dentro e em torno da "empresa emergente em rede" e que esse é o principal instrumento por meio do qual o "paradigma informacional e o processo de globalização afetam a sociedade em geral (...) em estágio avançado de transição à sociedade informacional e, portanto podem ser usados para a observação do surgimento dos novos modelos de mercado" e de trabalho. 
Assim, já é possível detectar nas sociedades mais avançadas a presença de novas figuras sociais, como os "digitais", como afirma Domenico DeMasi (2000) para quem o trabalho eventual só faz sentido se recheado de criatividade, se marcado pela ética e pela estética e se permitir que o ócio seja parte integrante dele, não com um sentido pejorativo, mas como momento de refluxo, de repouso, de lazer, que, aliado ao estudo não despreza jamais o desejo e o prazer.

Entre outras reflexões teóricas, essa pesquisa está baseada em aspectos conceituais que caracterizam a cultura contemporânea, entre os quais as noções de ecletismo, multiculturalismo, globalização, standartização e, principalmente, hibridismo, mestiçagem e "remix" ou aquilo que chamamos ética hacker. Desta forma, podemos compreender a proposição de inteligência coletiva de Pierre Lévy (2003). Espaços vazios na rede, intervalos entre processos de construção e desconstrução são espaços do saber que, segundo Lévy (2003, p. 202) o intelectual coletivo pode ocupar "desdobrando-se em um plano de imanência infinito, sem apropriação, sem inércia, é próprio dele deixar coexistir, acolher o ser em sua diversidade."

Rogério da Costa (2004) analisa a generosidade a partir do pensamento de David Hume de que nossa generosidade é limitada por natureza. O que nos é natural é uma generosidade limitada. O homem seria, então, muito menos egoísta do que parcial. A verdade é que o homem é sempre o homem de um clã, de uma comunidade. Sendo assim, a essência do interesse particular não é o egoísmo, mas a parcialidade. Com efeito, os egoísmos apenas se limitariam.

(...) a capacidade de interação dos indivíduos, seu potencial para interagir com os que estão à sua volta, com seus parentes, amigos, colegas de trabalho, mas também com os novos vizinhos, com alguém novo no bairro ou no trabalho etc. Quanto mais um indivíduo interage com outros, mais ele está apto a reconhecer comportamentos, intenções, valores, competências e conhecimentos que compõem seu meio. Inversamente, quanto menos alguém interage (ou interage apenas num meio restrito), menos tenderá a desenvolver plenamente essa habilidade fundamental que é a percepção do outro.(...) Ora, um dos aspectos essenciais para a consolidação de projetos coletivos, projetos que necessitam do engajamento de muitos em ações específicas é, sem dúvida, o sentimento de confiança mútua que precisa existir em maior ou menor escala entre as pessoas. A construção 
dessa confiança está diretamente relacionada com a capacidade que cada um teria de entrar em relação com os outros, de perceber o outro e incluí-lo em seu universo de referência. (COSTA, 2004).

Essa generosidade limitada está impregnada nos mutirões. No efeito puxadinho colaborativo. É só chegar para ajudar o ser humano a ser mais feliz. Uma mobilização que vai além da boa ação. É cotidiana e despretensiosa.

\subsection{A Multidão de Comuns}

Espinosa, citado por Claudio Ulpiano (2009) acerca de uma análise de pensamento e liberdade, inspira a idéia de que o homem só está em liberdade quando está no processo de inovação. Nesse momento, o homem não é subalterno; logo, é livre.

O homem livre é, pois, levado por uma tão grande força de alma a fugir oportunamente, como a combater; por outros termos, o homem livre escolhe com igual força de alma, ou seja, com a mesma presença de espírito, o combate ou a fuga. (ESPINOSA, 1973, p. 273).

A audácia do movimento, da ação, é condição de liberdade do homem. Essa inspiração influenciou a filosofia de Hardt e Negri (2005, p. 155) que, ao compor uma análise das relações de produção na pós-modernidade, resgatam a teoria marxista. Para esses autores, o aspecto central da produção imaterial é a sua relação íntima com a cooperação, a colaboração e a comunicação - em suma, sua fundamentação no comum. Ao descrever uma ruptura na unidade temporal de trabalho como medida básica de valor, apesar de o trabalho efetivamente continuar sendo a fonte essencial de valor na produção capitalista, os autores descrevem o surgimento do chamado trabalho imaterial, performático, baseado na comunicação e na produção do comum.

Ao referirem-se ao termo "comum", ressaltam o conteúdo filosófico da palavra deixando claro que comunicação, colaboração e cooperação não apenas se baseiam no comum, mas são capazes de produzir o comum. "Em outras palavras, o 
próprio trabalho, através das transformações da economia tende a criar redes de cooperação e comunicação e a funcionar dentro delas." (HARDT, NEGRI, 2005, p. 14).

Em rede, não apenas a produção de idéias, imagens e conhecimentos é conduzida em comum. O trabalho imaterial não só é produzido por aqueles que estão lidando diretamente com os meios de comunicação, mas todo o trabalho tende a se organizar em rede, desde o camponês que busca informações sobre determinada semente até os criadores de software:

De maneira geral, a hegemonia do trabalho imaterial tende a transformar a organização da produção, das relações lineares da linha de montagem às inúmeras e indeterminadas relações das redes disseminadas. A informação, a comunicação e a cooperação tornam-se as normas da produção, transformando-se a rede em sua forma dominante de organização. (HARDT, NEGRI, 2005, p. 155-156).

Um conceito fundamental que irá opor-se ao conceito de massa, preconizando a multiplicidade de formas singulares de vida (HARDT; NEGRI, 2005, p. 172) é o conceito de "multidão". A multidão abarca um montante de singularidades que operam em torno de um comum. É por meio da multidão que a democracia pode se estabelecer em meio à produção capitalista. No conceito de "multidão" há uma contradição implícita em oposição ao poder soberano.

Contra todos os avatares da transcendência do poder soberano (e nomeadamente o do 'povo soberano'), o conceito de multidão é o de uma imanência: um monstro revolucionário das singularidades não representáveis; parte da idéia de que qualquer corpo já é uma multidão, e, por conseguinte, a expressão e a cooperação. É igualmente um conceito de classe, sujeito de produção e objeto de exploração, esta definida como exploração da cooperação das singularidades, um dispositivo materialista da multidão poderá apenas partir de um tomada prioritária do corpo e a luta contra a sua exploração. (HARDT; NEGRI, 2005, p. 172).

Para os autores, a multidão tem como base o conceito marxista de classe. No entanto, esta definição entra em contradição com a própria estrutura de rede distribuída. O capitalismo, apesar de dominante, não consegue mais sustentar a 
lógica da acumulação e do trabalho. Seus principais alicerces, a economia, o paradigma da ética burocrática e a cultura de massas, estão em crise. Essa aponta a necessidade de uma nova ordem, uma reestruturação. Marx escreveu sua crítica em O Capital, num momento que a sociedade industrial estava aflorando, mas não se apresentava, ainda, como o paradigma dominante.

A tradição marxista clássica prescreve em relação ao capitalismo que os protagonistas da política sejam as classes sociais. Entretanto, o conceito de multidão descrito em Hardt e Negri (2005) estaria próximo ao que Deleuze e Guattari descrevem ao se oporem ao conceito de classe e de massa como formas rígidas de segmentação. A segmentação das classes sociais é molar, estriada e separa a sociedade em grupos opostos entre si de forma rígida. As massas, ao contrário, são agrupamentos moleculares, lisos que se mesclam entre si. Nesse sentido as "massas" seriam agrupamentos hábeis, transversais, não consolidados, instáveis, extremamente móveis e nômades.

Entretanto, mais do que perceber a razão da motivação das pessoas em projetos colaborativos é importante perceber que as relações sociais podem mobilizar mais que o dinheiro em si. A influência uns dos outros na participação colaborativa é determinante para o engajamento da multidão.

\subsection{O Comportamento Rizomático}

A multidão está em rede e a rede age por rizomas. O comportamento em rede é desterritorializando. Não há propriedade onde prevalece a sociedade da fartura. Esta é para nós a metáfora da rede e rizoma. O modelo é simples e virtual, ou seja, qualquer pessoa com um computador conectado à rede tem a possibilidade de participar do espaço informacional. Numa multidão hiperconectada o conhecimento livre tende a se expandir. A prática do conhecimento livre traz a reboque uma série de novos paradigmas que dialogam em tempo real com os enunciados que até agora deram sustentação filosófica à humanidade. Segundo Deleuze e Guattari (1995, p. 15): 
Um rizoma como haste subterrânea distingue-se absolutamente das raízes e radículas. Os bulbos, os tubérculos, são rizomas. Plantas com raiz ou radícula podem ser rizomórficas num outro sentido inteiramente diferente: é uma questão de saber se a botânica, em sua especificidade, não seria inteiramente rizomórfica. Até animais o são, sob sua forma matilha; ratos são rizomas. As tocas o são, com todas suas funções de hábitat, de provisão, de deslocamento, de evasão e de ruptura. O rizoma nele mesmo tem formas muito diversas, desde sua extensão superficial ramificada em todos os sentidos até suas concreções em bulbos e tubérculos. Há rizoma quando os ratos deslizam uns sobre os outros. Há o melhor e o pior no rizoma: a batata e a grama, a erva daninha. Animal e planta, a grama é o capim-pé-de-galinha. Sentimos que não convenceremos ninguém se não enumerarmos certas características aproximativas do rizoma. (DELEUZE; GUATTARI, 1995, p. 15).

Deleuze e Guattari (1995) contrapõem esta noção de rizoma à noção de árvore. A metáfora das ramificações arborescentes nos ajuda a entender uma espécie de programa mental. Árvores são plantadas em nossa mente: árvore da vida, árvore do saber, etc. E o poder, na sociedade, é sempre arborescente - a metáfora visualiza, comunica melhor o sentido dessa estrutura que representa a hierarquia. Mas na organização do saber, quase todas as disciplinas passam por esquemas de arborescência: a biologia, a informática, a linguística (os autômatos ou sistemas centrais). De acordo com Parente (2004) não se trata de uma simples metáfora (no sentido linguístico), mas sim do que se pode entender a partir dessa metáfora: que existe todo um aparato que se planta no pensamento, um programa de funcionamento para obrigá-lo a ir pelo 'bom' caminho, das idéias 'justas'. O modelo de árvore clareia a maneira de como se articulam, na comunicação social, os esquemas de poder.

Entretanto: "Um rizoma não começa nem conclui, ele se encontra sempre no meio, entre as coisas (...) A árvore é filiação, mas o rizoma é aliança (...). A árvore impõe o verbo 'ser', mas o rizoma tem como tecido a conjunção "e... e... e..." (DELEUZE; GUATTARI, 1995, p. 37). Há nesta conjunção força suficiente para sacudir e desenraizar o verbo ser. Entre as coisas, ela não designa uma correlação localizável que vai de uma para outra e reciprocamente, mas uma direção 
perpendicular, um movimento transversal que as carrega uma e outra, riacho sem início nem fim, que rói suas duas margens e adquire velocidade no meio.

Essas características das redes podem ser aplicadas aos organismos, às tecnologias, aos dispositivos, mas também à subjetividade. Somos uma rede de redes (multiplicidade), cada rede remetendo a outras redes de natureza diversa (heterogênese), em um processo autoreferente (autopoiésis). Esse rizoma se regenera continuamente por suas interações e transformações.

O trabalho de James Surowiecki (2005) em The wisdom of crowds faz uma colocação sobre diversidade e independência.

\begin{abstract}
Diversidade e independência são importantes porque as melhores decisões coletivas são produto de desacordos e contestações, ausência de consenso ou compromisso. Um grupo inteligente, especialmente quando se vê confrontado com problemas de cognição, não pede a seus membros que mudem suas posições, mas deixa que o grupo tome uma decisão de acordo com o que cada um sinta o que é melhor para ele. Em vez disso, ele calcula como usar outros mecanismos - como os de preços de mercado ou sistemas de votação inteligente - para agregar e produzir julgamentos coletivos que não representem o que uma pessoa do grupo pensa, mas antes, em certo sentido, o que todos pensam. Paradoxalmente, o melhor modo de um grupo ser inteligente é cada membro dele pensar e agir com o máximo de independência possível (SUROWIECKI, 2005, p. XIX-XX).
\end{abstract}

A multidão se faz na inteligência das relações e multiplicidades entre as partes.

\title{
4.8 Produção Biopolítica
}

Entendemos que desde a revolução de Gutenberg a humanidade não apresentou algo tão original como a Internet para o rompimento do paradigma cultural efetivado pelo modernismo. A conversa de muitos para muitos tem um alcance espetacular na relação de poder. Em Foucault (1993) tem início uma primeira análise dessa relação de poder: 
Parece-me que se deve compreender o poder, primeiro, como a multiplicidade de correlações de forças imanentes ao domínio onde se exercem e constitutivas de sua organização; o jogo que, através de lutas e afrontamentos incessantes as transforma, reforça, inverte; os apoios que tais correlações de força encontram umas nas outras, formando cadeias ou sistemas ou ao contrário, as defasagens e contradições que as isolam entre si; enfim, as estratégias em que se originam e cujo esboço geral ou cristalização institucional toma corpo nos aparelhos estatais, na formulação da lei, nas hegemonias sociais. (FOUCAULT, 1993, p. 88-89).

O poder, para Foucault (2005), provém de todas as partes, em cada relação entre um ponto e outro. Essas relações são dinâmicas, móveis, e mantêm ou destroem os esquemas de dominação. A correlação de forças imanentes é expressa na rede como Zonas de Colaboração cujo conceito é o espaço informacional onde as pessoas comuns estão engajadas no desenvolvimento de comunidades, de relações, nas conversações.

A noção de biopolítica foi forjada por Foucault para designar uma das modalidades de exercício do poder sobre a população enquanto massa global. Hardt e Negri (2004) e Maurizio Lazzarato (2004, p. 204) propõem uma pequena inversão conceitual. Para eles a biopolítica deixa de ser a perspectiva do poder sobre o corpo da população e suas condições de reprodução, sua vida. A própria noção de vida deixa de ser definida apenas em termos dos processos biológicos que afetam a população.

É preciso insistir no fato que a atividade implícita ao trabalho imaterial permanece, ela mesma, material - ela engaja nosso corpo e nosso cérebro, como em qualquer trabalho. O que é imaterial é seu produto. $E$, desse ponto de vista, nós admitimos que a expressão 'trabalho imaterial' é bastante ambígua. Talvez, por isso, seja preferível falar de 'trabalho biopolítico', isto é, um trabalho que cria não somente bens materiais, mas também relações e, em última instância, a própria vida. 


\subsection{O Mundo de Pontas}

Em World of Ends, David Weinberger e Doc Searls (2003) colocam que ao olharmos para um poste, vemos redes como fios. Mas a Internet é diferente. Não é fiação. Não é um sistema. E não é uma fonte de programação. A Internet é um modo que permite a todas as coisas que se chamam redes coexistir e trabalhar em conjunto. É, literalmente, uma Inter-net (inter-rede). O que faz a "net" ser "inter" é o fato de ela ser apenas um protocolo, mais precisamente, - o protocolo Internet (IP "Internet Protocol").

Um protocolo é um acordo acerca de como fazer as coisas funcionarem em conjunto. Este protocolo não especifica o que as pessoas podem fazer com a rede, o que podem construir na sua periferia, o que podem dizer ou quem pode dizer. $O$ protocolo simplesmente diz: se você quer trocar bits com outros, é assim que se faz. Se você quer conectar um computador - ou um celular ou uma geladeira - à Internet, você tem que aceitar o acordo que é a Internet. De acordo com Galloway (2004) esse protocolo não apenas instala o controle, mas é fundamentalmente a tecnologia de inclusão; a abertura é a chave para essa inclusão. A cultura hacker percebe a imaturidade desses protocolos e propõe uma nova ética que vem, não para romper os paradigmas que ainda não existem, mas sim forjar um novo modelo. Esses argumentos e idéias me levam a pensar na Internet como um espaço para agenciamentos, capazes de tornar possíveis saltos muito perceptíveis tanto em relação às transformações no comportamento ético quanto na ação direta da microfísica do poder.

Nessa espuma informacional emergem novas formas de interação. Listas de discussão, blogs, flogs, Orkuts, mensagens instantâneas, ou qualquer outra ferramenta que conecte grupos. Esses grupos formam focos de movimentos sociais. Quanto mais engajado for o projeto, mais intensa será a ação coletiva. Mas é especialmente esse fuzuê informacional que torna possível a catalisação do agenciamento coletivo.

Numa multidão hiperconectada o conhecimento livre tende a se expandir. No entanto, a prática do conhecimento livre traz a reboque uma série de novos 
paradigmas que dialogam em tempo real com os enunciados que até agora deram sustentabilidade filosófica à humanidade. Estamos presenciando mudanças drásticas nos debates sobre propriedade intelectual, liberdade de expressão, nas políticas de comunicação. Estamos apenas no início desta revolução não televisionada.

No artigo Post-Scriptum sobre as cidades do controle, Deleuze (1990) aponta para a passagem da sociedade disciplinar para a sociedade de controle. Segundo ele, não precisamos mais da forma de enclausuramento das instituições disciplinares, pois o controle pode ser exercido ao ar livre, sobre os fluxos. Isso significa que não precisamos mais de muros para controlar. O controle se faz pela interação e em rede.

Perguntamos então: será que a sociedade não estaria engendrando uma espécie de prisão ainda mais aperfeiçoada do que todas as outras, por intermédio da conexão ao ciberespaço, pela virtualização das relações humanas, pela ubiquidade, ou por qualquer outra tecnologia que nos permite ir a todos os lugares sem sair do lugar? Michel Serres (apud. PARENTE, 2004) chama esta condição de pantopia, em $A$ lenda dos anjos, que significa todos os lugares em um só lugar e cada lugar em todos os lugares. Enquanto para Paul Virilio (2000), esse movimento seria negativo, para Serres é positivo.

Se o espaço do enclausuramento tende a migrar para as relações com o ciberespaço, para Virílio (2000) significa o fim do espaço. Pois, "chegaremos ao tempo em que não haverá mais campo de tênis, mas um campo virtual; não haverá passeio de bicicleta, mas exercícios em um home-trainer (...) o espaço não se estenderá mais".

Essa idéia que ciberespaço é o fim do espaço, ou que a ubiquidade absoluta anule anula todo o espaço é uma utopia tecnológica. Logicamente, isto não nos torna mais humanos, mas numa simples navegação pelos sites e blogs podemos perceber que essa ruptura nos leva a um novo bom senso. Muito mais humanista, que potencializa a colaboração entre as pessoas. Pois, a conexão e a preocupação nos fazem humanos. 
A relação de mistura e conexão que a rede forma, cria um espaço diferente. $A$ reconfiguração do espaço que iguala o físico e o virtual: todos os lugares num só lugar e cada lugar em todos os lugares. Na Internet, a informação é o mundo, se a informação é mundo e se este mundo está em rede, então temos tanto a possibilidade de ter todos os lugares quanto a de estar em todos os lugares. Pantopia remete tanto à utopia quanto ao espaço heterotópico, que em Foucault aparece como os diversos agrupamentos dos diferentes tempos e espaços.

O ciberespaço - ou o espaço informacional - não significa anulação do espaço, mas apenas a realização tecnológica do espaço topológico. Ou seja, no ciberespaço vivemos relações de vizinhança, espaço de conexões, herotópico e pantópico. O espaço, segundo Foucault, passa a ser definido pelas relações de vizinhança entre pontos e elementos, formando séries, tramas, grafos, diagramas, redes. E assim, remixando Espinosa: liberdade é uma conquista, não um direito.

O crescimento desta mídia binária é muito rápido. Estamos adotando as tecnologias na Internet numa velocidade absurda. Existe uma diferença em relação aos outros meios. As pessoas estão conversando na rede de uma forma muito peculiar. Usamos e-mails, blogs, listas, twitter, chats, e redes sociais para reverberar as palavras. A sedução espiritual da Web é a promessa do retorno da voz da multidão invisível. Queremos resgatar a capacidade de comunicação.

No final dos anos 90, entramos nessa onda sem saber exatamente para que servia a Internet. As pessoas logo entenderam que é barato falar na rede. Além disso, a distribuição livre de informação deixava as pessoas mais inteligentes, mais capacitadas para participar do dinamismo da Web. Afinal, sempre quisemos falar para o mundo. Recuperar a voz perdida e romper com a hierarquia das organizações, mostrando o nosso valor.

O Manifesto Cluetrain expôs os mercados são conversações. E esta conversação faz as pessoas se aproximarem, para uma auto-organização da sociedade civil. Esta é a proposta do movimento dos códigos livres. Uma organização colaborativa, anárquica e disforme. Poderosa pela essência que une as pessoas num projeto comum. A rede faz este movimento aflorar, apavorando o 
grande monopólio, as grandes corporações, os acordos dos mestres capitalistas. No entanto, a revolução digital ganha corpo. É difícil combater a organização de pessoas comuns; ela é emergente. Funciona nos links.

Estamos todos, direta ou indiretamente, linkados. As pessoas se linkam umas às outras por laços ou nós de vários tipos. Estes, por sua vez, se constituem enquanto matéria interessante para analisar as relações entre as pessoas, culturas, instituições e sociedades.

Link é poder. Refletindo sobre este poder ao longo da história, percebemos que a sociedade não estaria constituída da maneira como a conhecemos não fosse pela articulação das pessoas, por interesses, laços familiares ou quaisquer outras manifestações humanas que levem uma pessoa a se relacionar.

Chris Locke diz que a rede é a anfetamina das conversações. Esse parlatório está modificando toda a estrutura de poder. Pessoas comuns falando e desenvolvendo projetos pessoais repercutem novas idéias desbalanceando o entre dos mercados $\mathrm{e}$ das empresas. A Internet trouxe a idéia de revolução e também críticas inequívocas acerca de como a sociedade moderna está estruturada. Romper paradigmas significa destruir os preconceitos nos quais estamos inseridos.

Desde o ponto de vista da conversação em rede que estaremos tratando a pesquisa sobre as Zonas de Colaboração e, mais especificamente no moviemento do MetaReciclagem. $O$ que interessa nesse momento é compreender como um grupo emergente, que se forma como uma multidão hiperconectada, tem conseguido impactar desde projetos independentes de apropriação tecnológica como a política pública de inclusão digital no Brasil.

Desta forma, estaremos a partir desta proposta de qualificação, retomando à análise do MetaReciclagem, desenvolvendo o objeto de estudo sob o viés das intervenções comunicativas do movimento como mídia tática - uma subversão tática da mídia. Subversão no sentido de inversão, do desvio do uso tático. Para Garcia e Lovink (1997), mídia tática é o uso de forma mais crítica dos 'aparelhos' de 
mediação para o "questionamento das informações circulantes de um modo mais bem mais participativo e opositor que as mídias convencionais."

A mídia tática não visa repetir o conceito de comunicação de massa. Subverte pela negação e pela reciclagem da linguagem imposta. É a revolução dos mercados que sentem que a comunicação de massa não atende aos anseios da sociedade. $E$ buscam a descentralização da informação. E, segundo Garcia e Lovinck (1997) "atingem assim um público amplo e de diversas classes sociais com múltiplas e criativas (não utópicas, ilusórias e imparcial) formas de visões sobre fatos relativos à sociedade, política, ecologia, educação, cultura, conspirações." Algumas vezes a proposta do movimento, ou seja, a apropriação da tecnologia se confundirá com a ação comunicativa.

Buscar pelos resultados das Zonas de Colaboração, espaços informacionais de tazes flutuantes, é o foco do próximo capítulo da pesquisa. Observar as zonas temporárias autônomas segundo Bey (2001) e suas ações livres, esse é o objeto dessa pesquisa, mais propriamente tornar esses movimentos em rede perceptíveis através da investigação no MetaReciclagem uma conversação em rede que teve início nos idos de 2002 e permanece até hoje como uma Taz na qual a potência da apropriação e da colaboração do conhecimento por meio das ferramentas de conversação parece ser algo possível de se observar. 


\section{Objeto, Hipóteses e Método de Pesquisa}

O esboço dos métodos investigativos adequados para a realização desse estudo não prescinde da definição do objeto a ser pesquisado e de seu contexto no campo de estudo da comunicação.

Inserida na Linha de Pesquisa Comunicação e Ambiências em Redes Digitais, na Área de Concentração Teoria e Pesquisa em Comunicação do PPGCom (Programa de Pós-Graduação em Ciências da Comunicação) a pesquisa propõe o foco de estudo no campo de conhecimentos definido como Internet Studies. De acordo com Silver (2004, p. 57) os Internet Studies reúnem em uma série de investigações sociológicas e comunicativas que abrangem a cultura virtual e que culminam em uma ontologia acerca de aspectos culturais, sociais e políticos da Internet.

O tema de pesquisa, inserido no contexto da inclusão digital no Brasil, é a formação de Zonas de Colaboração no movimento ou rede de pessoas denominado MetaReciclagem ${ }^{26}$ : uma rede que teve início em 2002 por meio de uma lista de discussão na Internet que visava propiciar debates a respeito da Internet no Brasil e apresentar uma metodologia de apropriação social da tecnologia que poderia ser utilizada/replicada em diferentes contextos sociais. A MetaReciclagem envolveu a participação de ativistas, filósofos, comunicadores, programadores, mas, principalmente, de pessoas comuns interessadas em aprender e discutir sobre a inclusão digital no Brasil. Os fundadores do movimento já possuíam a experiência de compartilhar conhecimento adquirida no Projeto Metá:fora ${ }^{27}$.

A MetaReciclagem propõe o desenvolvimento de projetos independentes voltados à educação, tecnologia, arte e design, em vista da necessidade de uma

26

MetaReciclagem: disponível em: http://rede.metareciclagem.org/ Acesso em 31 maio 2010.

27. Metá:fora: projeto com início em 2000 a partir de uma simples lista de discussão e muita vontade de compartilhar o conhecimento. Um grupo de pessoas, numa conversa descompromissada na Internet que pretendia a criação de um canal de pesquisa sobre comunicação, Internet, filosofia e cibercultura. Um projeto aberto, baseado nos conceitos do software livre e liberação dos códigos. Disponível em: http://www.marketinghacker.com.br/index.php?itemid=2367 Acesso em: 31 maio 2009. 
estrutura tecnológica livre e autônoma a partir da desmistificação e apropriação tecnológica.

\begin{abstract}
A idéia do MetaReciclagem se baseia, então nos princípios: de reapropriação tecnológica, desmistificando a máquinacomputador como um quebra-cabeças simples, que deve ser aberto e exposto, promovendo o intercâmbio de idéias e cooperação; do software livre, por entender o conhecimento como bem coletivo, apropriável; e a descentralização integrada, por listas de discussão, perfazendo a troca de conhecimento e oportunidades entre os membros dos diversos esporos do projeto. Além disso, a possibilidade de replicação do modelo, a valorização da autonomia e do aprendizado, fazem do MetaReciclagem, sobretudo, um facilitador de troca de ações, de disseminação através do compartilhamento social das ações. (ROSAS, 2007).
\end{abstract}

Uma das formas mais atuantes do MetaReciclagem ao longo dos anos ocorreu por meio da frequente realização de oficinas e instalação de laboratórios em comunidades com poucos recursos de acesso às TICs. Além da proposta de lidar com as máquinas em si (montagem/desmontagem e reaproveitamento de computadores), a Rede MetaReciclagem apresentou um veio artístico importante, configurando-se no canal de comunicação mais eficaz da ação de apropriação nas comunidades em que esteve em contato. Tal proposta ou inovação surgiu com o trabalho do artista Glauco Paiva que ingressou no Metareciclagem em 2003. A partir daquele momento, não apenas era possível montar o próprio computador adquirindo e compartilhando o conhecimento, como também passou a ser possível redecorá-lo, pintar as CPUs, monitores e demais peças. Assim, a ação de apropriação passou do ato de transformar peças de cores cinza, frias e com algum sentido, não mais em uma simples ferramenta ou computador que poderia ser reutilizado, mas em algo novo, diferente, em novas ferramentas, únicas, criadas pelos usuários e participantes das oficinas em uma produção subjetiva. 

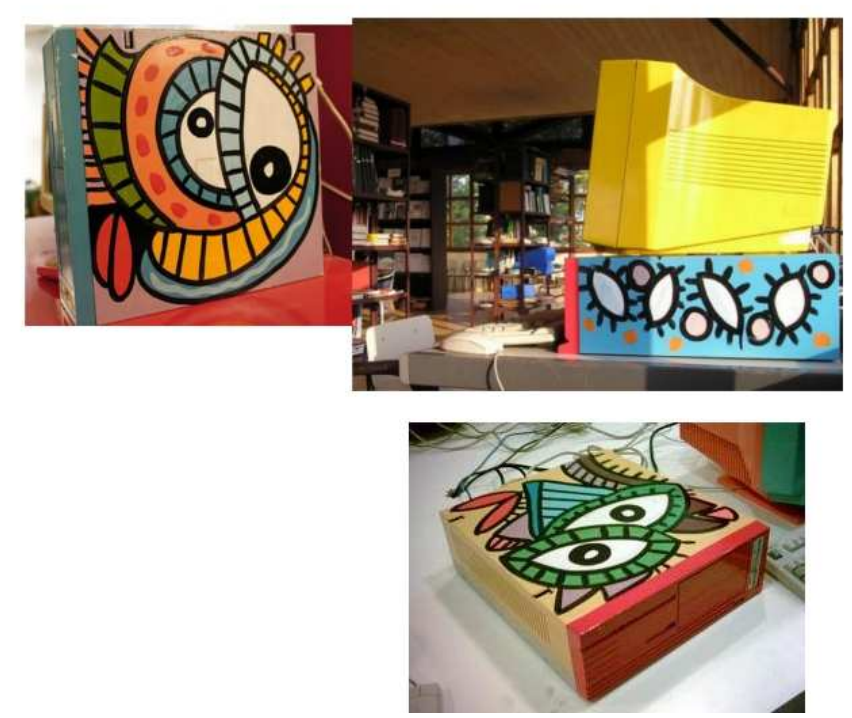

Imagens de comutadores reciclados na proposta de apropriação do MetaReciclagem através da arte, pintura de gabinetes e computadores. Proposta implementada pelo artista Glauco Paiva que se disseminou como prática replicativa no movimento em várias regiões do Brasil.

Figura 1. Computadores Reciclados e Proposta de Apropriação Artística

Ao estimular a pintura das carcaças das CPUs e monitores por parte dos participantes, com suas próprias temáticas pessoais ou comunitárias, bem como promovendo 0 conhecimento do mecanismo e estrutura interna das máquinas, sua reciclagem e manutenção, o MetaReciclagem não apenas compartilha socialmente um conhecimento e propicia uma intimidade antes pouco aventada em relação a computadores, como "redesenha" a própria noção de "inclusão digital", cuja abordagem por parte de certas estratégias de governos locais de desenvolvimento social no Brasil poucas vezes atentou para detalhes mais subjetivos daqueles que acessariam estas máquinas ou mesmo que o conhecimento de sua estrutura interna, funcionamento ou reciclagem poderia gerar novas possibilidades profissionais ou similares. (ROSAS, 2007).

O conceito de tecnologia social segundo as autoras Jardim; Otero (2004) engloba um conjunto de técnicas, metodologias transformadoras, desenvolvidas e/ou aplicadas na interação com a população com o objetivo de apropriação, que representam soluções para inclusão social e melhoria das condições de vida. É importante pensar que tecnologia social deve ser vista como processo mais que uma finalidade. Um movimento que se constitui como parte da consolidação da rede/sociedade conforme menciona Latour (2005, p. 19) numa abordagem sociotécnica da multidão. Um movimento em que os atores se influenciam constantemente e tomam decisões capazes de afetar uns aos outros 
especialmente por meio de intervenções comunicativas. O ator está envolvido e participa do tecido social permeado por seres animados e inanimados (computadores, animais, contingências situacionais, pessoas, grupos) onde acontece o uso, a apropriação, a revitalização ou o repotenciamento de conexões. O processo de apropriação da tecnologia, ao adquirir dimensões e implicações políticas de desenvolvimento para a comunidade e para a nação, suprindo algumas necessidades e expectativas (desejos em ritmo de expansão) caracteriza a tecnologia social.

Tal conceito de apropriação da tecnologia social é proveniente principalmente do MetaReciclagem permeando a idéia de reapropriação. No MetaReciclagem o conceito abrange diversas formas de ação: da captação de computadores usados e montagem de laboratórios reciclados utilizando software livre até a criação de ambientes de circulação da informação através da Internet (blogs, listas), passando por todo o tipo de experimentação, apoio estratégico e operacional a projetos socialmente engajados.

Segundo Dimantas (2010) e Fonseca (2009) o MetaReciclagem, com o passar do tempo, não cabia mais na denominação genérica e oportunista da inclusão digital. Nesse tempo, seus integrantes passaram a procurar níveis mais elaborados de ação crítica e compreensão da apropriação de tecnologia como fenômeno social. Conceitos como colaboração, produção coletiva de conhecimento, ressignificação da tecnologia e apropriação crítica passaram a servir de base para outros níveis de experimentação e criação.

De um grupo inicialmente reduzido, o MetaReciclagem transformou-se em metodologia livre e aberta, passível de replicação em qualquer contexto e, com o tempo, sendo adotada em diversos projetos de tecnologia social. Atualmente, o MetaReciclagem pauta e influencia políticas públicas de universalização do acesso à tecnologia e de democratização da produção de conhecimento, além de participar de intercâmbios com outros projetos em todo o mundo.

Segundo os autores Jardim; Otero (2004), Dangino; Novaes (2003) e Dangino; Brandão; Novaes (2004) são características e consequências 
respectivamente do movimento de apropriação da tecnologia social: (1) desenvolvimento em interação; (2) aplicação na interação; (3) apropriação pela população.

Dentre as conseqüências da apropriação tecnológica estão:

- apropriação do conhecimento, inovação;

- produção de conhecimento para transformação social;

- cidadania;

- alteração do modo de intervir diante das questões sociais devido ao "empoderamento" da população por meio da troca de conhecimento;

- transformação no modo de as pessoas se relacionarem com algum problema ou questão social.

Diante desse esboço é possível observar que qualquer projeto de inclusão digital ou social que perpasse pelo conceito de apropriação da tecnologia social deve atentar para o fato de que as técnicas e metodologias devem ser transformadoras e participativas.

Esse estudo tem um foco na atuação do MetaReciclagem como uma máquina comunicativa num espaço onde centenas de pessoas através de ferramentas de comunicação on-line convivem num ambiente de Zonas de Colaboração, no qual, pode-se dizer, o caos e a conversação imperam. Observando os rumos tomados pelo movimento a partir das conversas na Internet, desde o seu plano de ação inicial, torna-se possível considerar a proposta de intervenção nos moldes de uma pesquisa-ação de acordo com Le Boterf (1999):

Uma das características da PA [Pesquisa-Ação] consiste no fato de que seu dispositivo, concebido de acordo com a sua dimensão social, estabelece uma rede de comunicação ao nível da captação de informação e de divulgação. A PA faz parte de um projeto de ação social ou da resolução de problemas coletivos. (LE BOTERF, 1999, p. 84). 
Outra característica da Pesquisa-Ação de acordo com Thiollent (2007) é o forte vínculo ou envolvimento do pesquisador com a proposta de intervenção acionada. Em relação a tal postura é favorável considerar que o distanciamento é possível e necessário (objeto de vigilância epistemológica) pelo pesquisadorparticipante que não se torna, de maneira alguma, imune às tendências e idéias expressas no movimento de investigação proposto a partir do método. Entretanto por meio da capacidade de organizar um conhecimento teórico advindo da experiência de intervenção e "encaminhar explicações ou interpretações dos fatos observados" (THIOLLENT, 2007, p. 105) é que a Pesquisa-Ação engloba uma reflexão coletiva sobre a intervenção proposta, por meio de depoimentos de seus participantes e retorne com uma avaliação da atuação na realidade. Segundo Lopes (2005):

(...) os 'fatos' não devem se impor absolutamente como verdade - como se impõem nas práticas sociais correntes fatos em seu lugar teórico, como 'dados', estabelecendo-se uma passagem dos fatos aos dados e vice-versa. (LOPES, 2005, p. 128).

O primeiro momento de ação da pesquisa pressupõe a organização do grupo por meio de um cronograma de atividades definidas de modo que nos primeiros encontros entre os participantes aconteçam debates e discussões a respeito dos temas de interesse do grupo. Alguns temas são confrontados e, quando expostos, cumprem o papel de norteadores do movimento e das futuras intervenções. No MetaReciclagem, o primeiro movimento da pesquisa-ação já aconteceu em 2002, ano em que os membros da rede deram início às discussões presenciais e na Internet sobre processos de inclusão digital no Brasil. A partir dessa prática de experimentação foi possível levantar propostas de ação e desenvolver projetos com base nas reflexões e soluções apresentadas.

$O$ atual problema de pesquisa se apresenta como um segundo momento de intervenção e, propondo uma metareflexão sobre o processo de comunicação que ocorreu no MetaReciclagem ao longo dos anos, procura observar de que forma 0 processo de comunicação na Rede MetaReciclagem constituiu-se em Zonas de 
Colaboração entre os participantes e como resultaram em ações de intervenção em situações e contextos sociais no Brasil? A metodologia pesquisa-ação cuida de uma intervenção do pesquisador no âmbito do agenciamento coletivo e propõe a análise de intervenções comunicativas na realidade.

A pesquisa parte das seguintes hipóteses:

- $1^{a}$ hipótese: a criação na rede de Zonas de Colaboração por meio de ações comunicativas se configura como um rizoma no processo de apropriação da tecnologia social.

- $2^{\mathrm{a}}$ hipótese: as características da rede (multiplicidade, compartilhamento de informações, produção de subjetividade) são capazes de gerar transformações e intervenções em situações sociais por meio de agenciamentos coletivos.

- $3^{\text {a }}$ hipótese: a evolução das conversações oriundas da Web resulta em potência para intervir em situações sociais.

\subsection{Objetivos Gerais}

- Contribuir para ampliação e discussão do conceito de Zonas de Colaboração como objeto de estudo científico no campo da comunicação, através da emergência de vozes mediadas pelas tecnologias de informação e comunicação.

- Contribuir para uma aproximação da cultura acadêmica com processos colaborativos de compartilhamento de conhecimento e realização de projetos em rede, trazendo para a academia conceitos e métodos da cibercultura e linkania, visando enriquecer repertórios pela via do conhecimento acadêmico. 


\subsection{Objetivos Específicos}

- Verificar, no contexto brasileiro, a atuação das Zonas de Colaboração, no processo de comunicação descentralizada levando ao conhecimento acadêmico já institucionalizado essa abordagem comunicativa-tática.

- Propor uma reflexão aos participantes do movimento e aos acadêmicos sobre o MetaReciclagem como um projeto de intervenção na cultura digital brasileira e de apropriação da tecnologia social: o significado das ações do grupo e os resultados no contexto sócio-cultural brasileiro.

\section{3 Técnica de Coleta de Dados}

O presente trabalho pode ser caracterizado como pesquisa de natureza básica uma vez que apresenta uma investigação em área recente da comunicação. A abordagens quantitativa e qualitativa com foco exploratório descritivo nos moldes de uma avaliação e reflexão sobre o processo comunicativo do MetaReciclagem. Por ser uma pesquisa exploratória, cujo objeto não fora ainda pesquisado na área da comunicação, a abordagem qualitativa prima por revelar dados mais precisos na investigação.

\subsubsection{Técnica de Coleta de Dados Quantitativos}

Os dados quantitativos da pesquisa correspondem à coleta de posts de conversações, trocas, e threads (fluxos de discusão) realizadas pelos integrantes da Rede MetaReciclagem. O que interessa nessa coleta é o número de posts trocados ao longo dos anos pelos integrantes do MetaReciclagem e não o conteúdo neles encontrado. Os dados coletados encontram-se disponíveis no ambiente virtual lista de discussão do MetaReciclagem http://www.metareciclagem.org. 


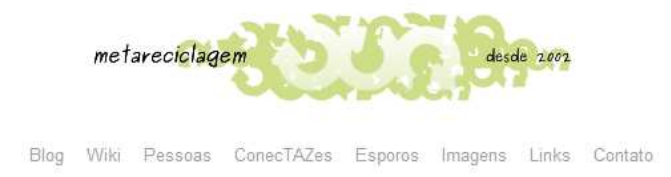

\begin{tabular}{|c|c|c|c|}
\hline \multirow[t]{2}{*}{ Login do usuário } & \multirow{2}{*}{\multicolumn{2}{|c|}{ Apropriação tecnológica para a transformação social }} & Blog \\
\hline & & & $\begin{array}{l}\text { - Tudo en Ação: The Internet of } \\
\text { Things }\end{array}$ \\
\hline Nome de usuário: * & & & - Cor e sabor na cparty \\
\hline \multirow[t]{2}{*}{ Senha: * } & metareciclagem & & - Ver Gambiarras \\
\hline & $\begin{array}{l}\text { MetaReciclagem é uma rede auto-organizada que propöe a c } \\
\text { transformação social. }\end{array}$ & desconstrução da tecnologia para a & - Jaiminho também faz projetos \\
\hline \multirow{3}{*}{$\begin{array}{l}\text { Login } \\
\text { - Criar nova conta } \\
\text { - Solicitar uma nova senha }\end{array}$} & Se você quer ser desconstruidx e re-construidx, ter & & Comentários recentes \\
\hline & suas idéias modificadas, reificadas, pisoteadas e amadas, se seu & $\begin{array}{l}\text { PRODUTOS, } \\
\text { MÉTODOS, }\end{array}$ & - blz, uma hora chega \\
\hline & $\begin{array}{l}\text { ego è grande o suficiente para ter amor ao que faz mas } \\
\text { consegue reconhecer o que os outros fazem sem }\end{array}$ & $\begin{array}{l}\text { COMPARTILHE } \\
\text { O CONHECIMENTO }\end{array}$ & ha 2 dias 13 horas \\
\hline \multirow[t]{3}{*}{ Rede MetaReciclagem } & inveja, se não está aqui buscando promoção social, mérito ou & PERMITA A REPULCACÁA LUVRE. & há 2 dias 14 horas \\
\hline & mundo perfeito, seja bem-vindx à rede Metareciclagem. & & há 2 dias 14 horas \\
\hline & Uma rede onde malucxs conversam, jogam bola, mandam emails, & & Mudanças recentes no wiki \\
\hline $\begin{array}{l}\cup \text { Blogs } \\
\cup \text { Conversas } \\
\cup \text { Links }\end{array}$ & $\begin{array}{l}\text { discutem e fazem as pazes, filosofam sobre vida e morte, } \\
\text { colaboração, apropriação de tecnologia, como as coisas } \\
\text { são por dentro, de onde viemos e para onde vamos. }\end{array}$ & $\begin{array}{l}\text { (2). APROPRIE-SE } \\
\text { OCUPE, REPLIQUE, } \\
\text { REINVENTE. } \\
\text { CONTINUE RECILLANDO SEM PARAR. }\end{array}$ & $\begin{array}{l}\text { Alteraçōes recentes no wiki deste site. } \\
\text { Essa página também tem uma versão } \\
\text { RSS. }\end{array}$ \\
\hline
\end{tabular}

Figura 2. Página inicial da Lista de Discussão MetaReciclagem

Disponível em: http://rede.metareciclagem.org/ Acesso em 15 fev. 2010

\section{Apropriação tecnológica para a transformação social}

\section{metareciclagem}

MetaReciclagem é uma rede auto-organizada que propóe a desconstrução da tecnologia para a transformação social.

Se você quer ser desconstruidx e re-construidx, ter suas idéias modificadas, reificadas, pisoteadas e amadas, se seu ego é grande o suficiente para ter amor ao que faz mas consegue reconhecer o que os outros fazem sem inveja, se não está aqui buscando promoção social, mérito ou grana, e se, acima de tudo, acredita em fadas, duendes e um mundo perfeito, seja bem-vindx à rede Metareciclagem.

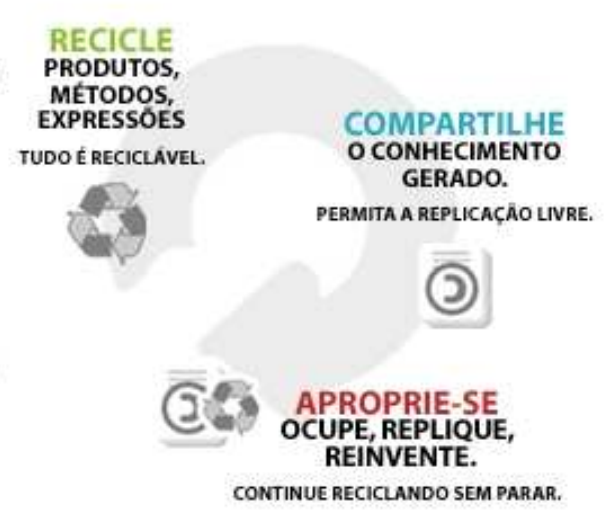

Uma rede onde malucxs conversam, jogam bola, mandam emails, discutem e fazem as pazes, filosofam sobre vida e morte, colaboração, apropriação de tecnologia, como as coisas são por dentro, de onde viemos e para onde vamos.

Aviso de utilidade pública: Não nos responsabilizamos pelas modificações causadas nos seus neurônios após o convivio (prolongado ou não) com esta comunidade. Use com moderação.

Se apesar de todos esses avisos você ainda está à procura de pessoas que fazem MetaReciclagem, o mais fácil é cadastrar-se na lista de discussāo. Você também pode consultar o histórico da lista ou navegar por este site para descobrir mais. Ainda pode encontrar Esporos e ConecTAZes ou explorar o wiki

Para enviar uma mensagem, use o formuläro de contato.

53899 leituras

Figura 3. Proposta MetaReciclagem de Apropriação Tecnológica para Transformação Social. Disponível em: http://rede.metareciclagem.org/ Acesso em 15 fev. 2010 
O recorte temporal para coleta de dados quantitativos corresponde ao período de 2005 a 2010. A ferramenta de identificação utilizada para registro e coleta dos dados quantitativos de posts na lista de discussão foi do MetaReciclagem foi o $\mathrm{GMANE}^{28}$ que registra o número de posts e conversações diárias ocorrida na lista ao longo dos dias e meses do ano.

É importante ressaltar que não foi feita a análise qualitativa do total de posts na lista da Rede MetaReciclagem totalizando 33.975 (no recorte temporal mencionado), deixando tal ação para ser alcançada por meio de pesquisas posteriores. A apresentação dos dados quantitativos da pesquisa por meio de gráficos tem como objetivo único dar a conhecer o leitor a frequência e o movimento da conversação entre os membros da Rede MetaReciclagem ao longo dos anos.

\subsubsection{Técnica de Coleta de Dados Qualitativos}

A abordagem qualitativa foi realizada por meio de intervenção na lista de discussão do MetaReciclagem http://www.metareciclagem.org apresentando especificamente a proposta de debate do tema de pesquisa.

O corpus coletado incluindo threads (fluxos de mensagens a partir de uma discussão), posts em blogs e e-mails apresenta o recorte temporal de 05/03/2010 a 22/06/2010, período em que ocorreu a intervenção na lista de discussão. Ao todo, foram obtidos por meio da intervenção 44 conversações ou depoimentos, disponíveis na íntegra no Anexo 2 - Dados Coletados no Período de Intervenção na Lista de Discussão do MetaReciclagem. ( Dados disponíveis no CD que acompanha este relatório final de pesquisa). Podemos observar que o trabalho apresenta com corpus de análise as conversações sobre os membros cujo tema principal é a ação do MetaReciclagem ao longo dos anos na rede, bem como questionamentos e

${ }^{28}$ GAME: Software aplicado em listas de discussão que permite a visualização de posts e discussões ao longo do tempo. Disponível em: http://gmane.org/ Acesso em 17/07/2010. 
respostas a respeito de como a comunicação entre os membros do grupo foi capaz de impactar e agenciar as idéias "metarecicleiras" para fora do grupo.

Tabela 1. Esquema de Coleta de Dados

\begin{tabular}{|c|c|c|}
\hline Abordagem & Quantitativa & Qualitativa \\
\hline Objetivo & $\begin{array}{c}\text { Verificar a frequência de } \\
\text { conversação entre os } \\
\text { participantes da lista de } \\
\text { discussão do MetaReciclagem }\end{array}$ & $\begin{array}{l}\text { Aprofundar nos processos de } \\
\text { ação da Rede } \\
\text { MetaReciclagem e influências } \\
\text { em Políticas Públicas }\end{array}$ \\
\hline Fonte & http://rede.metareciclagem.org/ & http://rede.metareciclagem.org/ \\
\hline Números & 33.975 posts & 44 depoimentos coletados \\
\hline $\begin{array}{l}\text { Recorte } \\
\text { Temporal }\end{array}$ & $\begin{array}{c}2^{\circ} \text { semestre de } 2005 \text { a } 1^{\circ} \\
\text { semestre de } 2010\end{array}$ & 05/03/2010 a $22 / 06 / 2010$ \\
\hline $\begin{array}{l}\text { Ferramentas } \\
\text { Utilizadas }\end{array}$ & $\begin{array}{l}\text { GMANE } \\
\text { BROffice Calc. para a } \\
\text { tabulação dos dados }\end{array}$ & $\begin{array}{l}\text { Lista de Discussão, Twitter, e- } \\
\text { mails, blogs dos participantes } \\
\text { do MetaReciclagem. }\end{array}$ \\
\hline
\end{tabular}

Se observarmos o número de integrantes do MetaReciclagem no mês de junho de 2010 (509 pessoas) e o número de conversações coletadas na lista (44 conversações), observa-se que os dados coletados não constituem uma amostra representativa do número de integrantes da lista. Entretanto, o objetivo da pesquisa, ao primar por uma metodologia qualitativa foi coletar dados significativos para a investigação do objeto de pesquisa proposto, sendo, para esse fim, o corpus de pesquisa mais que suficiente para a realização da análise. Não foi feito nenhum corte ou seleção dos posts coletados. A participação dos integrantes foi considerada na íntegra. A proposta de intervenção para coleta do corpus qualitativo da pesquisa foi realiza na lista do MetaReciclagem, conforme apresentado no texto abaixo (retirado do site http://rede.metareciclagem.org/): 


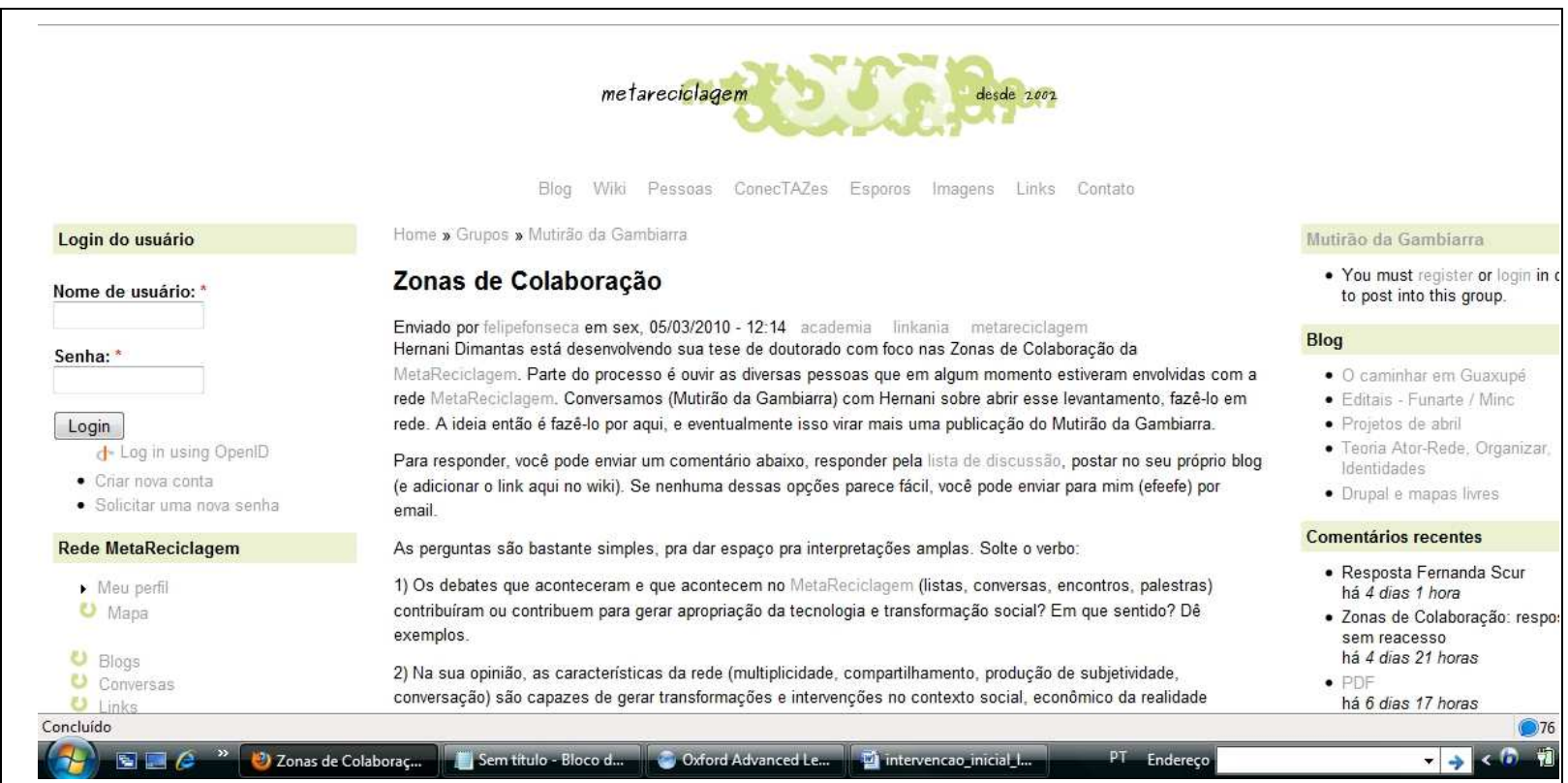

Figura 4. Imagem do Post de Intervenção na Lista de Discussão do MetaReciclagem. Disponível em: http://rede.metareciclagem.org/ Acesso em 15 fev. 2010

\section{Zonas de Colaboração}

Enviado por felipefonseca em sex. 05/03/2010 - 12:14

academia

linkania

$\underline{\text { metareciclagem }}$

Hernani Dimantas está desenvolvendo sua tese de doutorado com foco nas Zonas de Colaboração da MetaReciclagem. Parte do processo é ouvir as diversas pessoas que em algum momento estiveram envolvidas com a rede MetaReciclagem.

Conversamos (Mutirão da Gambiarra) com Hernani sobre abrir esse levantamento, fazê-lo em rede. A ideia então é fazê-lo por aqui, e eventualmente isso virar mais uma publicação do Mutirão da Gambiarra. Para responder, você pode enviar um comentário abaixo, responder pela lista de discussão, postar no seu próprio blog (e adicionar o link aqui no wiki). Se nenhuma dessas opções parece fácil, você pode enviar para mim (efeefe) por email.

As perguntas são bastante simples, pra dar espaço pra interpretações amplas. Solte o verbo:

1) Os debates que aconteceram e que acontecem no MetaReciclagem (listas, conversas, encontros, palestras) contribuíram ou contribuem para gerar apropriação da tecnologia e transformação social? Em que sentido? Dê exemplos.

2) Na sua opinião, as características da rede (multiplicidade, compartilhamento, produção de subjetividade, conversação) são capazes de gerar transformações e intervenções no contexto social, econômico da realidade brasileira? Como? Dê exemplos.

Por favor, faça o login ou registre-se na lista para poder enviar comentários.

1.146 leituras. 
A pesquisa também realizou intervenções no Twitter nos meses de Março e Abril de 2010, utilizando posts através do Twitter do pesquisador, conforme as postagens abaixo, para disseminar o debate, redirecionando o link para a lista de discussão do MetaReciclagem.
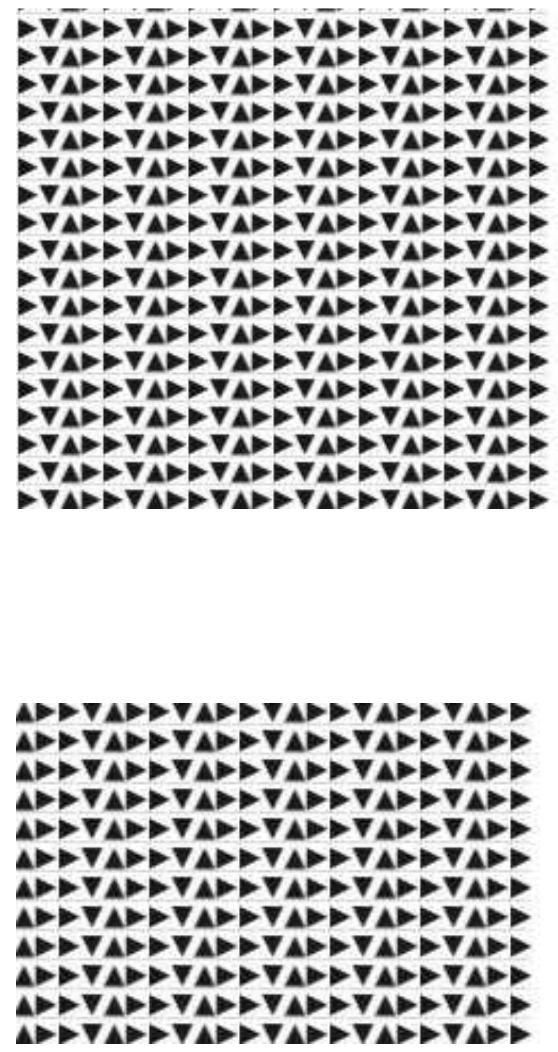

@dadarquia opas... a pesquisa eh colaborativa :)

http-//rede metareciclagem.org/wiki/Zonas-de-Colaboração

\section{\#boralah}

quarta-feira, 10 de março de 2010 07:51:21 via Echofon in reply to dadarquia:

\#metarecs gentileza gera gentileza http://rede metareciclagem org /wiki/Zonas-de-Colaboração

4.58 PM Mar 9th via Echofor

\#metarecs gentileza gera gentileza http://rede metareciciagem.org /wiki/Zonas-de-Colaboração

4.58 PM 1:ar 9th via Echofon quero entender como os \#metarecs definem o \#metareciclagem. alguém me ajuda?

1:32. PM Apr 29th via Echofon

quero entender como os \#metarecs definem o \#metareciclagem... alguém me ajuda?

1.32 PM Apr 29th via Echofon

Figura 5. Postagens no Twitter sobre a Intervenção na Lista do MetaReciclagem

O método de análise utilizado para a aplicação no corpus da pesquisa formado pelos depoimentos e conversações on-line foi a Análise de Conteúdo. De acordo com Silverman (2009, p. 149 ) a Análise de Conteúdo estabelece categorias pré-determinadas usadas para contar o conteúdo ou organizar expressões dos produtos coletados dos meios de comunicação. Trata-se um método útil para garantir a confiabilidade das suas medias, garantindo que diferentes pesquisadores o utilizem da mesma maneira. O método de Análise de Conteúdo também garante a validade dos achados por meio de contagem do uso de palavras ou definições de 
categorias a partir de trechos extraídos de um conjunto de textos que formam um corpus relevante para o tema pesquisado. A análise de conteúdo proporciona a redução e simplificação de grande quantidade de dados em segmentos organizados. Da mesma maneira, cabe ressaltar algumas limitações da técnica, dentre elas, a principal seria que por estabelecer um conjunto determinado de categorias, a análise temática desvia a atenção de atividades não-categorizadas do material coletado.

Inserida nas possibilidades de Análise de Conteúdo optou-se pela análise temática, baseada em unidades de registro. De acordo com Bardan (2009, p. 131):

Fazer uma análise temática consiste em descobri os "núcleos de sentido" que compõem a comunicação e cuja presença ou freqüência de aparição podem significar alguma coisa para o objectivo analítico escolhido. (...) O tema é geralmente utilizado como unidade de registro para estudar motivações de opiniões, de atitudes, de valores, de crenças, de tendências, etc. (BARDAN, 2009, p. 131).

A medida da intensidade, da ordem e da co-ocorrência em que cada elemento aparece é indispensável na análise dos valores (ideológicos, tendências) e das atitudes em relação ao tema de pesquisa proposto. De acordo com Bardan (2009), ainda é possível previamente determinar as categorias analisadas, bem como observar o surgimento de categorias importantes para o tema pesquisado durante a análise do material. O rigor na análise e pensamento indutivo são características que compõem a análise temática do corpus de pesquisa apresentado. O detalhamento a respeito da definição dos temas e categorias estão disponíveis no item 7 Resultados da Análise Temática do Conteúdo, deste relatório. 


\section{Dados Quantitativos do MetaReciclagem}

O ambiente virtual (Site e Lista de Discussão) do MetaReciclagem http://rede.metareciclagem.org possui uma série de dados relevantes de serem explorados, principalmente se observamos as trocas de posts ou mensagens entre os participantes no decorrer dos anos.

Desde o ano de 2005 (a partir do segundo semestre) os dados do MetaReciclagem vêm sendo monitorados pelo sistema GMANE ferramenta de software livre capaz de registrar o número de posts trocados na lista e suas respectivas datas. A partir das informações quantitativas obtidas no ambiente virtual foram observadas as possíveis formações de Zonas de Colaboração, zonas que também se configuram a partir da concentração da troca de posts entre os participantes ao longo dos anos.

Estas trocas culminaram, ao longo do tempo, em projetos espalhados pelo Brasil (Esporos e ConecTazes), orientações em rede, questionamentos e ações colaborativas. Tal olhar sobre os dados quantitativos visa mostrar a ocorrência de interações ao longo dos anos no movimento do MetaReciclagem, o movimento dessa conversação ao longo dos meses do ano; e dar prosseguimento à investigação proposta neste trabalho de pesquisa: de que forma o processo de comunicação instaurado a partir do MetaReciclagem constituiu-se em Zonas de Colaboração entre os participantes que resultaram em ações de intervenção em situações e contextos sociais no Brasil?

A seguir, são apresentados os dados quantitativos extraídos do ambiente virtual e aqui expostos têm como objetivo complementar a pesquisa dando a conhecer aos leitores algumas características do movimento e das conversações que acontecem no MetaReciclagem ao longo dos anos. O recorte temporal aplicado foi de Agosto/2005 (período em que foi adotada a ferramenta GMANE) a Maio/2010 (período final para coleta de dados da tese, conforme cronograma inicial proposto para a presente pesquisa). Os dados quantitativos foram ordenados, tabulados e apresentados em forma de gráficos a partir desse trabalho de pesquisa, não estando disponíveis nessa consistência ou apresentação na Lista do MetaReciclagem. É 
importante mencionar para o leitor dessa pesquisa que, para título de variável apresentada, os termos "post" ou "conversas" ou as expressões "posts trocados" ou "conversas ocorridas" foram tomados como sinônimo na apresentação dos dados, principalmente na apresentação do número de posts trocados entre os membros do MetaReciclagem ao longo dos meses dos anos referidos.

\subsection{Membros do MetaReciclagem}

TABELA 2. Participantes da Lista de Discussão MetaReciclagem x Ano

\begin{tabular}{c|c|c}
\hline $\begin{array}{c}\text { Numero de } \\
\text { participantes } \\
2002\end{array}$ & $\begin{array}{c}\text { Número de } \\
\text { participantes em }\end{array}$ & $\begin{array}{c}\text { Número de } \\
\text { participantes em }\end{array}$ \\
& 2009 & 2010 \\
\hline 6 a 10 pessoas & 450 a 460 pessoas & 509 pessoas $^{*}$ \\
\hline \multicolumn{2}{c}{ Fonte: http://rede.metareciclagem.org/profile } \\
* Contagem de participantes realizada ate o dia 02/06/2010.
\end{tabular}

De acordo com a Tabela 2, o número de participantes da Lista do MetaReciclagem em seu ano de início, em 2002, variava entre 6 a 10 pessoas. Esses participantes foram os principais fundadores do movimento de conversação. Infelizmente não foi possível acompanhar o aumento do número de participantes do MetaReciclagem no período de recorte temporal proposto por essa pesquisa segundo semestre de 2005 a primeiro semestre de 2010. Somente em 2009 atentou-se para o número de membros do movimento que variava entre 450 a 460 pessoas. No primeiro semestre de 2010 o número de participantes na lista era de 509 pessoas.

O que é possível observar sobre o crescimento em grande proporção de membros ao longo do tempo é propor uma avaliação positiva da capacidade de o MetaReciclagem continuar atraindo pessoas ao longo dos anos por meio de uma proposta colaborativa de conversação em rede, cuja tendência temática de 
construção de um comum entre as pessoas vem sendo sintomática ao longo do tempo pelos temas abordados pelo grupo na rede. Um exemplo da importância dos temas propostos pelo grupo é a questão da MetaReciclagem - reciclagem de computadores e demais TICs - questão temática que vem agregando interesse de públicos diversos ao longo dos anos, desde o início da Internet no Brasil em 1996, tendo em vista do rápido processo de obsolescência de computadores e outras tecnologias de comunicação, principalmente os celulares.

A MetaReciclagem - no sentido de reuso e reciclagem de computadores - é apenas um dentre os temas de discussão do movimento ou lista do MetaReciclagem. O movimento se desdobrou ao longo dos anos, desde 2002, em discussões acerca da Internet no Brasil, em ações e projetos de MetaReciclagem que atuam fora do movimento, em discussões teóricas acerca das características e cultura em rede dos Internautas, em empresas, ONGs e em diversos eventos artísticos divulgados e realizados por integrantes do grupo.

\subsection{Postagens e Discussões na Lista do MetaReciclagem}

TABELA 3. Número de Postagens na lista do MetaReciclagem x Ano

\begin{tabular}{c|c}
\hline ANO & NÚMERO DE POSTAGENS \\
\hline $2005^{\star}$ & 2.353 \\
\hline 2006 & 9.055 \\
\hline 2007 & 7.539 \\
\hline 2008 & 5.730 \\
\hline 2009 & 9.298 \\
\hline $201{ }^{\star \star}$ & 2.630 \\
\hline TOTAL & 33.975 \\
\hline
\end{tabular}

Fonte: http://rede.metareciclagem.org

* Corresponde ao período 6 meses - de agosto a dezembro de 2005.

** Corresponde ao período de 5 meses - de janeiro a maio de 2010. 
Os dados quantitativos apresentados a seguir, bem como o número de posts por ano fora registrados e extraídos por meio do GMANE e encontram-se disponíveis no endereço:

http://permalink.gmane.org/gmane.politics.organizations.metareciclagem/36932 Acesso em Jun. 2010.

\subsection{Conversações no MetaReciclagem em 2005}

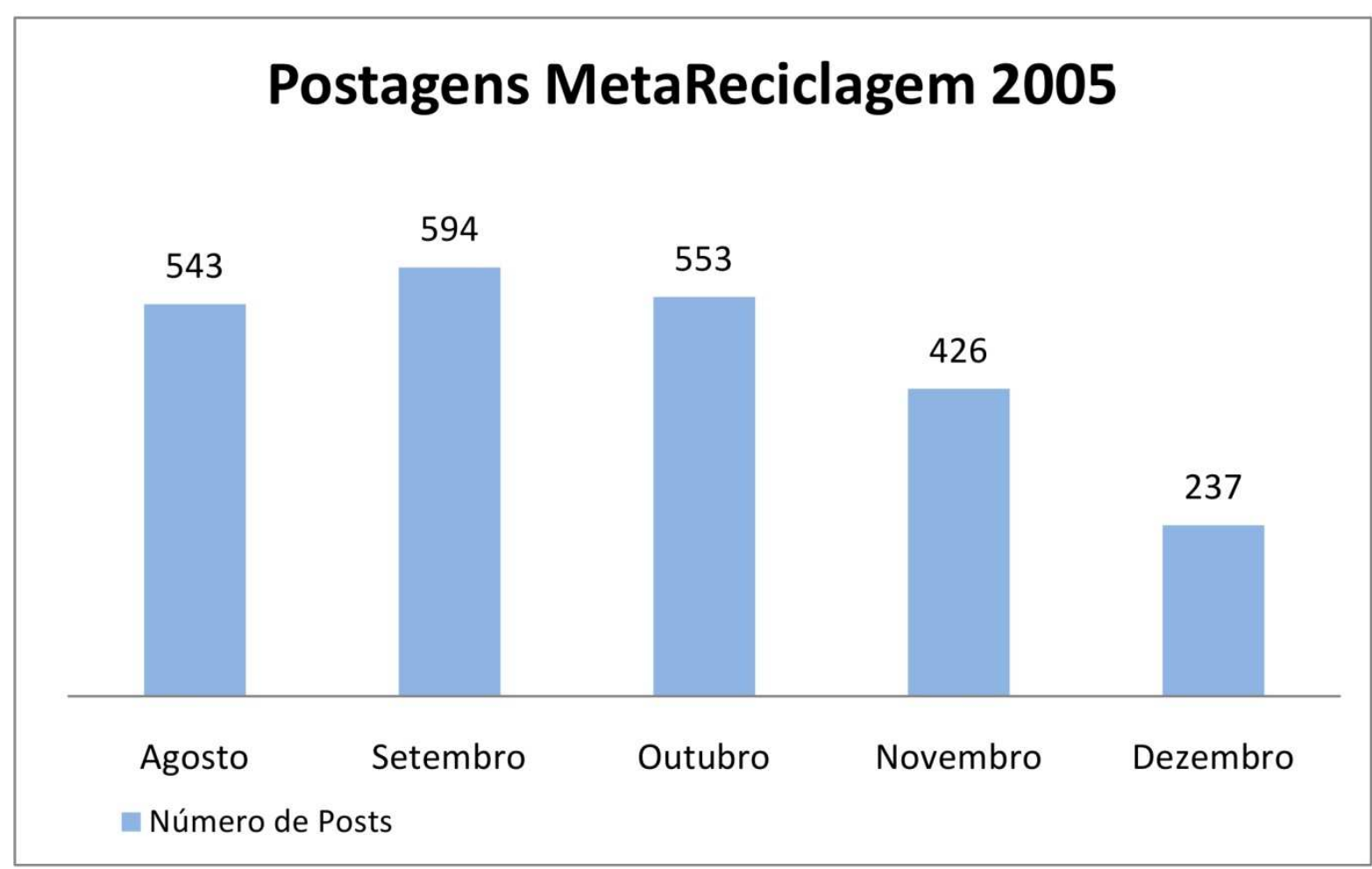

Figura 6. Gráfico do Número de Postagens na Lista de Discussão do MetaReciclagem por Mês em 2005.

Conforme a Figura 6 - Gráfico do Número de Postagens na Lista de Discussão do MetaReciclagem por Mês em 2005 - é possível observar que a partir do mês de agosto - recorte temporal período em que começou a se medir a atuação dos membros do MetaReciclagem no ambiente virtual http://rede.metareciclagem.org pode-se observar o número de total de posts no semestre: 2.353 posts trocados principalmente durante os meses de agosto/setembro/outubro/2005. 


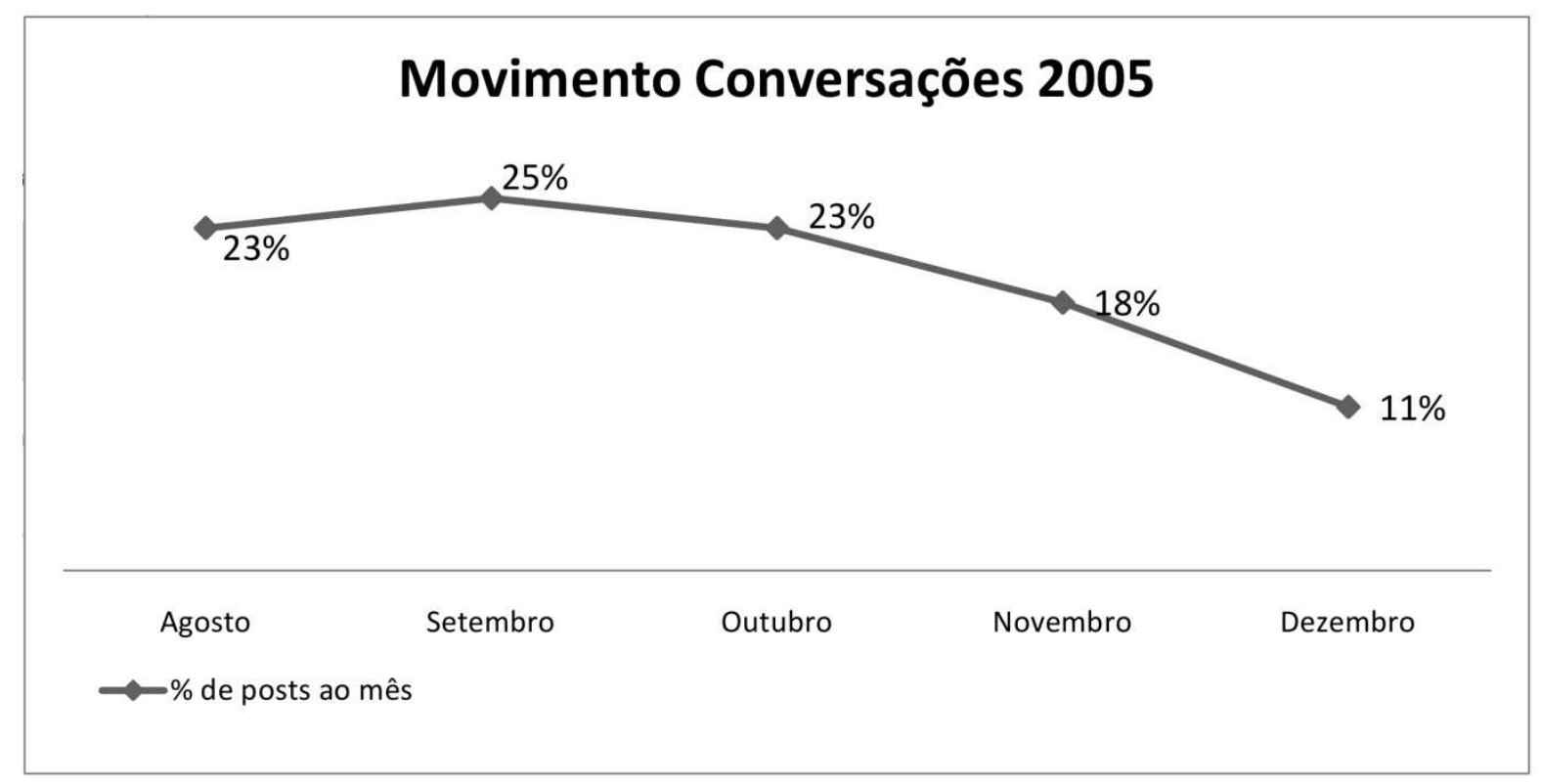

Figura 7. Gráfico do Movimento das Conversações na Lista do MetaReciclagem: porcentagens de troca de post ao mês a partir do segundo semestre de 2005.

$\mathrm{Na}$ Figura 7 - Gráfico do Movimento das Conversações em 2005: porcentagens de troca de posts ao mês. A percentagem apresentada em cada mês corresponde à respectiva parcela de posts por mês, conforme o Gráfico 6 (em página anterior) em relação ao total de posts do período (últimos cinco meses do anos de 2005). Observa-se o movimento das conversações ocorridas no segundo semestre de 2005 , culminando no mês de setembro com $25 \%$ dos posts trocados durante o período.

Os meses de agosto, setembro e outubro obtiveram $71 \%$ das trocas de mensagens. Podemos observar que esse foi o período em que os membros do MetaReciclagem mais interagiram no semestre e é provável que aí estejam acumulados alguns dos fatores ou assuntos, interesses em comum provocando movimentos de Zonas de Colaboração. 
6.4 Conversações no MetaReciclagem em 2006

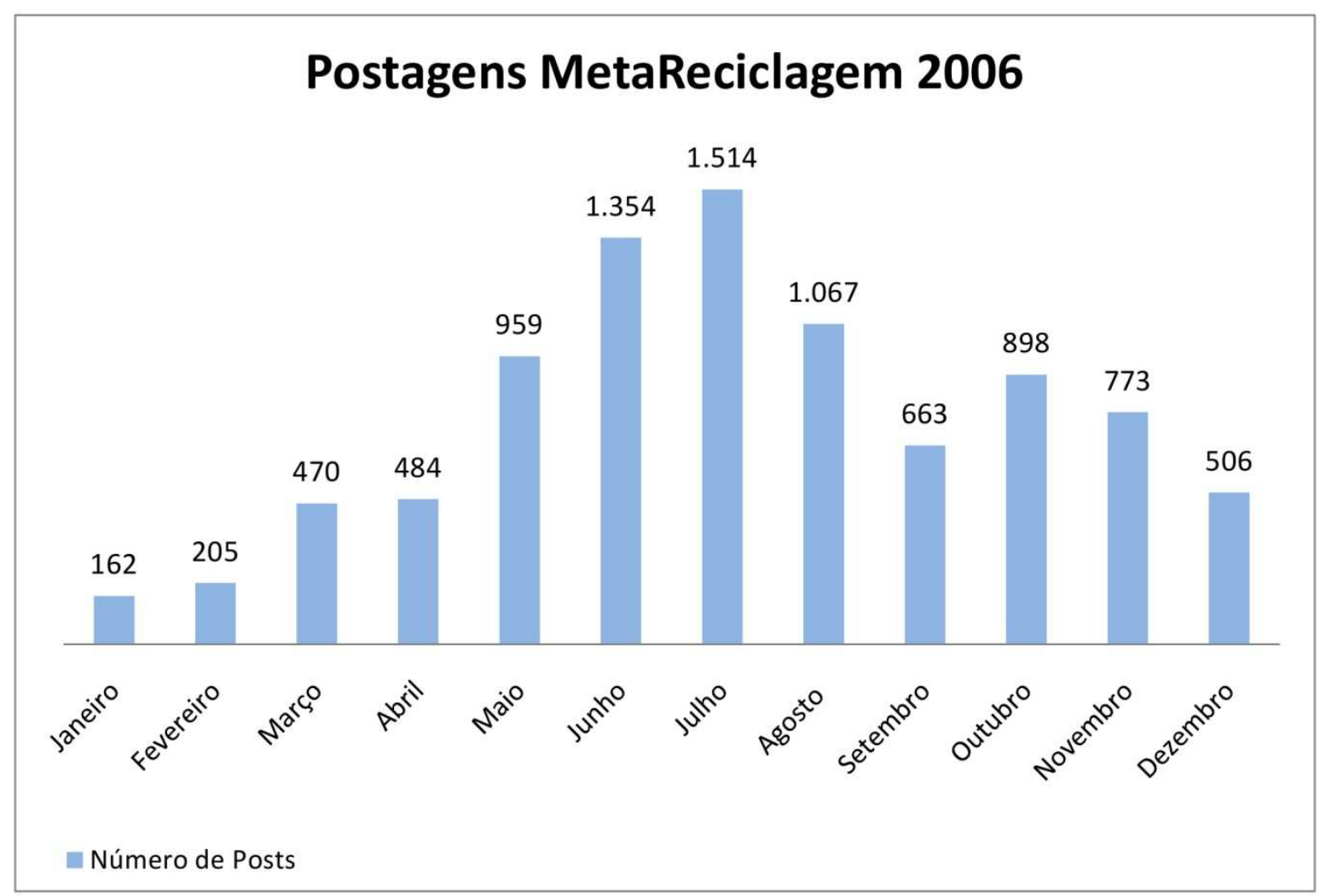

Figura 8. Gráfico do Número de Postagens na Lista de Discussão do MetaReciclagem por Mês em 2006.

No ano de 2006, conforme a Figura 8 - Gráfico do Número de Postagens na Lista de Discussão do MetaReciclagem por Mês - ocorreram 9.055 interações através de posts na lista de discussão entre os membros do MetaReciclagem.

Os meses com maior número de interações (acima de 1.000 interações trocadas) foram junho, julho e agosto com número de posts respectivamente 1.354, 1.514 e 1067 posts cada um. 


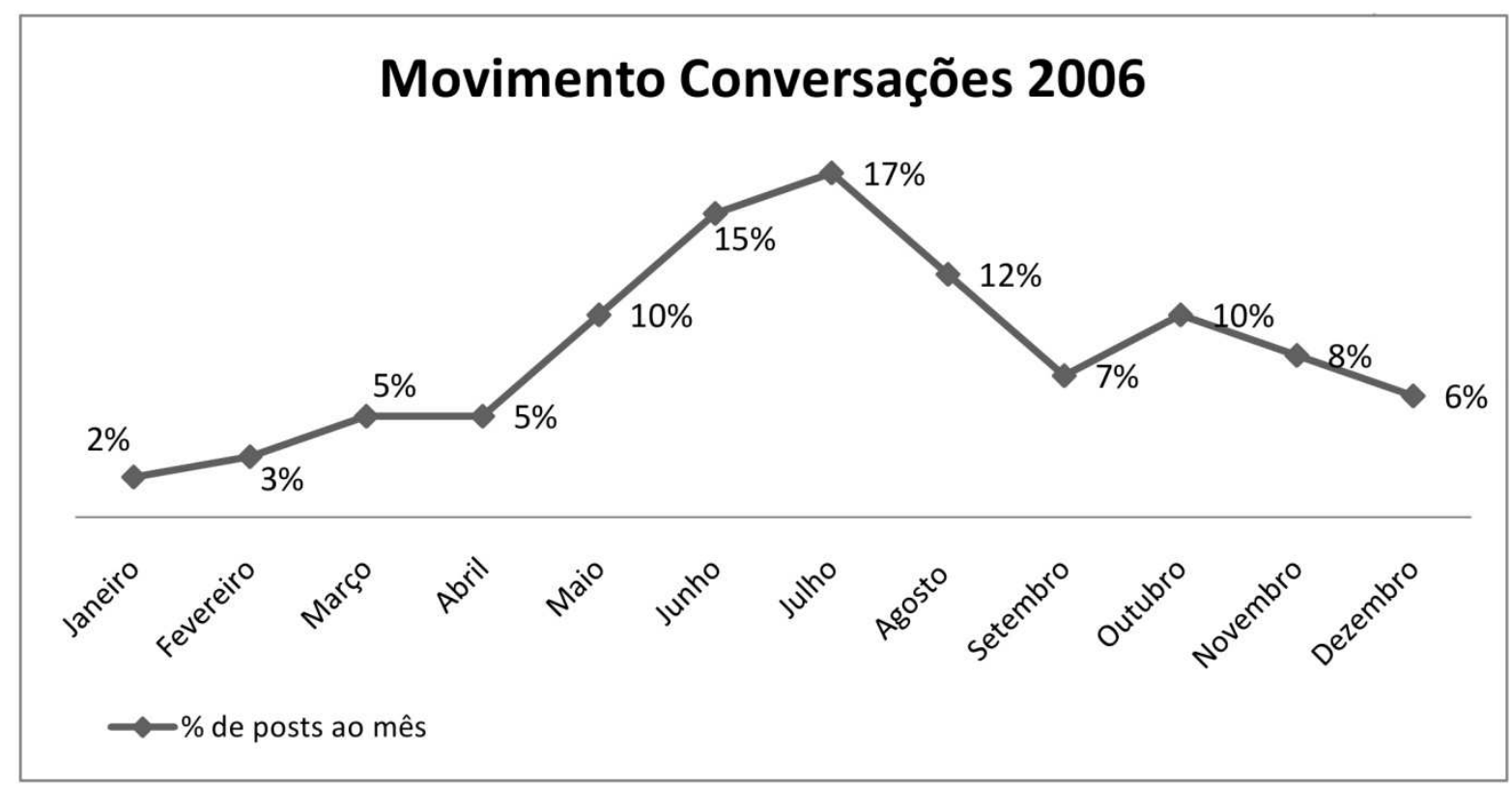

Figura 9. Gráfico do Movimento das Conversações na Lista do MetaReciclagem em 2006. $\%$ de posts ao longo dos meses em 2006.

No ano de 2006 foi possível obter todos os dados de postagem dos membros do MetaReciclagem relativos aos doze meses do ano. Pode-se perceber que em todos os meses do ano houve troca de mensagens via lista do MetaReciclagem ainda que em diferentes intensidades de interação.

Conforme observamos na Figura 9 - Gráfico do Movimento das Conversações, ao longo do ano de 2006, é perceptível o aumento da troca de posts de forma crescente entre os meses de maio/junho e julho. Ao todo, os três meses mencionados totalizam $42 \%$ dos posts trocados ao longo do ano, sendo que o mês de julho alcança o pico de $17 \%$ das trocas de conversações. A existência desses picos de conversação sugere a postagem de temas ou conversações cujo interesse poderia ser mais comum entre os participantes. 
6.5 Conversações no MetaReciclagem em 2007

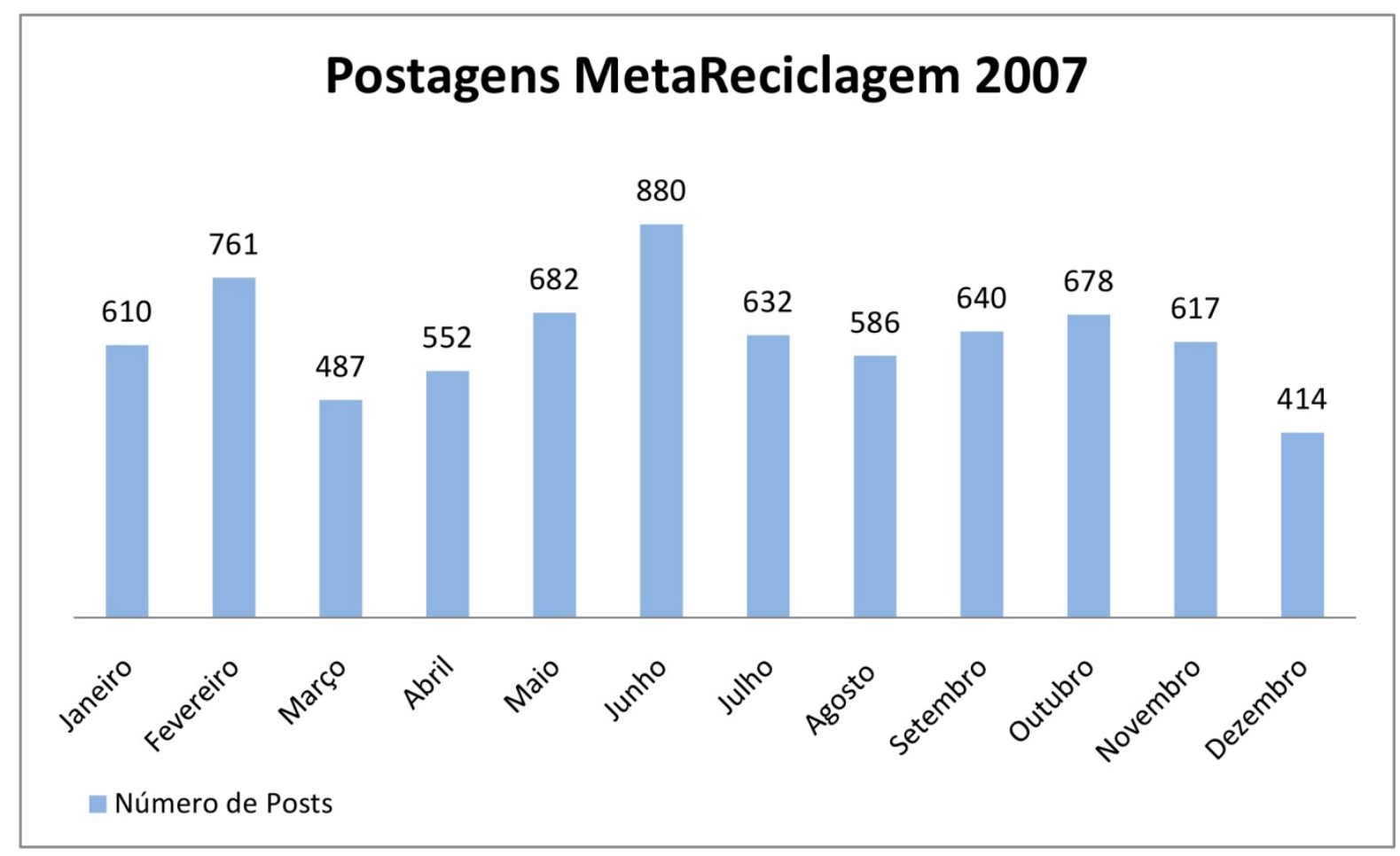

Figura 10. Gráfico do Número de Postagens na Lista de Discussão do MetaReciclagem por Mês em 2007.

No ano de 2007, as postagens na lista de discussão do MetaReciclagem aconteceram com maior regularidade de distribuição ao longo dos meses. Ao todo, 7.539 posts foram trocados no ano de 2007 entre os membros do movimento. Os meses de maior conversação foram fevereiro com 761 conversas e junho com 880 trocas de posts. 


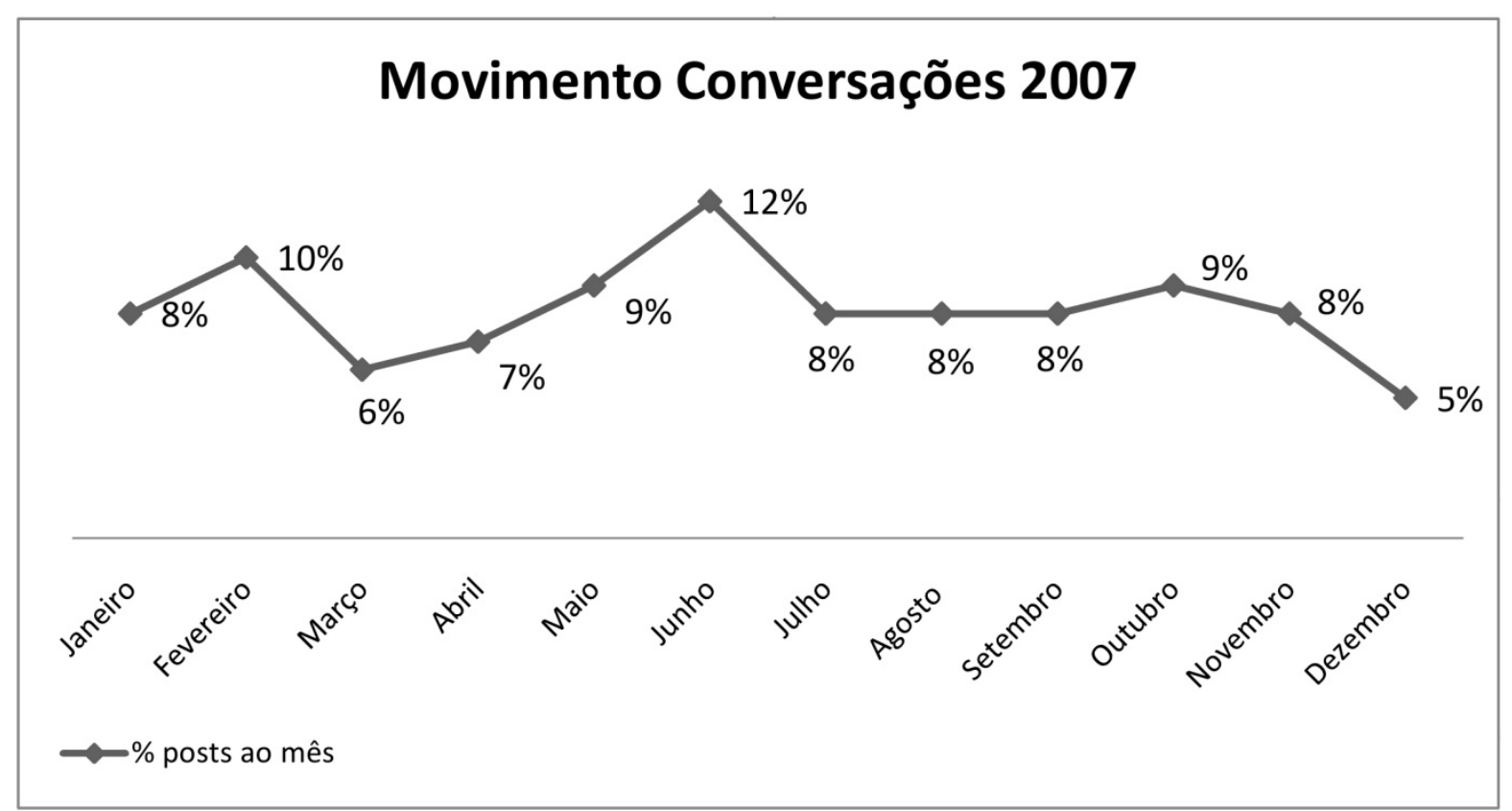

Figura 11. Gráfico do Movimento das Conversações na Lista do MetaReciclagem em 2007. $\%$ de posts ao longo dos meses em 2007.

Conforme a Figura 11, o movimento das conversações em 2007 apresenta-se de forma mais regular ao longo dos meses de 2007. Pode-se observar que o primeiro semestre acumulou a maior porcentagem em termos de troca de posts $52 \%$ para $46 \%$ no segundo semestre.

Os meses de fevereiro/2007 e junho/2007 representam os picos com o maior número de conversações ao longo do ano: $10 \%$ dos posts foram trocados no mês de fevereiro e $12 \%$ no mês de junho. 
6.6 Conversações no MetaReciclagem em 2008

\section{Postagens MetaReciclagem 2008}

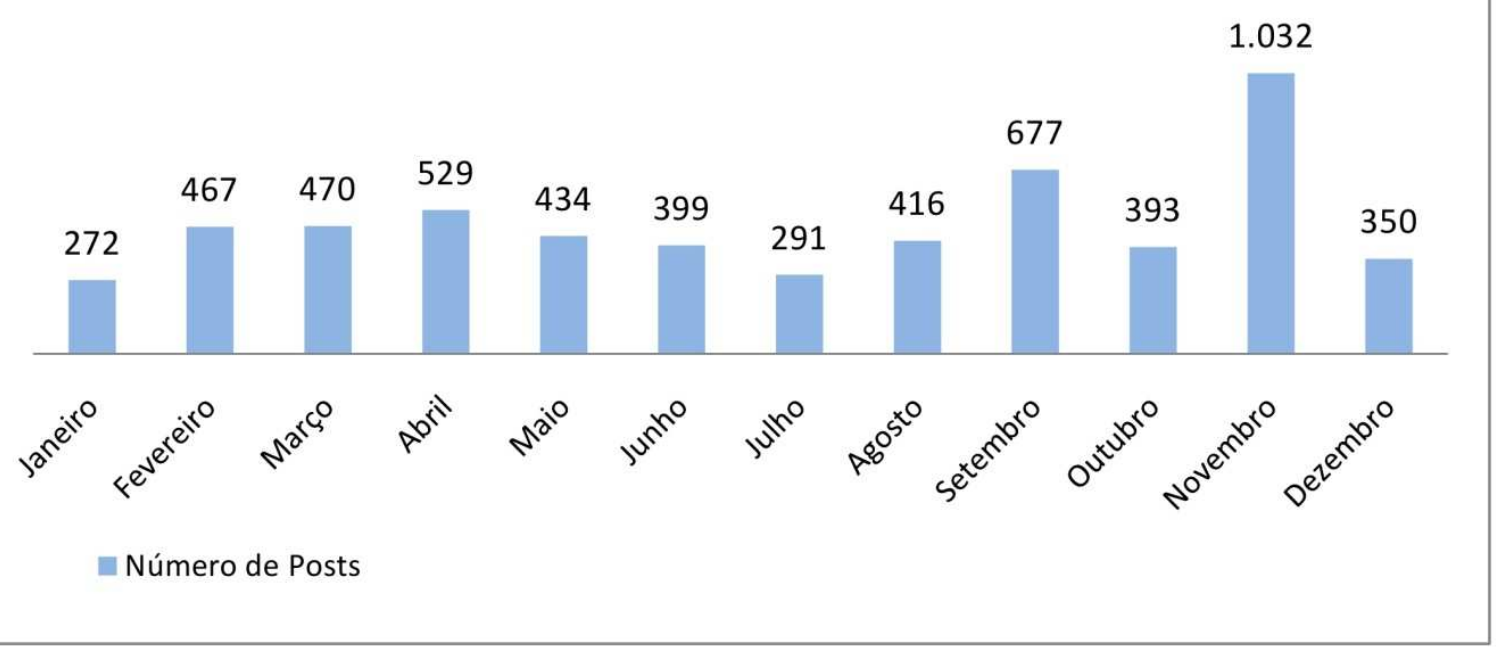

Figura 12. Gráfico do Número de Postagens na Lista de Discussão do MetaReciclagem por Mês em 2008.

Em 2008, o número total de conversações na Lista de Discussão do MetaReciclagem foi de 5.730 posts trocados. Nesse ano, o mês de novembro chama a atenção por concentrar, somente nele, 1.032 conversas trocadas. Em seguida, setembro com 677 posts de conversação entre os participantes.

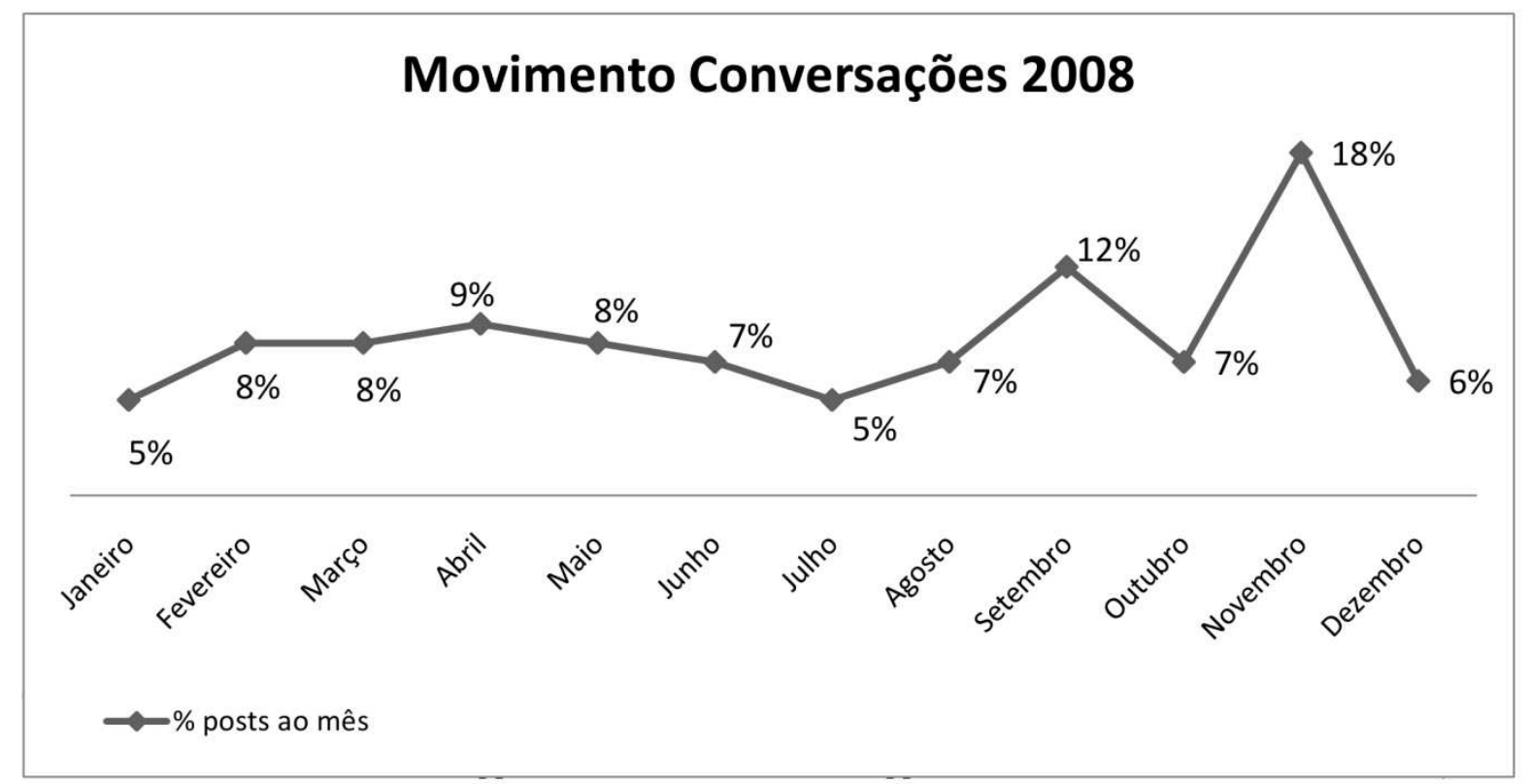

Figura 13. Gráfico do Movimento das Conversações na Lista do MetaReciclagem em 2008. $\%$ de posts ao longo dos meses em 2008. 
Ao observarmos a Figura 13 - Gráfico do Movimento das Conversações na Lista do MetaReciclagem em 2008, dois fatores chamam a atenção: a regularidade no porcentagem de troca de posts no primeiro semestre do ano variando entre $5 \%$ a $9 \%$ e, no segundo semestre, dois picos de conversações ocorridas nos meses de setembro com 12\% e novembro com 18\%. O segundo semestre de 2008 acumulou $55 \%$ das conversações ocorridas ao longo do ano.

\subsection{Conversações no MetaReciclagem em 2009}

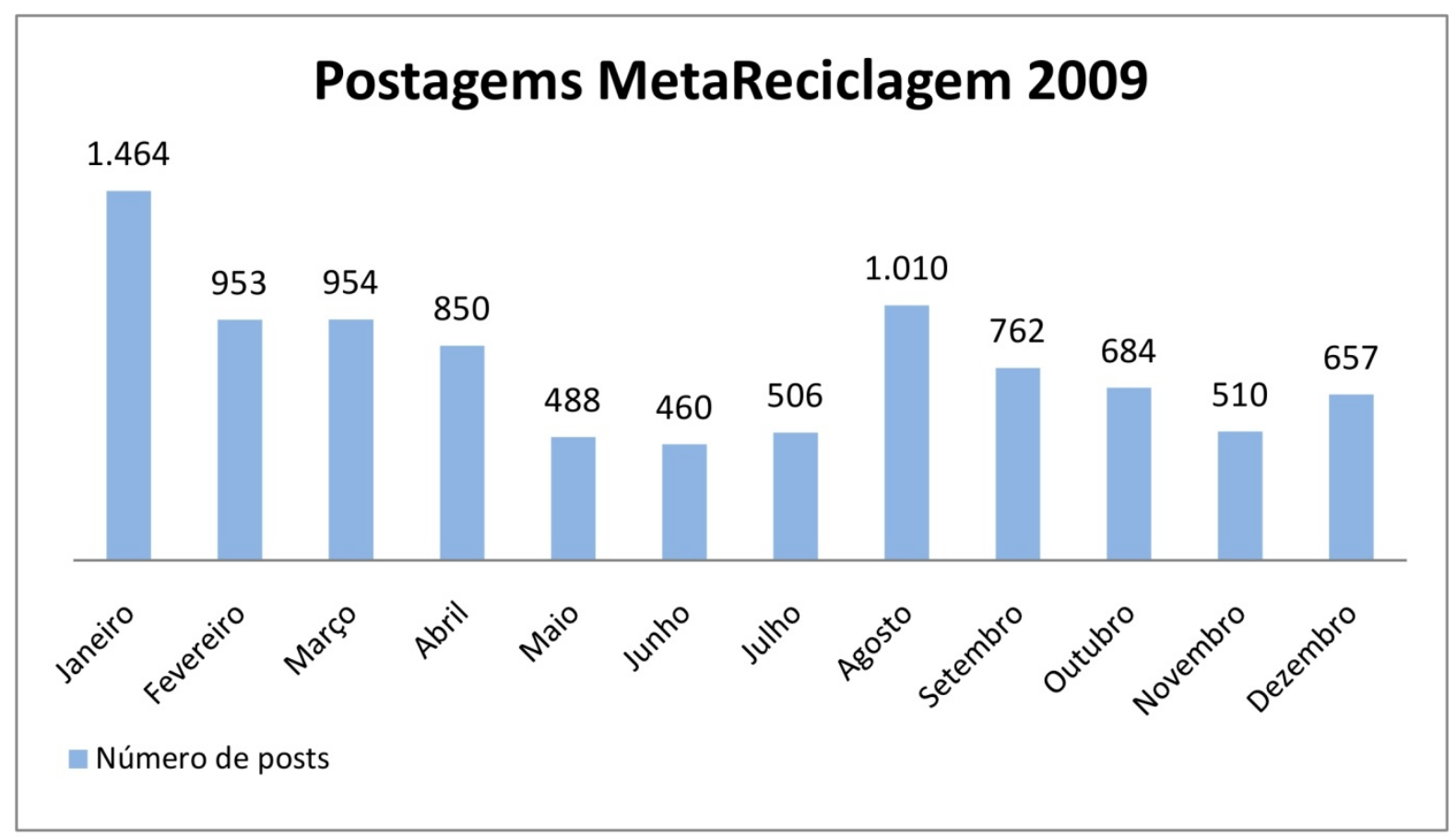

Figura 14. Gráfico do Número de Postagens na Lista de Discussão do MetaReciclagem por Mês em 2009.

Na Figura 14 - Gráfico do Número de Postagens na Lista de Discussão do MetaReciclagem por Mês em 2009, é possível observar que 9.298 posts foram trocados entre os participantes do movimento ao longo do ano. No período de recorte da pesquisa, o ano de 2009 pode ser considerado o ano em que ocorreu o maior número de troca de conversações via Lista do MetaReciclagem. 


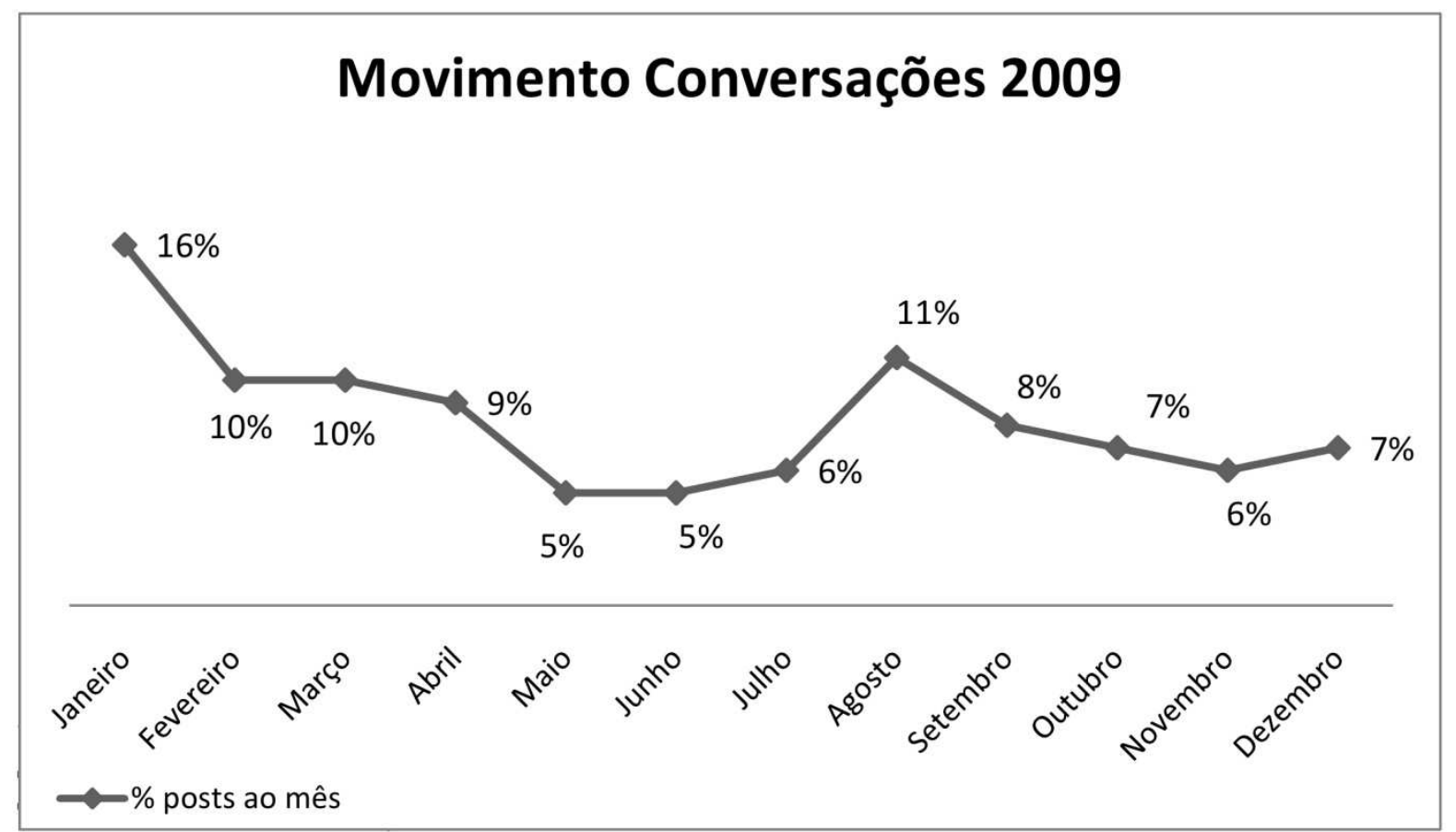

Figura 15. Gráfico do Movimento das Conversações na Lista do MetaReciclagem em 2009. \% de posts ao longo dos meses em 2009.

De acordo com a Figura 15 - Gráfico do Movimento das Conversações na Lista do MetaReciclagem em 2009 - o referente ano de 2009 inicia com um pico de conversação e troca de posts entre os membros da rede de $16 \%$, sendo os demais movimentos de conversação ocorrendo ao longo do restante dos meses do ano de maneira constante e sem variações significativas de frequência. 
6.8 Conversações no MetaReciclagem em 2010

\section{Postagens MetaReciclagem 2010 $1^{\circ}$ Semestre}

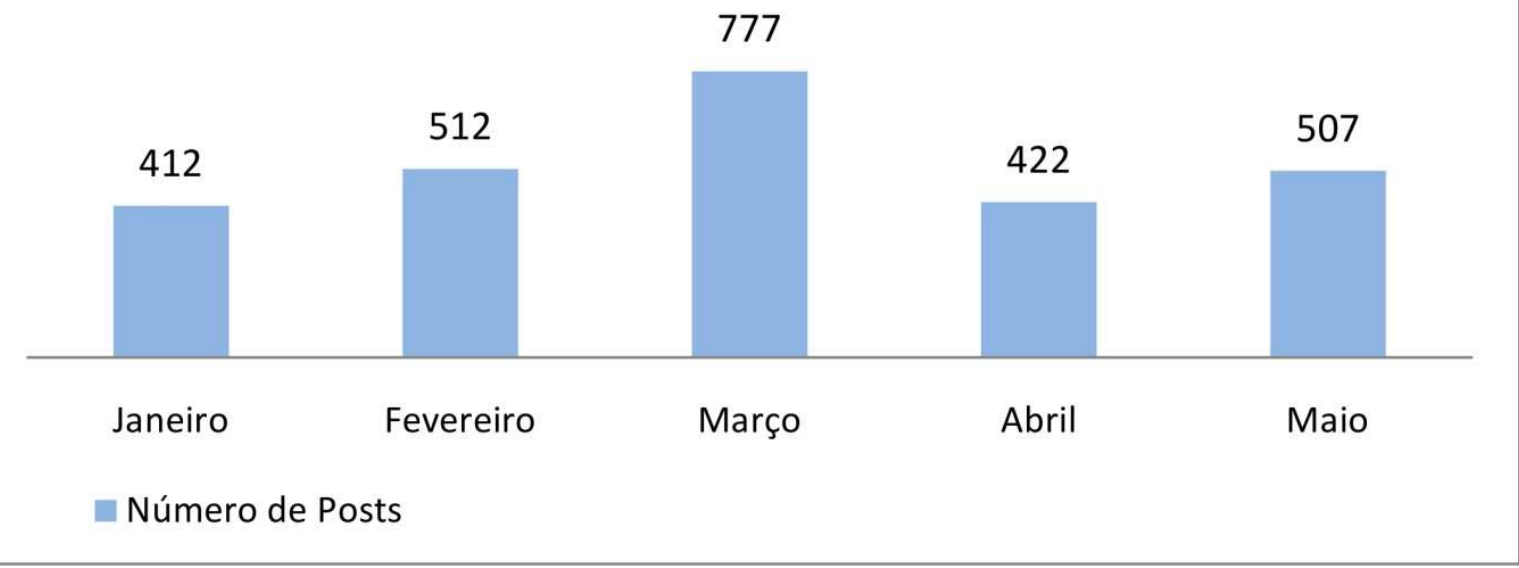

Figura 16. Gráfico do Número de Postagens na Lista de Discussão do MetaReciclagem por Mês em 2010 $1^{\circ}$ Semestre.

De acordo com a Figura 16 - Gráfico do Número de Postagens na Lista de Discussão do MetaReciclagem em 2010, o primeiro semestre apresenta um comportamento de troca de posts constante e, de certa maneira estável, com pequeno pico no mês de março de 2010. Ao todo, no primeiro semestre de 2010 foram trocados 2.630 posts entre os participantes da Lista de Discussão. 


\section{Movimento Conversações 2010}

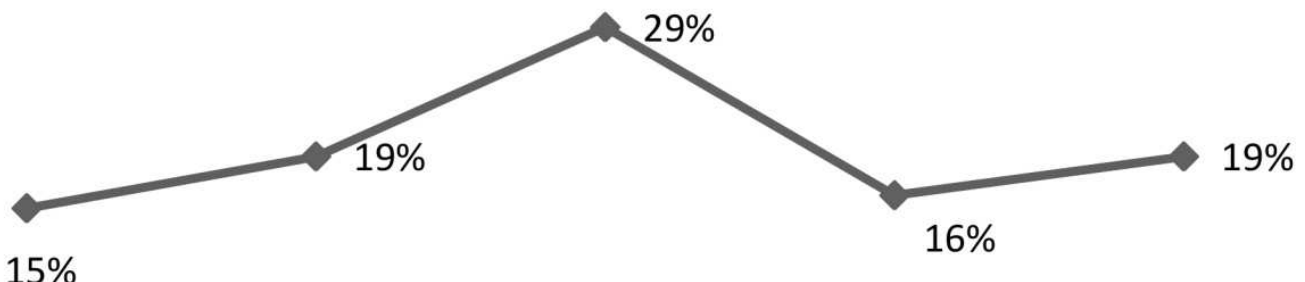

$15 \%$

$16 \%$

$\begin{array}{llll}\text { Janeiro } & \text { Fevereiro } & \text { Março } & \text { Abril }\end{array}$

$\sim \%$ posts ao mês

Figura 17. Gráfico do Movimento das Conversações na Lista do MetaReciclagem em 2010. $\%$ de posts ao longo de cinco meses do $1^{\circ}$ semestre de 2010.

\subsection{Total de Postagens MetaReciclagem 2005 a 2010}

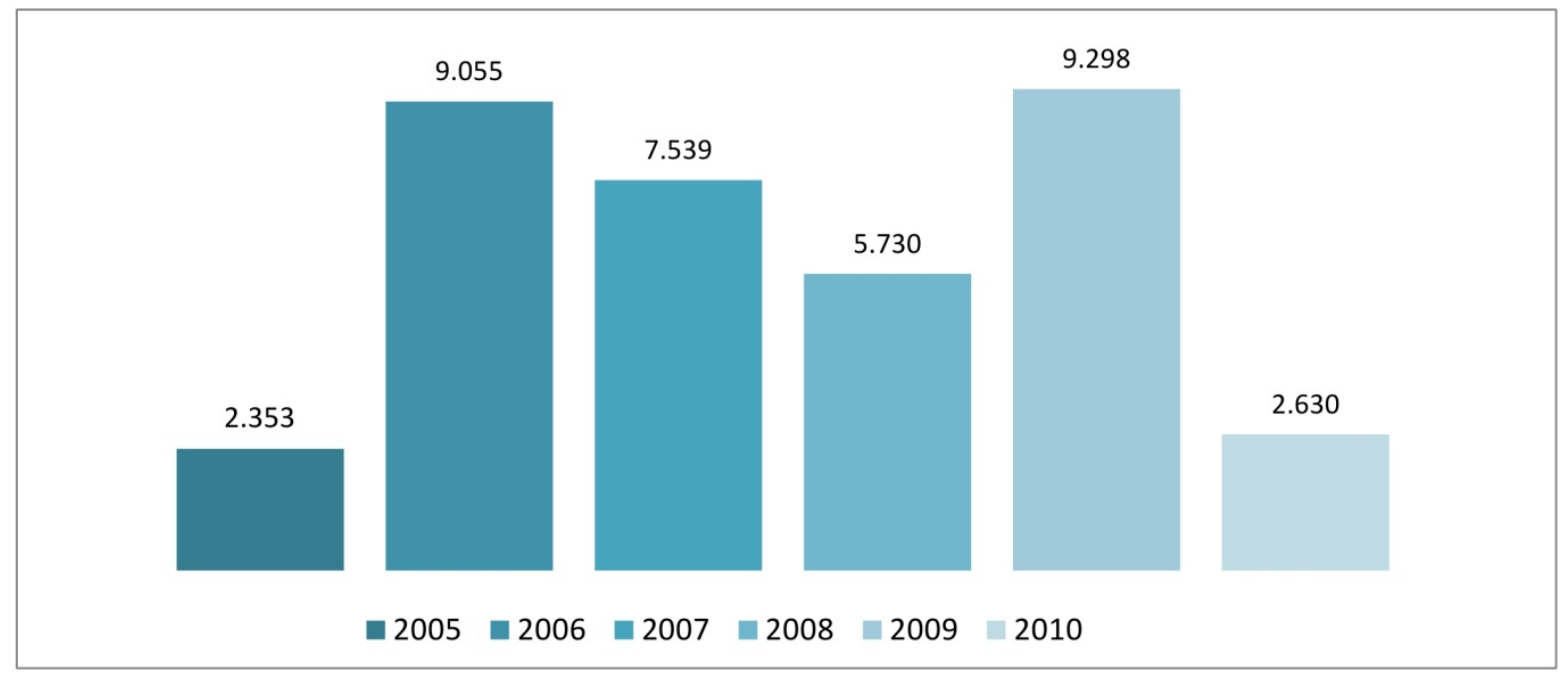

Fig.18 Postagens MetaReciclagem 2005 a 2010. Fonte: http://arquivos.metareciclagem.org/

* 2005: Corresponde ao período de agosto a dezembro de 2005.

**2010: Corresponde ao período de janeiro a maio de 2010. 


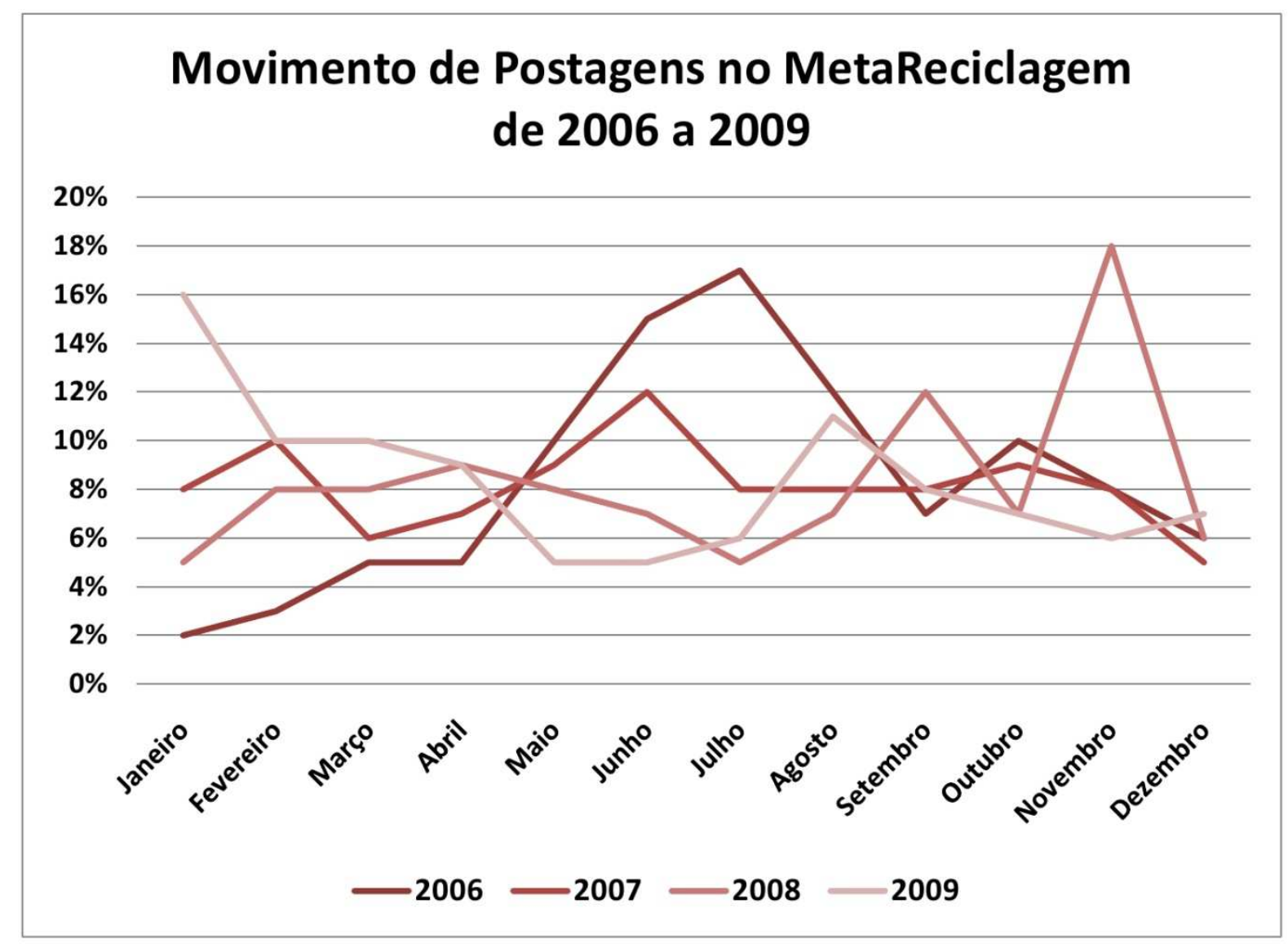

Figura 19. Gráfico do Movimento das Conversações na Lista do MetaReciclagem de 2006 a 2009 X $\%$ de posts ao longo dos anos.

Por meio de uma análise dos dados quantitativos apresentados tiveram como objetivo representar "momentos" ou, "estados" das conversas ocorridas ou "trocadas" em rede no MetaReciclagem ao longo do período de 2006 a 2009. Os períodos mensais de 2005 e 2010 não foram incluídos no gráfico por não representarem períodos anuais, mas apenas alguns meses do ano.

Observando a série histórica dos dados por ano, representativos das conversações, é possível perceber uma dinâmica de constante ao longo dos meses do ano no MetaReciclagem. A conversação ocorre sem interrupções, uma vez que em todos os meses dos anos mencionados foram registradas ocorrências de interações entre os membros em rede.

Ao reunir as informações foi possível perceber uma certa dinâmica de conversação que concentra-se, ao longo dos anos, entre os meses do segundo semestre, principalmente nos meses do segundo semestre de cada ano. Analisar a 
dinâmica interna dessa conversação, seus temas principais, não foi proposto como objetivo desse trabalho de pesquisa, sendo todavia um objeto de interessante investigação em pesquisas futuras sobre o MetaReciclagem. Entretanto, algumas hipóteses foram levantadas para esse fenômeno, dentre elas está o fato de que é em agosto que se inicia o ano letivo americano e que, por isso, pode-se dizer que devido ao aumento no número de palestras e eventos é possível que haja maior interação entre os membros do movimento, por meio de novidades. É possível dizer que a partir das conversas realizadas, ações efetivas na realidade social aconteceram. Para os integrantes do movimento em rede, essas ações têm nomes e características definidas: são denominados Esporos ou ConecTAZes.

\subsection{Esporos}

Um esporo é um espaço auto-gestionado de referência, desenvolvimento e replicação fruto do movimento MetaReciclagem. Não necessariamente precisam de um local físico para se constituírem, entrentanto, observamos o registro de Esporos em diversas localidades do Brasil. Estas localidades foram documentadas pelo próprio movimento do MetaReciclagem

O foco dos Esporos não é o uso efetivo de estruturas metarecicladas para a criação de redes sociais, mas o planejamento, a pesquisa e a experimentação relacionados a estruturas da Rede MetaReciclagem.

Um esporo de MetaReciclagem precisa seguir alguns princípios, estabelecidos pelos coletivo:

- Auto-organização e autonomia (descentralização).

- Conhecimento livre.

- Hospitalidade e convivencialidade.

- Infrafísica aberta.

- Documentação em rede.

- Generosidade.

- Dinamismo. 
- Ímpeto criador.

- Socialização de cultura.

Em todo o Brasil, foram registrados no site do MetaReciclagem, até o ano de 2010, vinte e três Esporos cadastrados, alguns já com status de projetos encerrados. A vida útil de um Esporo depende de suas condições contextuais e culturais, não obedecendo a metas gerais, mas a condições específicas de cada região ou proposta de trabalho a ser desenvolvida.

É importante mencionar o surgimento das iniciativas de Esporos principalmente devido à metodologia de replicação proposta pela Rede MetaReciclagem e à possibilidade de abertura para outros tipos de projeto capazes de atuar como Esporos. Essas iniciativas podem ser consideradas resultantes das Zonas de Colaboração e do movimento de conversação no MetaReciclagem ao longo dos anos.

Abaixo, segue o mapa com os locais onde foram gerados Esporos a partir do movimento do MetaReciclagem no Brasil:

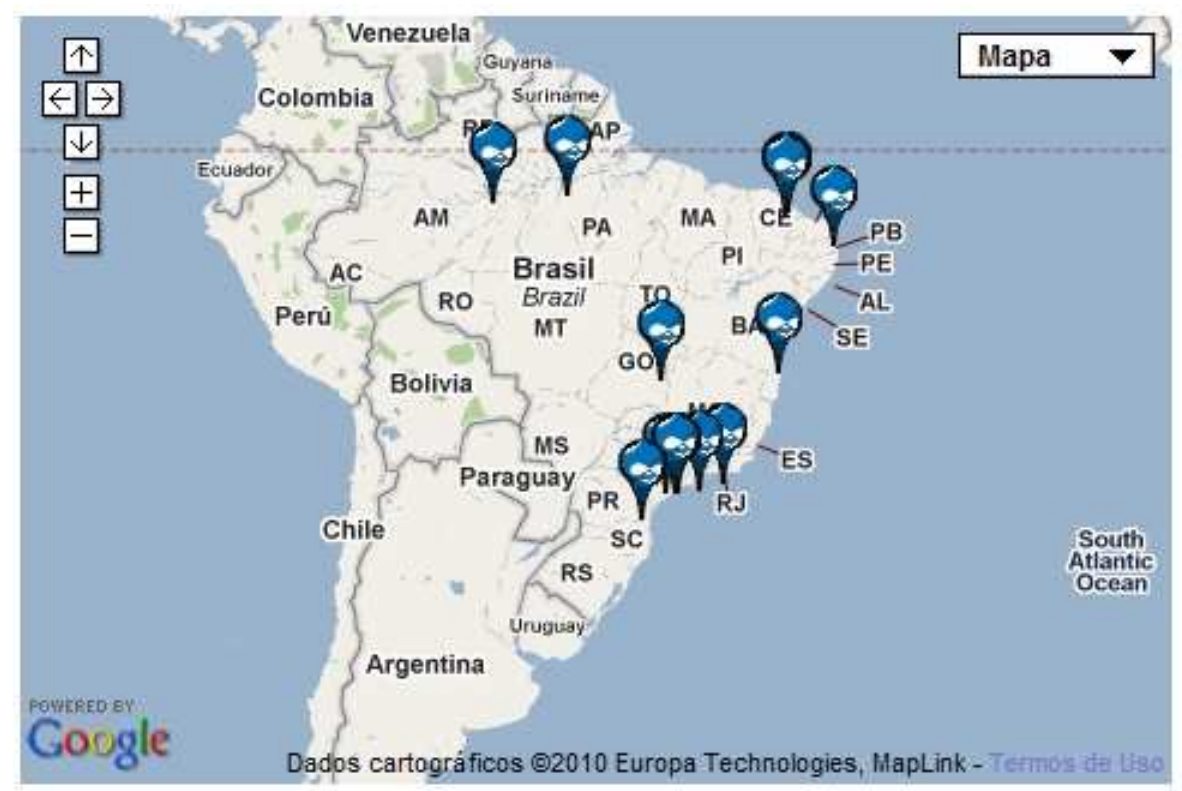

Figura 20. Mapa Esporos do MetaReciclagem no Brasil em 2010. Fonte: http://rede.metareciclagem.org 
Tabela 4. Lista dos Esporos no Brasil Cadastrados no Site da Rede MetaReciclagem até o $1^{\circ}$ Semestre de 2010.

\begin{tabular}{|c|c|}
\hline Esporos* & Data de Início \\
\hline Metaprojeto & 10/10/2009 \\
\hline Borala & $14 / 09 / 2008$ \\
\hline Bailux & 09/03/2009 \\
\hline Granja Portugal - Casa Brasil Fortaleza & $16 / 11 / 2008$ \\
\hline Projeto Puraquê & $24 / 11 / 2008$ \\
\hline Casa de Cultura Livre da MetaRec do Ceará & $15 / 05 / 2010$ \\
\hline Meta Arte & 02/02/2009 \\
\hline Imaginários & 22/02/2009 \\
\hline Casa Maluca & $13 / 03 / 2009$ \\
\hline Alavanca & $16 / 06 / 2008$ \\
\hline DiBoa & $12 / 09 / 2008$ \\
\hline MetaSorocaba & $30 / 09 / 2008$ \\
\hline Loucos por Bits & $23 / 10 / 2008$ \\
\hline UbaLab & 06/04/2010 \\
\hline pontao da eco & $10 / 06 / 2009$ \\
\hline JuntaDados & $07 / 01 / 2010$ \\
\hline Agente Cidadão & $10 / 06 / 2008$ \\
\hline Parque Escola & $10 / 06 / 2008$ \\
\hline Mezanino & $15 / 06 / 2008$ \\
\hline IP & $16 / 06 / 2008$ \\
\hline Sacadura Cabral & $16 / 06 / 2008$ \\
\hline MetaCampinas & $16 / 06 / 2008$ \\
\hline Casinha & $16 / 06 / 2008$ \\
\hline
\end{tabular}

* Dados atualizados e registrados pelo Movimento do MetaReciclagem. Disponíveis em: http://rede.metareciclagem.org/listas/esporos Acesso em 20/04/2010. 


\subsection{ConecTAZes}

A ConecTAZ, segundo Daniel Pádua (integrante da Rede MetaReciclagem) é uma maneira de descrever como a MetaReciclagem cria e ocupa espaços de acesso e compartilhamento de conhecimento.

Ao contrário do modelo de telecentro, a ConecTAZ não objetiva somente o acesso à Internet. Trata-se de uma intervenção que visa à dinamização de redes sociais de conversas, troca de conhecimento e mobilização, com base na utilização crítica de software livre e com a intenção de gerar conhecimento livre.

ConecTAZes podem ser permanentes ou temporárias, fixas ou móveis. O que diferencia uma ConecTAZ de um Esporo é o fato de que a primeira não precisa de um espaço fixo e permanente para acontecer.

Em outras palavras: uma ConecTAZ é qualquer projeto de MetaReciclagem: uma iniciativa que tenha por objetivo mobilizar pessoas com interesses em comum para atuar com apropriação de tecnologia, mas sem ansiar por existência fixa e permanente. ConecTAZES não necessariamente precisam de um espaço físico para emergir. A necessidade do espaço físico pode vir posteriormente, como decorrência da prória ConecTAZ.

No site da Rede MetaReciclagem, até o ano de 2010 foram registradas 34 ConecTAZes em funcionamento e em planejamento e $14 \mathrm{com}$ status de encerradas. Todas as ConecTAZes foram cadastradas por membros da MetaReciclagem, conforme tabela abaixo:

Tabela 5. ConecTAZes Registradas no Site do MetaReciclagem até o $1^{\circ}$ Semestre de 2010.

\begin{tabular}{c|c}
\hline ConecTAZes $^{*}$ & Data de Início \\
\hline Ativismo Digital & $21 / 03 / 2010$ \\
\hline Lixo Eletrônico & $13 / 03 / 2010$ \\
\hline
\end{tabular}




\begin{tabular}{|c|c|}
\hline (ad)versos & $25 / 01 / 2010$ \\
\hline Dpaduando & $24 / 11 / 2009$ \\
\hline ZASF & $24 / 11 / 2009$ \\
\hline $\begin{array}{l}\text { Encontrão Transdimensional de MetaReciclagem } \\
\text { Bailux Party }\end{array}$ & $16 / 09 / 2009$ \\
\hline OpenCinema Arraial & $15 / 08 / 2009$ \\
\hline Tempo Novo, Tempo Velho: Arapyau, Araymã & $12 / 08 / 2009$ \\
\hline MetaRecursos & $11 / 08 / 2009$ \\
\hline Infra Lógica & $05 / 08 / 2009$ \\
\hline Mídia Livre & $18 / 06 / 2009$ \\
\hline MetaNave & $22 / 04 / 2009$ \\
\hline Livro Livre & $23 / 03 / 2009$ \\
\hline GEDJA - Jogos e Animações Open Source & $19 / 02 / 2009$ \\
\hline LabMadá & $05 / 02 / 2009$ \\
\hline Minuano Digital- Associação Software Livre.Org & $23 / 11 / 2008$ \\
\hline Natal Livre & $04 / 11 / 2008$ \\
\hline Mutirão da Gambiarra & $16 / 06 / 2008$ \\
\hline Casas Brasil & $16 / 06 / 2008$ \\
\hline Cultura Digital - Minc & $16 / 06 / 2008$ \\
\hline Bricolabs & $16 / 06 / 2008$ \\
\hline SectioNine S.A.C. & $13 / 06 / 2010$ \\
\hline MicroReciclagem & $30 / 11 / 2009$ \\
\hline Ensaio Fotográfico "eu na rede" & $07 / 09 / 2009$ \\
\hline Novas Interfaces & $14 / 08 / 2009$ \\
\hline MagnificaT & $28 / 04 / 2009$ \\
\hline GYOML & $20 / 04 / 2009$ \\
\hline Corporate Track & $25 / 03 / 2009$ \\
\hline Rede Mexe & $06 / 02 / 2009$ \\
\hline Carnavento & $10 / 12 / 2008$ \\
\hline sub\#4 & $4 / 12 / 2008$ \\
\hline Documentário do Projeto Casa Brasil & $24 / 10 / 2008$ \\
\hline
\end{tabular}




\begin{tabular}{c|c}
\hline MetaLearning & $11 / 09 / 2008$ \\
\hline Itinerâncias & $26 / 08 / 2008$ \\
\hline Heterodesign & $07 / 08 / 2008$ \\
\hline TV Teatro da Terra & $10 / 08 / 2009$ \\
\hline Ciclo Gambiarra & $06 / 05 / 2009$ \\
\hline Reciclando com Design & $03 / 05 / 2009$ \\
\hline Campus Party 2009 & $18 / 03 / 2009$ \\
\hline MíMiCa & $19 / 09 / 2008$ \\
\hline Oficinas Nômades & $07 / 08 / 2008$ \\
\hline Tribo Wiki & $26 / 06 / 2008$ \\
\hline Corrente Viva & $17 / 06 / 2008$ \\
\hline Autolabs & $16 / 06 / 2008$ \\
\hline Waag Sarai & $16 / 06 / 2008$ \\
\hline Digitofagia & $16 / 06 / 2008$ \\
\hline Sinapse Digital & $16 / 06 / 2008$ \\
\hline Neuromob & $16 / 06 / 2008$ \\
\hline Mídia Tática Brasil & $16 / 06 / 2008$ \\
\hline
\end{tabular}

* Dados atualizados e registrados pelo Movimento do MetaReciclagem. Disponíveis em: http://rede.metareciclagem.org/listas/conectazes Acesso em 20/04/2010.

Ao que sugere, as ConeTAZes cadastradas no site do MetaReciclagem ao longo dos anos são resultantes das conversações realizadas na lista e da troca de conhecimento e idéias. A Rede apresenta a possibilidade de cada participante estabelecer um projeto próprio, autônomo, de acordo com uma demanda local ou regional, a partir de uma metodologia de replicação e troca de conhecimentos entre dos participantes da MetaReciclagem. Acompanhando essa troca via lista, há anualmente projetos e reuniões, eventos presenciais, nos quais acontecem a troca de idéias e experiências presenciais entre os membros, o que torna o processo de disseminação do MetaReciclagem um processo comum em que, cada um dos membros, é capaz de desenvolver a sua própria rede Meta. 
Entretanto, estas idéias e conversações e as ações resultantes do movimento serão apreendidas de maneira mais próxima possível a partir da proposta de análise temática efetuada nesta pesquisa do corpus que reuniu as mensagens trocadas na lista de discussão entre os membros da Rede MetaReciclagem sobre o tema de investigação: uma reflexão das ações do MetaReciclagem ao logo dos anos na rede e a influência em políticas públicas no Brasil; ambos presentes no capítulo seguinte. 


\section{Resultados da Análise Temática do Conteúdo}

A partir da técnica Análise de Conteúdo, e inserida nessa técnica, a análise temática categorial de expressão de acordo com Bardan (2009, p. 245), foi possível extrair do corpus de pesquisa - ao todo 44 mensagens trocadas entre os participantes da lista do MetaReciclagem - cinco categorias principais de análise.

As cinco categorias principais também foram estabelecidas a partir das hipóteses levantadas na pesquisa, posto que as hipóteses constituem-se, desde o início da investigação, em instrumentos norteadores que apontam para possíveis soluções ou, até mesmo, para o aprimorando do questionamento inicial proposto neste trabalho de pesquisa que pode ser abreviado através da pergunta: o processo de comunicação na Rede MetaReciclagem criou Zonas de Colaboração que permitiram ações de intervenção em situações e contextos sociais no Brasil?

Abaixo, seguem as categorias principais de análise da pesquisa:

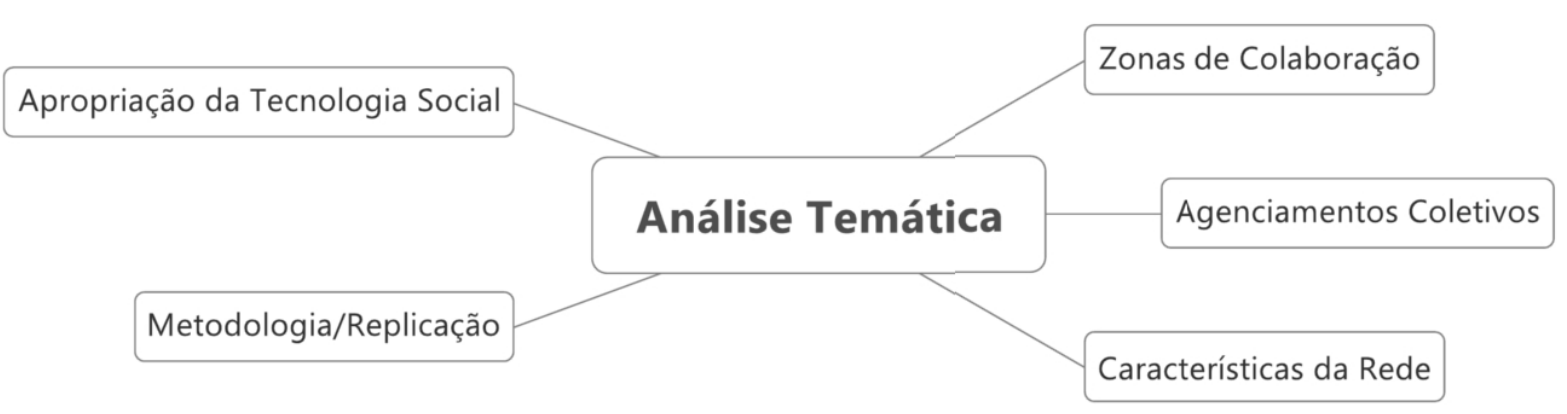

Fig. 21 Gráfico das Categorias Principais de Análise de Conteúdo Temática

As cinco categorias principais incorporam unidades de registro, frases, expressões, que foram classificadas segundo as ocorrências de frequência nas conversas dos integrantes do MetaReciclagem, segundo os seguintes critérios:

- Zonas de Colaboração: estão incluídas nessa categoria todas as expressões e "falas" referentes à conversação, ao diálogo efetuado na rede MetaReciclagem e como consequência a potência gerada a partir 
dessas conversações, bem como referências ao sentimento de pertendimento e à ação em multidão.

- Agenciamentos Coletivos: nessa categoria encontram-se todos os exemplos de projetos, relatos de experiências pessoais e transformações sociais, bem como o relato sobre o surgimento de parcerias que se desenvolveram ao longo dos anos a partir da Rede MetaReciclagem.

- Características da Rede: estão incluídos nessa categoria todos os comentários dos participantes do MetaReciclagem sobre a Internet e suas caracteríticas, com o propósito de identificar quais característas da Internet, na opinião dos membros do movimento, facilitaram a ação do MetaReciclagem ao longo dos anos.

- Apropriação da Tecnologia Social: nessa categoria foram incluídas as expressões e relatos, bem como conceito sobre o que é apropriação da tecnologia social e como essa ação de apropriação ou o seu processo é compreendido por meio dos participantes do MetaReciclagem.

- Metodologia/Replicação: foram incluídas, nessa categoria, as menções e expressões que tratam exclusivamente da metodologia de replicação do MetaReciclagem. Essa categoria foi incluída devido à hipótese de que a metodologia se constitui em um dos aspectos centrais pelo qual projetos e intervenções gerados a partir da Internet são capazes de se difundir e alcançar outros espaços de atuação na sociedade.

O processo de classificação de acordo com o método e a técnica escolhidas pode ser observado nos Anexo 1 e 3, respectivamente: Corpus Qualitativo de Pesquisa e Análise Temática de Conteúdo; Matriz Bruta de Análise Temática e Categorização (ambos os anexos disponíveis no CD que acompanha o presente relatório). Nos anexos, está registrada a aplicação da metodologia bem como 
efetuada a separação das expressões por meio das categorias principais estabelecidas.

Ao observarmos o trabalho de emprego da técnica de análise qualitativa escolhida na matriz de dados brutos (Anexo 3) é fácil nos perguntarmos porque determinadas expressões foram inseridas em uma categoria ao invés de outra. Justificam-se as decisões do pesquisador a partir do que denominou Bardan (2009, p. 249) de variáveis de inferência definidas pelos indicadores:

a) Construção da frase.

b) Ordem das palavras.

c) Escolha das palavras.

d) Conotações das palavras.

e) Reticências, denegação, afirmações de boa-fé, exatidões inúteis, qualificativos, generalizações.

Tais indicadores fazem parte do exercício de aplicação da técnica de coleta de dados e compõem o efeito das expressões que, à medida que estão sendo analisadas pelo pesquisador as torna classificáveis dentro de categorias estabelecidas ou emergentes no processo. Outra consideração importante é dizer que nas principais categorias há níveis de intersecções que representam expressões ou pontos em comum com semelhanças de sentido tanto para os integrantes do MetaReciclagem quanto para o pesquisador, corroborando com as diversas possibilidades de classificação, que não invalidam a disposição criteriosa apresentada nesse trabalho de pesquisa.

O maior número de expressões apresentadas no corpus da pesquisa encontram-se inseridas na Categoria Agenciamentos Coletivos/Transformações. Ao todo foram encontrados 141 registros de ocorrências nessa categoria. Os termos ou expressões classificadas podem ser rapidamente visualizados por meio da nuvem de Tags (ou títulos), conforme abaixo: 
$\rightarrow$ Agenciamentos Coletivos/Transformações:

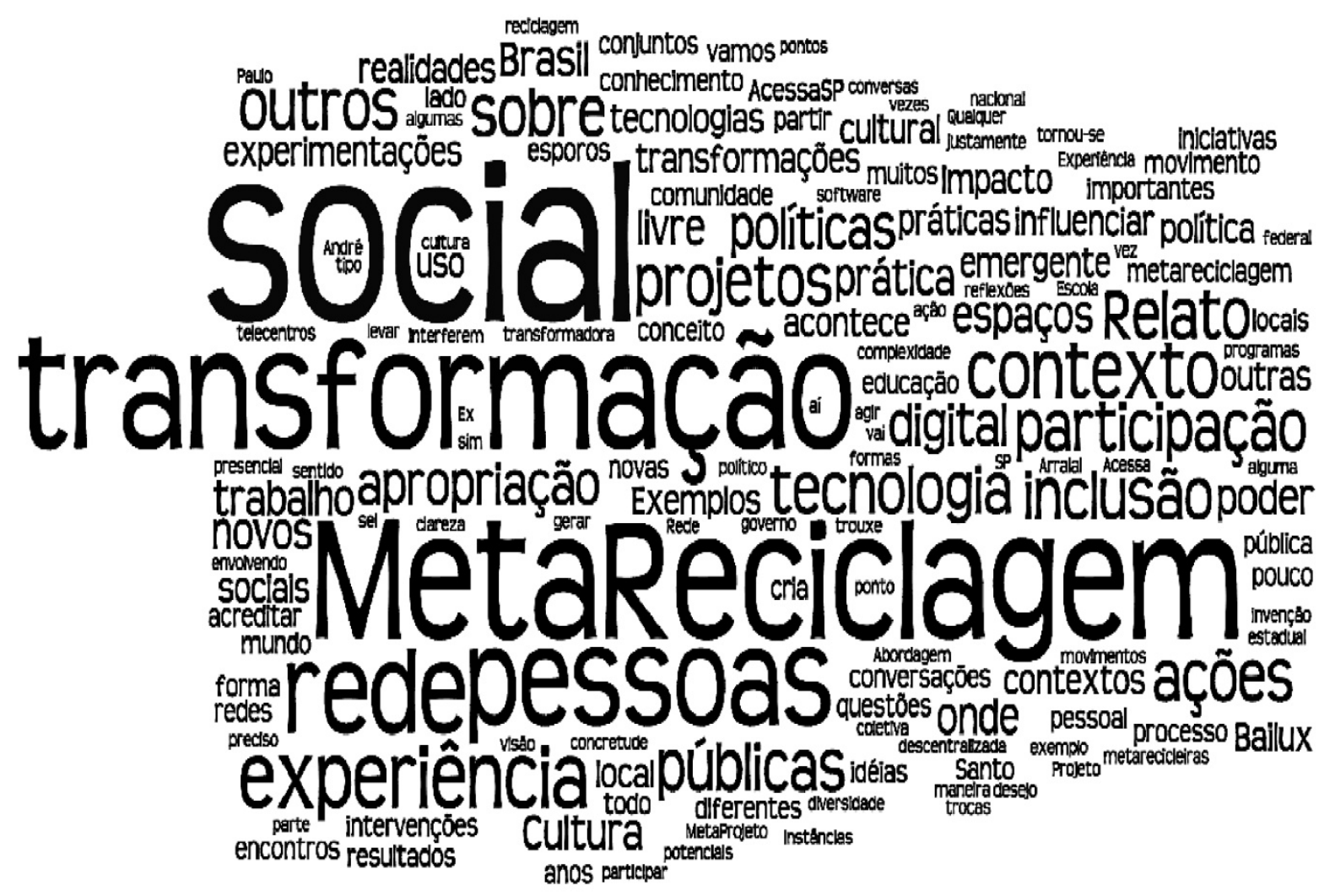

Fig. 22 Nuvem de Tags a Partir de Frases ou Expressões Classificadas na Categoria Agenciamentos Coletivos/Transformações. Ferramenta utilizada para essa visualização disponível em: http://www.wordle.net/create Acesso em 10 jun. 2010.

De acordo com a Figura 22 é possível observar a frequência dos termos transformação social bem como rede de pessoas e experiência que se destacaram nas frases dos Integrantes do MetaReciclagem que foram aqui. Tal configuração representa o modo como os integrantes do MetaReciclagem percebem as ações inseridas nos denominados Agenciamentos Coletivos. Além desses, outros termos merecem curioso destaque como participação, ações públicas, apropriação, projetos, trabalhos, inclusão digital, contexto, relato. Esses termos dizem respeito às ações que são realizadas e relatadas por integrantes do movimento em diferentes partes do Brasil, dentre elas o que foi apresentado nesse trabalho como Esporos, ConecTAZes e outras experimentações, intervenções e políticas . 
$\rightarrow$ Zonas de Colaboração: em segundo lugar, o tema mais tratado nas conversações propostas a partir da pesquisa foram o que se denomina como Zonas de Colaboração. Foi possível identificar 87 registros nessa categoria, extraídos das falas dos integrantes do MetaReciclagem.

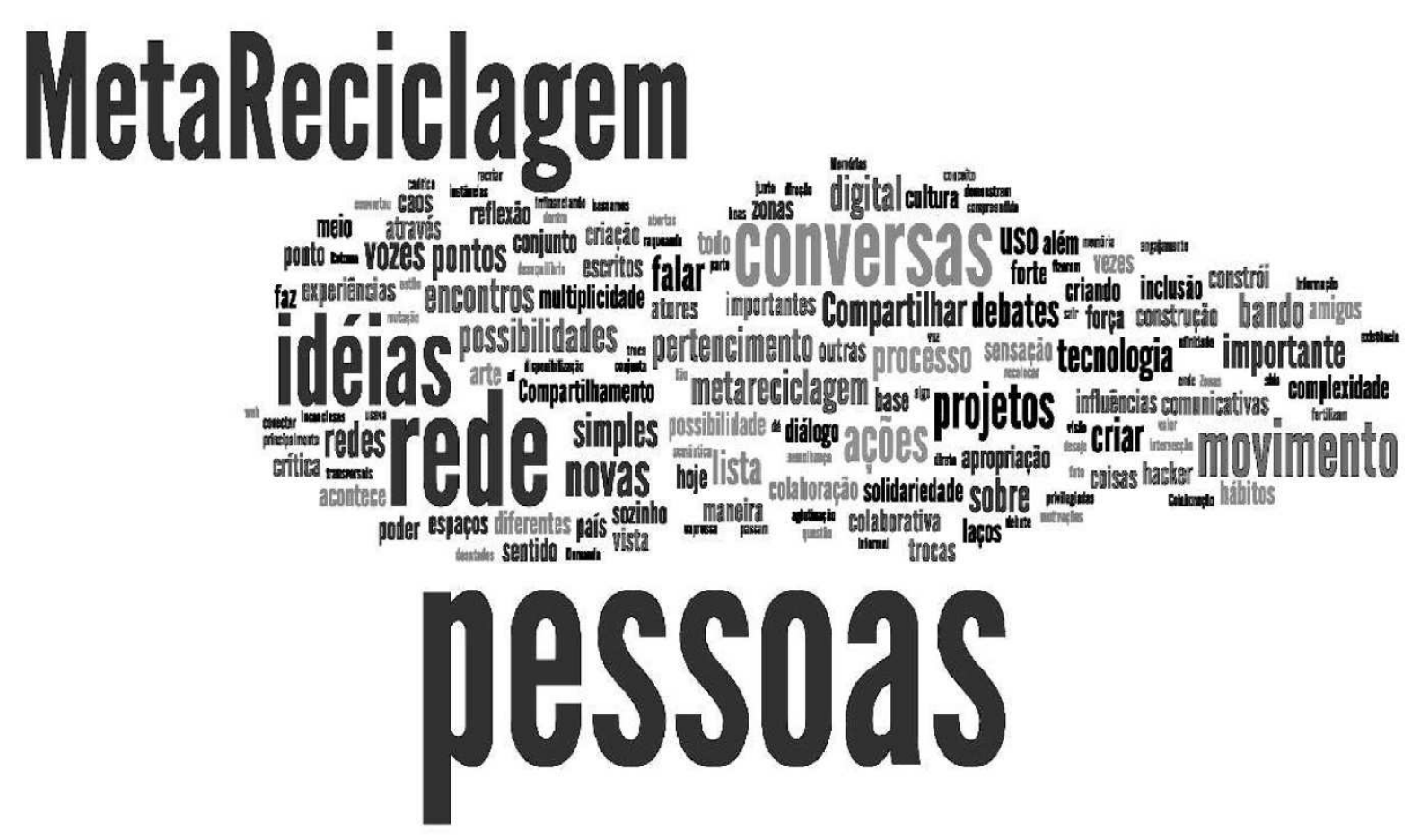

Fig. 23 Nuvem de Tags a Partir de Frases ou Expressões Classificadas na Categoria Zonas de Colaboração. Ferramenta utilizada para essa visualização disponível em: http://www.wordle.net/create Acesso em 10 jun. 2010.

De acordo com a Figura 23 as Zonas de Colaboração têm sobretudo a ver com pessoas, com as conversas, idéias e movimento das pessoas em rede. $O$ MetaReciclagem foi dado como exemplo e significado de Zonas de Colaboração. Essas zonas também parecem expressar as possibilidade dos encontros e compartilhar debates, a noção de bando, de pertencimento, e de poder ocupar espaços diferentes. A ética hacker é retomada com o sinômimo de solidariedade e colaboração, capaz de criando novas idéias e projetos colaborativos por meio das trocas. 
$\rightarrow$ Apropriação da Tecnologia Social: essa categoria recebeu 60 ocorrências de membros do MetaReciclagem.

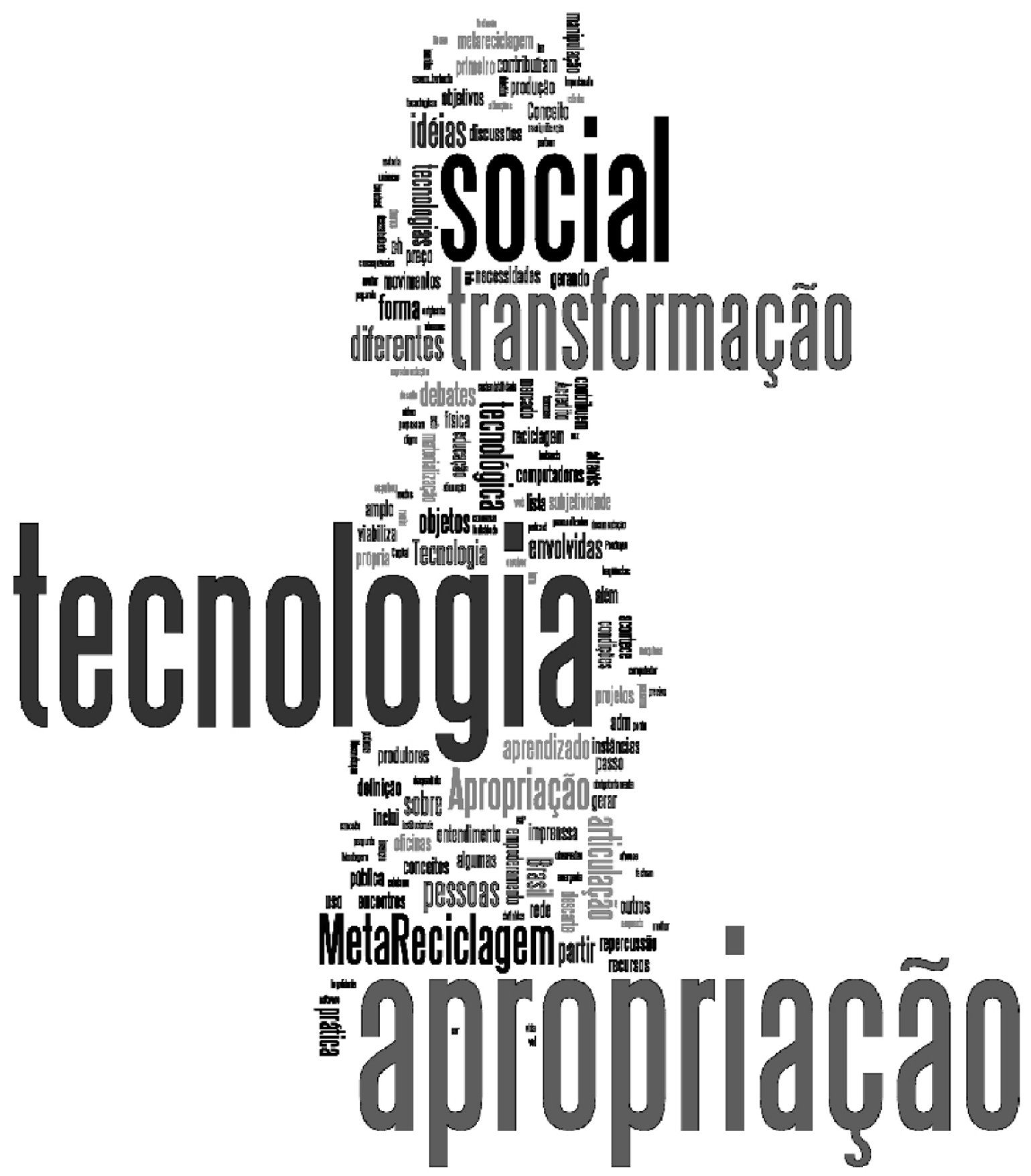

Fig. 24 Nuvem de Tags a Partir de Frases ou Expressões Classificadas na Categoria Apropriação da Tecnologia Social. Ferramenta utilizada para essa visualização disponível em: http://www.wordle.net/create Acesso em 10 jun. 2010.

A categoria Apropriação da Tecnologia Social recebeu o significado de transformação social, aprendizado e articulação principalmente através de práticas diferentes que acontecem no MetaReciclagem. Aqui as pessoas também recebem 
sua importância. Apropriação parece envolver tecnologias, objetos ao mesmo tempo que idéias e debates sobre o tema.

$\rightarrow$ Características da Rede: nessa categoria foram classificados 50 ocorrências de registros nas conversações.

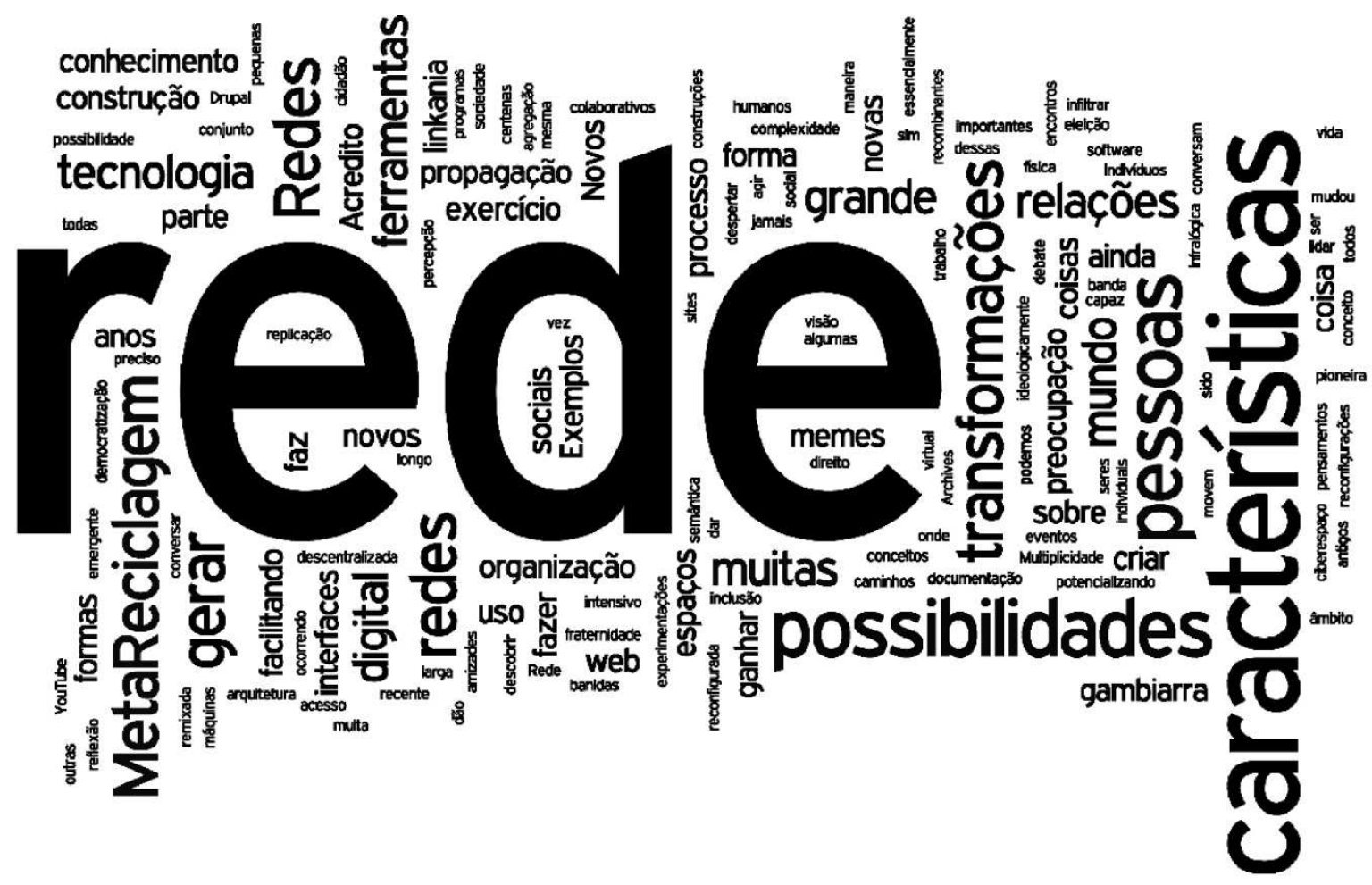

Fig. 25 Nuvem de Tags a Partir de Frases ou Expressões Classificadas na Categoria Características da Rede. Ferramenta utilizada para essa visualização disponível em: http://www.wordle.net/create Acesso em 10 jun. 2010.

$\mathrm{Na}$ opinião dos integrantes do MetaReciclagem, as características da rede referemse a possibilidades, transformações, pessoas e ferramentas. A rede que não é uma só, mas que são muitas redes capazes de gerar formas e novos usos. Através dessa nuvem de tags também é possível observar a preocupação em propagar essas transformações ou memes em espaços ou interfaces diversas.

$\rightarrow$ Metodologia: talvez a categoria que mais se caracterize como peculiar no gráfico e na pesquisa seja a categoria Metodologia/Replicação. Com o índice 
mais baixo de ocorrências, essa categoria recebeu apenas 39 menções nas conversações.

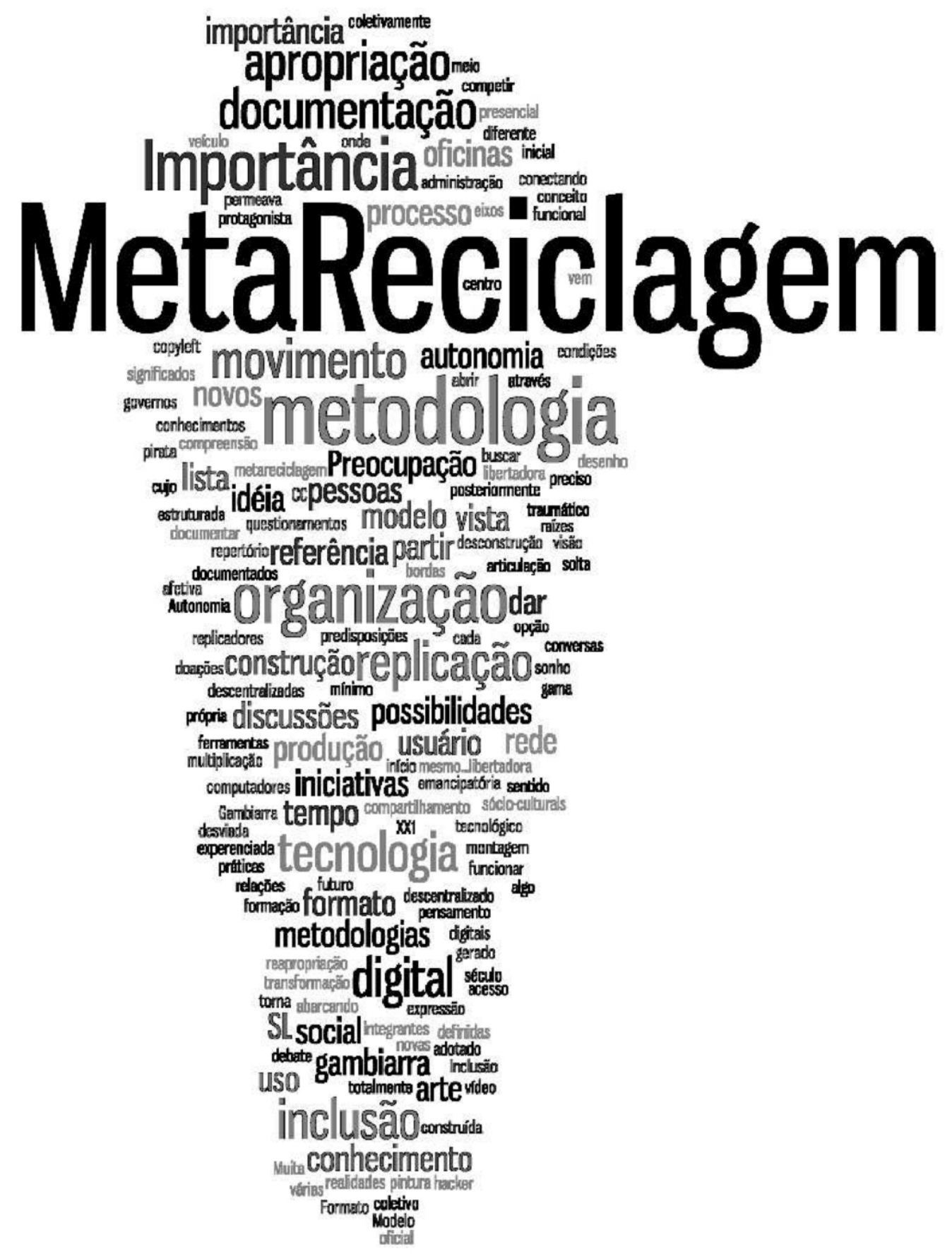

Fig. 26 Nuvem de Tags a Partir de Frases ou Expressões Classificadas na Categoria Metodologia. Ferramenta utilizada para essa visualização disponível em: http://www.wordle.net/create Acesso em 10 jun. 2010.

Apesar de apenas trinta e nove menções, a metodologia apresenta maior variedade de termos mencionados entre os membros do MetaReciclagem. Ela ocupa um lugar 
de importância fundamental na Rede. Através da metodologia é possível a replicação e propagação do movimento em outros agenciamentos coletivos.

Entre suas funções está o fato de servir como referência, base, idéia, forma de documentação. A metodologia do Metareciclagem engloba palavras como arte, gambiarra e inclusão, permitindo a qualquer usuário a construção de iniciativas a partir de um modelo em comum.

\subsection{O que se diz sobre As Zonas de Colaboração}

"As conversas representam e são o MetaReciclagem, a Rede". (Depoimento - Abril/2010)

"Há zonas de colaboração: são o sinônimo de caos, confusão, estado de desequilíbrio ou lugar do prazer (do proibido e da liberdade temporária)". (Depoimento - Março/2010).

As Zonas de Colaboração occorem desde o início do MetaReciclagem. Os diálogos, as conversas, ocuparam o lugar privilegiado a partir da proposta inicial de sair de uma lista de discussão mais técnica que estava sendo realizada no movimento Metá:Fora, para um outro espaço de conversações - o MetaReciclagem - no qual seria possível colocar a Internet, a inclusão digital, em debate de maneira reflexiva, teorizando e compartihando experiências práticas. Para além das discussões sobre softwares, ferramentas, o MetaReciclagem abordou a tecnologia dando preferência às pessoas.

Nessas Zonas de Colaboração descobriu-se quatro categorias importantes com base nas referências mencionadas pelos participantes do MetaReciclagem: 


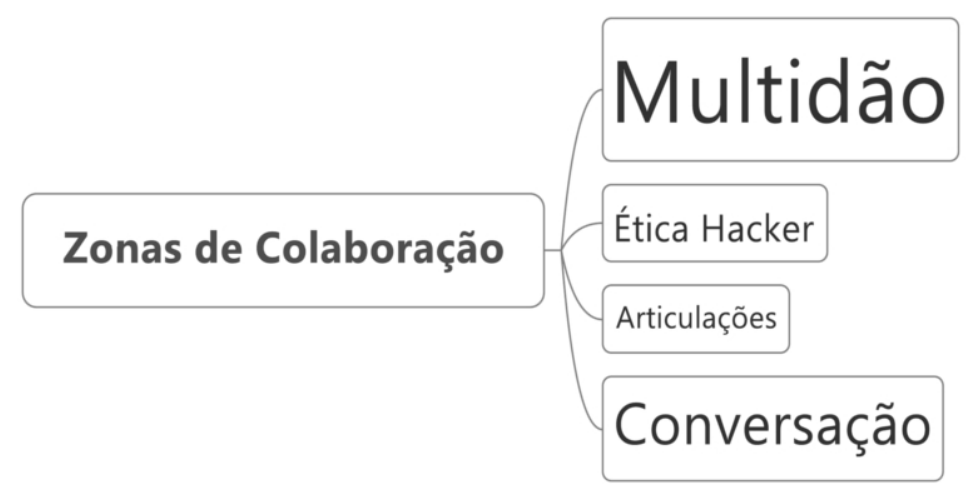

Figura 27. Gráfico Temáticas de Zonas de Colaboração

- Multidão: refere-se tanto ao sentimento de "bando", pertencimento, de não estar só, de fazer parte de um grupo importante, que possui um comum e que discute questões de interesse comum e, para além disso, a potencialização de idéias em uma uma rede de afetos capaz de influenciar outras instrâncias. (Ao todo foram 27 ocorrências). Corresponde às principais expressões:

"sentimento de solidariedade, comunidade, bando". (MetaRec Abril/2010).

"A singularidade se dá na pluralidade dos links e na forma de agregálos, criando um todo de sentido dinâmico." (MetaRec - Abril/2010).

"Provoca as pessoas reverem pontos de vista, hábitos, crenças e conhecimentos prévios, desde que as pessoas se disponham a sair de suas áreas de conforto e caminhem em direção às zonas de colaboração". (MetaRec - Junho/2010).

"laços a mais". (MetaRec - Março/2010).

"A necessidade do outro". (MetaRec - Março/2010).

"Olhares diferentes, multiplicidade do movimento, outros agrupamentos, outra força de associações: pessoas e não-pessoas." (MetaRec - Junho/2010). 
"Efeito estranho: sensação diversa de pertencimento, para além da questão do pertencimento direto que é vinteseculista".(MetaRec Abril/2010).

"As pessoas se agrupam para fortalecer semelhanças, valores, hábitos ou idéias." (MetaRec-Abril/2010).

"Fazer parte do bando, não estar sozinho." (MetaRec - Junho/2010).

"Redes de afeto que nos tornam mais abertos e livres, criando novas possibilidades." (MetaRec-Março/2010).

"O projeto MetaReciclagem hoje é compreendido como rede, englobando pessoas, máquinas, plantas, idéias, objetos cujo uso e função estão constantemente em mutação." (MetaRec - Março/2010).

"O grau de distribuição desta rede é fantástico e se for pra contabilizar o tamanho da vitória seria como organizar a areia da praia". (MetaRec Maio/2010).

- Ética Hacker: as Zonas de Colaboração possuem uma ética comum entre os membros do MetaReciclagem que corresponde à ética hacker ou cultura hacker. Essa ética corresponde à colaboração e disseminação de conhecimento, predominando a visão do conhecimento livre e acessível a todos. (18 ocorrências no total). Pode ser representada pelas expressões:

"forte desejo de compartilhar". (MetaRec-Abril/2010).

"diálogo de uma nova ética hacker em novas instâncias." (MetaRec Abril/2010).

"Novas possibilidades de aprender e ensinar outras pessoas". (MetaRec - Abril/2010). 
"Liberdade imensa de deixar as coisas acontecerem ao seu próprio ritmo, permanecendo uma rede livre, onde o engajamento só acontece se as pessoas realmente quiserem". (MetaRec-Maio/2010).

"Uso do conhecimento adquirido através da rede e a reputação conquistada para respaldar ações locais". (MetaRec - Maio/2010).

"Compartilhamento muitas vezes se constrói de maneira autônoma: se faz sozinho para depois juntar". (MetaRec-Maio/2010).

"Compartilhar por acúmulo e sobreposição de idéias, ações, não se trata de uma criação coletiva com as aguras e o caos inerente ao árduo processo que se configuraria". (MetaRec-Junho/2010).

"Compartilhar: algo a mais que simples disponibilização de informação, a sensação fugaz de conexão, a ilusão de proximidade e autonomia". (MetaRec-Maio/2010).

"Copyleft, informalidade no acesso, redes wi-fi abertas e lan houses". (MetaRec-Abril/2010).

"O 'espírito' metarecicleiro é fundamental principalmente quando falamos das novas tecnologias e a inclusão digital em um país em pleno desenvolvimento e crescimento no cenário mundial." (MetaRec Março/2010).

"estudos em conjunto, escritos em conjunto".(MetaRec - Março/2010).

"Benefícios da relação e construção conjunta com o remoto: raqueamento criativo de espaços". (MetaRec - Março/2010).

"Complexidade: ações que demonstram a inteligência do movimento". (MetaRec-Março/2010).

- Articulações: As articulações aparecem em ocorrências nas Zonas de Colaboração com o surgimento de parcerias e novas possibilidades de 
conversa e influência em outras áreas para além do MetaReciclagem. (16 ocorrências). Dentre as expressões significativas:

"Neste exercício de memória e reflexão o que mais chama a atenção é o fato da dimensão que as idéias tomaram, como fugiram do controle e se replicaram. Afinal quem imaginaria lá em 2002 que hoje metareciclagem teria chegado a tantas pessoas que a entendem como práticas, idéias, conceito, redes, estilo de vida, etc..."(MetaRec Março/2010).

"Os debates e conversações são o nosso alimento, eles fertilizam projetos em várias regiões do país." (MetaRec - Março/2010).

"articulação do MetaReciclagem com instituições". (MetaRec Junho/2010).

"Novos atores no movimento: ONGs, prefeitura". (MetaRec-Abril/2010).

"uso apropriação revitalização e potencialização de conexões". (MetaRec - Março/2010).

"Associações e formação de uma rede interessante." (MetaRec Março/2010).

"MetaReciclagem: uma rede que influencia outras organizações ou projetos". (MetaRec-Março/2010).

- Conversação: a conversação é o elo que torna possível as zonas de colaboração. A simples proposta de conversar através de lista de discussão e outros espaços informacionais como chats, blogs dos membros utilizando outras ferramentas de como Gtalk, Facebook, Orkut. Enfim, as conversações realizadas na rede viabilizaram e criaram novas possibilidades. No MetaReciclagem há valorização das pessos para além do uso da tecnologia. A conversação também tem uma ação que rompe com a hierarquia e permite ter o acesso, o estar em lugares diferentes, jamais imaginados. É a 
conversação no MetaReciclagem que traz a potência de ação e de agenciamente de novos lugares na rede. (23 ocorrências). Dentre as ocorrências observadas, as principais significativas para esse tema:

"Debates como processo de crítica sócio-técnica que está na base de criação da MetaReciclagem: não há como falar de metareciclagem sem falar de trocas comunicativas, encontros e desencontros, debates sobre como refazer, recolocar, recriar, recuperar...”. (MetaRec Março/2010).

"o ponto forte da MetaReciclagem é sua dinâmica cultural, ali as conversas são simultâneas, transversais e inconclusas em vez de um boletim de informações privilegiadas”. (MetaRec-Março/2010).

“Influência e Potência”. (MetaRec - Março/2010).

"o termo metareciclagem surgiu como insight borbulhante entre mais de cem mensagens diárias que rolavam na lista metáfora. Era muita elaboração de idéias". (MetaRec-Março/2010).

"As conversas representam e são o MetaReciclagem, a Rede". (MetaRec - Abril/2010).

“as idéias já estavam postas e as pessoas: empoderadas”. (MetaRec Abril/2010).

"O convívio e as trocas de bits \& vozes". (MetaRec - Abril/2010).

"Assumimos formas diferentes, dependendo de quem é o interlocutor." (MetaRec-Junho/2010).

"Os debates do MetaReciclagem são fundamentais para se pensar processos de entendimento e interpretação que a judam a construir sentido do que é tecnologia dentro de um contexto". (MetaRec Março/2010).

"Encontro gerador acontece, resulta da arte por tecnologia e do texto por palavras. Todas as vozes, as pessoas que participam da lista, 
encontros e tudo mais se concentram em nós desatados que levam a pólos distantes".(MetaRec-Abril/2010).

"Anarquia e humildade intelectual para debate nas discussões". (MetaRec-Maio/2010).

"Conversações: bem público que se converteu em importante moeda de troca." (MetaRec-Maio/2010).

"Ouço falar em MetaReciclagem, cultura digital e apropriação tecnológica através de amigos que trabalham com projetos de inclusão digital no Brasil e encontros que participei". (MetaRec - junho/2010).

"A reflexão crítica das pessoas sobre seu meio e suas ações é instigada pelo grupo e isso é sensacional". (MetaRec-Abri/2010).

"Questões lógicas passam a ficar dissolvidas em inúmeros nós na rede, sem custo". (MetaRec - Abril/2010).

"Redes de afeto que nos tornam mais abertos e livres, criando novas possibilidades." (MetaRec - Maio/2010).

"Valorização das pessoas para além do uso da tecnologia" (MetaRec Maio/2010).

"o importante eram as pessoas e não as ferramentas". (MetaRec Maio/2010).

"O que fica ao longo dos anos no movimento: possibilidade de criar redes de conversas, conectar pessoas e motivações". (MetaRec Junho/2010). 
7.2 0 que se diz sobre os Agenciamentos Coletivos e Transformações

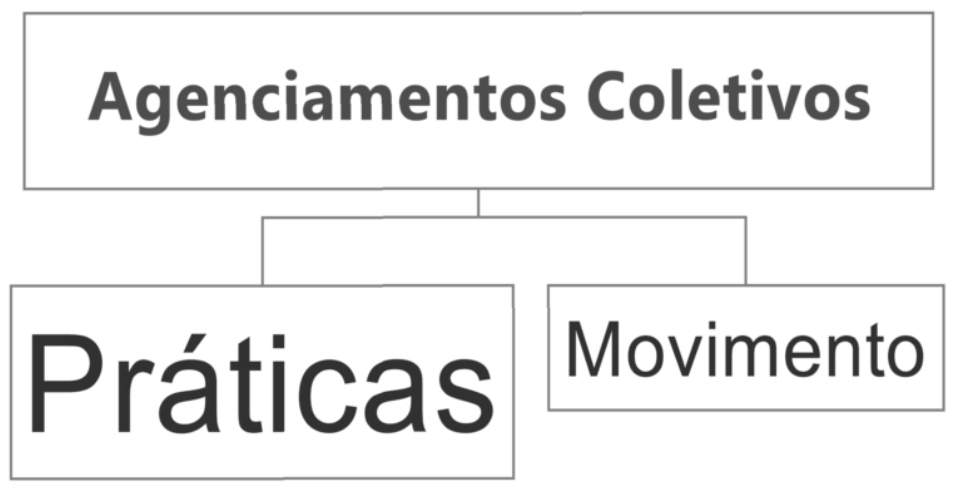

Figura 28. Agenciamentos Coletivos e suas Categorias Temáticas

A categoria Agenciamentos Coletivos foi a mais mencionada durante a discussão proposta pela pesquisa. Houve 141 ocorrências a partir das quais foi possível separar duas subcategorias: Práticas e Movimentos. Esse número intenso de menções no MetaReciclagem indica um resultado positivo para a $1^{\underline{a}}$ e $3^{\text {a }}$ hipótese desse trabalho de pesquisa, respectivamente: a criação das Zonas de Colaboração por meio de ações comunicativas tem por aspectos rizomáticos práticas de apropriação da tecnologia social; a evolução das conversações oriundas da Web resulta em potência para intervir em situações sociais.

- Práticas: referem-se a projetos, influências em outras instâncias, políticas públicas, ONGs, Esporos e coneTAZes e demais aplicações da metodologia de replicação que resultaram em projetos em funcionamento. (Ao todo foram 86 ocorrências). Há dificuldades mencionadas nas práticas como a falta de diálogo com alguns setores e a sensação de que, muitas vezes, é preciso ter paciência no presencial para que os projetos aconteçam. Os encontros do MetaReciclagem também são valorizadas como práticas disseminadoras e replicadoras. Há também o fato de as práticas serem encubadoras de outros negócios entre os membros do MetaReciclagem, culminando na formação de empresas, ONGs, iniciativas privadas que surgiram a partir das práticas da 
MetaReciclagem. Tal formação é tratada como algo positivo pelos integrantes da Rede MetaReciclagem.

"Nos idos de 2001/2002, a gente conversava sobre como ampliar os limites dos programas de "inclusão digital". Temas como apropriação de tecnologia, software livre, hardware livre, infra-lógica, tríade da informação livre inspiraram as primeiras experimentações metarecicleiras Agente Cidadão, Parque Escola, AutoLabs, MídiaTática". (MetaRec - Abril/2010).

"Preocupação na época inicial: como efetivamente aplicar aquilo tudo que conversávamos nos potenciais projetos que poderíamos atuar". (MetaRec-Abril/2010).

"Diferentes experimentações: Converse, Overmundo, Estúdio Livre... Laboratórios experimentais, metaarte... Oficinas, hacklabs, mostras, amostras, viagens, parcerias no exterior, palestras, vídeos, estudos, teses, livros..." (MetaRec-Abril/2010).

"5 anos de Projeto Bailux". (MetaRec-Abril/2010).

"governo federal, estadual e municipal, ONGs, academia". (MetaRec Abril/2010).

"A experiência observada no Meta, com o de uso de listas, blogues, conversações e a atuação descentralizada apoiada pela internet, trouxe elementos importantes para implantar o que chamamos de Gestão ao Vivo no programa Acessa SP." (MetaRec-Maio/2010).

"Exemplos de transformação social: Grande $A B C$, São Paulo, Santo André no Bairro Sacadura Cabral". (MetaRec - Junhol/2010).

"Relato do trabalho em Jarinu". (MetaRec - Junho/2010).

"Caso do Parque Escola em Santo André". (MetaRec - Junho/2010). 
"Exemplos: Rede HumanizaSUS - política nacional de humanização da saúde." (MetaRec - Junho/2010).

"Relato do processo colaborativo em rede com participação de pessoas de diferentes instâncias da comunidade: administração pública, amigos, comunidade". (MetaRec - Abril/2010).

"Abordagem de políticas públicas a partir do lixo eletrônico". (MetaRec Maio/2010).

"Acontecer na metareciclage: Exemplo: encontros." (MetaRec Maio/2010).

"Associações altamente influentes em Políticas Públicas, Inclusão e Cultura Digital". (MetaRec - Maio/2010).

"Outros projetos/dimensões, dentre eles: weblabtk, des).(centro, estúdios livre, orquestra organismo e outros conjuntos". (MetaRec Abril/2010).

"a geração de novos negócios com um esquema de trabalho interessante." (MetaRec - Maio/2010).

"a prática como visão transformadora". (MetaRec - Abril/2010).

"prática inclusiva com participação de pessoas diferentes, trocando experiências". (MetaRec-Maio/2010).

"Outras duas coisas importantes que as conversas em rede fizeram: busca de possíveis parceiros e auxílio no processo de documentação..." (MetaRec-Maio/2010).

"As conversas foram importantes para inspirar, estimular e mapear boas fontes e influências de pesquisa, nas quais nos baseamos para poder realizar experiências e projetos". (MetaRec - Junho/2010). 
"Forma informal, indireta, às vezes nem intencional, contraditória, quase caótica, conseguiu influenciar um monte de iniciativas por aí". (MetaRec-Abril/2010).

"A minha experiência como resposta". (MetaRec-Maio/2010).

"Qualquer integrante que começa a fazer a ponte entre o mundo que está on-line e seu contexto local torna-se uma mola de transformação". (MetaRec-Abril/2010).

"Ações no virtual mais potentes que no presencial".(MetaRec - Abril/2010).

"Mutirão da Gambiarra: promove o diálogo entre iniciativas." (MetaRec Abril/2010).

- Movimento: essa é uma categoria interessante do MetaReciclagem, pois respalda a forma de agir e influenciar instâncias diferenciadas que podem ser outros projetos, políticas, contextos. Nessa categoria, são muito comuns os verbos "hackear", "influenciar", "ocupar", "invadir", que denotam uma forma de agir nem sempre institucionalizada, permitida. A incursão do MetaReciclagem acontece por meio de agenciamentos coletivos. Trata-se de um movimento que procura ocupar espaços e possibilidades na rede, retomando as características de contextos culturais nos quais as pessoas e, principalmente, os participantes se encontram. (Ao todo foram 55 ocorrências referentes a essa forma de agir). Dentre as expressões:

"transversalidade, agenciamento. Forma de agir diferenciada dentro das estruturas políticas. Outro agenciamento". (MetaRec-Abril/2010).

"apropriação, ocupação de espaços". (MetaRec - Abril/2010).

"Incursão na microfísica do poder". ((MetaRec - Abril/2010).

"importância do cultural e do político". (MetaRec - Abril/2010). 
"hacker como artesão da tecnologia" (MetaRec - Abril/2010).

"agir de forma distribuída: influenciando, infiltrando-se". (MetaRec Abril/2010).

"MetaRecicleiros como raqueadores e transmutadores". (MetaRec Abril/2010).

É interessante pensar que essa forma de agir não-institucionalizada corroborou para a disseminação do movimento de maneira mais fácil. Essa característica de agir na rede, de maneira paralela, também foi alvo de discussão entre os membros do MetaReciclagem, uma vez que os participantes tiveram a possibilidade de fazer do movimento uma instituição formal, mas optaram por não fazê-lo (e é importante mencionar que essa foi uma decisão coletiva e contraditória), uma vez que a institucionalização poderia, segundo as convesações, formar estruturas que fixas que impediriam o MetaReciclagem de alcançar espaços mais amplos de influência e uma conversa aberta com todos os setores possíveis.

"No contexto social ou político não temos público-alvo, não temos adversários, categorias do século passado". (MetaRec-Maio/2010).

"De maneira emergente a MetaReciclagem propõe atuar nos espaços públicos tanto físico quanto simbólico, descentralizada e emergente, para além da superficialidade dos novos profetas das redes..que ganham dinheiro dando palestras." (MetaRec - Junho/2010).

"MetaReciclagem se aproveita dos recursos (verbas, poder, conhecimento) e cria circuitos paralelos". (MetaRec - Abril/2010).

"Obedece a outras regras, que não as institucionais (escalada de poder, individualismo, competição)". (MetaRec - Abril/2010).

"Qualquer integrante que começa a fazer a ponte entre o mundo que está on-line e seu contexto local torna-se uma mola de transformação". (MetaRec - Junho/2010). 
"Multiplicidade, compartilhamento, produção de subjetividade, conversção são capazes de gerar intervenções no contexto social, econômico da realidade brasileira, como, precisamente eu não sei..." (MetaRec - Junho/2010).

"Os espaços estão aí, vamos deixando rastros...". (MetaRec - Abril/2010).

"o sentido de comunidade criando economia social". (MetaRec Junho/2010).

"MetaRecicleiros como raqueadores e transmutadores". (MetaRec Abril/2010).

"Vetor de criatividade e inovação que continua reconstruindo a rede, realimentando novos ciclos de trocas, invenção e participação". (MetaRec-Maio/2010).

"Conseguíamos influenciar as políticas públicas justamente porque não precisávamos gastar boa parte de nosso tempo com questões de financiamento, competição, mkt e contabilidade..." (MetaRec - Maio/2010).

"MetaReciclagem leva às últimas conseqüências o que é operar em rede no contexto Brasil". (MetaRec-Maio/2010).

"MetaReciclagem como rede tem uma atuação direta, prática, cotidiana de criação de sentido, engajamento, aprendizado e descobertas." (MetaRec - Abril/2010).

\subsection{O que se diz sobre as Características da Rede}

Ao propor um debate sobre as características da Internet, o objetivo foi mergulhar na visão que os participantes do MetaReciclagem possuíam sobre as possibilidades de pensar a rede como potencializadora do movimento de suas ações de inovação. Ao todo foram 50 ocorrências mencionando as caracteríticas da rede. Nessa categoria principal, não foi possível a decupagem em categorias 
inferiores, uma vez que as temáticas referentes à rede foram mescladas com uma série de intersecções. Devido a esse fato, considerou-se mais expressivo tratas as características em conjunto.

As conversas entre os membros sobre as características da Internet tiveram início a partir do conceito de rede e suas diversas visões/contradições, dentre elas: possibilidade de conexões, democracia e descentralização, potencializadora do conhecimento, não sendo apenas ferramenta. Para alguns integrantes, o conceito de rede não é uma coisa recente. Entretanto a Internet facilitou a ação comunicativa, diminuindo as distâncias entre as pessoas.

"Conceito de rede de acordo com o MetaReciclagem: física, virtual ou infralógica, um conjunto de ambientes e ferramentas". (MetaRec Maio/2010).

"Rede: características de uma tecnologia e suas possibilidades de criar realidades". (MetaRec - Junho/2010).

"Redes são tecnologia? Redes são pessoas e máquinas". (MetaRec Maio/2010).

"As características da rede: complexidade, assunto longo." (MetaRec Maio/2010).

"As redes como um processo de algumas centenas de mil anos". (MetaRec - Junho/2010).

"Redes sempre existiram, a vida é uma grande rede intrincada de relações. Redes tecnológicas são redes de propagação e amplificação". (MetaRec-Abril/2010). 
"linkania = conversações como mecanismo de construções de relações e links". (MetaRec - Maio/2010).

"Multiplicidade me faz pensar na grande rede mundial, mas rede não é uma coisa recente". (MetaRec - Junho/2010).

"exercício mais que prazeroso a maneira descentralizada como as coisas se dão" (MetaRec - Maio/2010).

“democracia e descentralização do poder" (MetaRec - Abril/2010).

Ao trabalhar e agir na rede os integrantes mencionaram a importância da não-hierarquia e a informalidade e a capacidade de lidar com certas "tensões" que a rede representa: a diversidade entre as pessoas que compartilham conhecimento, não-interação, caos informacional. Entretanto, são essas mesmas características que tornam o trabalho mais rico e a interação uma forma de potencialização das capacidades individuais:

"As características de rede presentes no movimento do software livre e em sites e ferramentas públicas como os blogs, Drupal, Flickr, YouTube, Orkut, Bittorrent, etc, foram adotadas de forma pioneira e pragmática pelo MetaReciclagem". (MetaRec-Maio/2010).

"Potencial da web semântica, horizontalidade das relações de comunicação e poder". (MetaRec-Maio/2010).

"Nossa capacidade de agir na web ampliou, novos sistemas, novas possibilidades". (MetaRec-Maio/2010). 
"Angústia da falta de interação, nível de aprofundamento: é preciso aprender a lidar com a tensão emergente como um exercício de articulação da rede viva". (MetaRec - Maio/2010).

"A rede contribui com mudanças pequenas, individuais, de dentro pra fora". (MetaRec-Maio/2010).

Outras características mencionadas pelos metarecicleiros como importantes para se olhar a rede e ver as suas possibilidades de ação foram expressas através dos termos Reputação e Remix. Ao tratar de Reputação os integrantes referem-se a diferentes processos emergentes no qual é possível através de uma busca autônoma verificar e utilizar fontes de conhecimento e referências de projetos e pessoas que foram ou estão sendo bem sucedidos na rede, como fontes de inspiração, inovação e soluções criativas.

O Remix é referenciado como uma maneira de utilizar o que existe na própria rede (conteúdos, ferramentas, mapas) para influenciar pessoas, montar projetos e criar conhecimento. A amplitude do remix também traduz a expressão " possibilidade de fazer barulho" em qualquer lugar que se esteja a partir de disponibilização de propostas interessantes para quem queira ouvir. $O$ MetaReciclagem trata com um público não-definido previamente, de pessoas que se interessaram em debater sobre a Internet e suas ferramentas, sempre priorizando a conversação.

"Quem ganhar relevância aparece, que não ganhar some na rede e vira causo dos Archives". (MetaRec - Maio/2010).

"espírito de compartilhamento que leva à fraternidade, amizades que se movem pela paixão, remixada e temperada". (MetaRec-Abril/2010).

"A organização em rede amplia a escala de distribuição, construção e documentação do conhecimento, facilitando a replicação". (MetaRec - 
Maio/2010).

"Já somos uma geração P2P ainda que a galera broadcast faça mais barulho". (MetaRec-Maio/2010).

Em relação à potência das características da rede para influenciar e gerar projetos interessantes, com uma atuação participativa e política de grupos resulta em uma posição contraditória entre os integrantes do movimento. Uns acreditam que são as características da Internet e suas ferramentas as responsáveis pelas mudanças sociais e intervenções, outros acreditam que essas mudanças resultam de uma postura participativa de certos grupos e não da Internet em si.

"Tenho muitas dúvidas sobre a possibilidade da rede gerar transformações, mas permite indivíduos + pariticipativos mais criativos descobrir e interagir de modo sinergético". (MetaRec - Maio/2010).

"Acredito que a rede possa sim gerar intervenções, potencializando o encontro de pessoas, pensamentos, bem como a autonomia". (MetaRec - Maio/2010).

"Acredito que a rede é uma ferramenta potente para construção de conhecimentos e para atuação política". (MetaRec - Maio/2010).

"As transformações já estão ocorrendo. A rede é o contexto: a percepção de ser rede descortinou o processo, empoderando a pessoa comum". (MetaRec-Maio/2010).

"Não as características da rede em si, mas as pessoas que se apropriam dessas características em suas ações." (MetaRec - Maio/2010). 
"A rede é capaz de gerar transformações e reconfigurações nas relações sociais, econômicas na sociedade brasileira: micropolíticas da rede". (MetaRec-Maio/2010).

"As características da rede são uma saída para agilizar, transformar antigos processos de mobilização social. No âmbito artístico temos projetos colaborativos, onde, jamais conseguiríamos chegar sem esses novos modelos de conversação". (MetaRec-Maio/2010).

"A rede está sendo reconfigurada pelo seu grupo mais atuante, abrindo espaços importantes para expansão das práticas recombinantes que tinham sido ideologicamente banidas do mundo dos mass media”. (MetaRec-Maio/2010).

"MetaReciclagem como um inoculador: gambiarra, dar um jeito, se virar, ganham uma nova qualidade no mundo das redes. $O$ digital é essencialmente recombinande e a diversidade cultural é uma grande gambiarra”. (MetaRec-Maio/2010).

"Exemplos de novas possibilidades na rede: eleição, mídias sociais, aumento do potencial de circulação de memes”. (MetaRec-Maio/2010).

"As características da rede podem gerar transformações." (MetaRec Maio/2010).

"Novos caminhos de acesso às pessoas e suas identidades em rede: criar uma interferência e despertar atenção". (MetaRec-Maio/2010).

"Principal característica da rede e do MetaReciclagem: infiltrar em todas as possibilidades e fazer barulho". (MetaRec-Maio/2010). 


\subsection{O se diz sobre Apropriação da Tecnologia Social}

O que seria a apropriação da tecnologia social? Qual é o tipping point que transforma o uso em apropriação, ou o reuso em uma solução satisfatória para problemas reais que enfrentamos no dia-a-dia? De acordo com os participantes do MetaReciclagem a apropriação é acima de tudo um fenômeno social advindo do uso inteligente, de descobertas autônomas, sobre como apropriar-se da Internet e das ferramentas de comunicação e demais tecnologias em um contexto cultural específico. Inclusão, empoderamento, características culturais são termos importantes para essa categoria.

Segundo os integrantes da Rede a apropriação da tecnologia social nasceu como um dos objetivos iniciais do MetaReciclagem e busca efetivamente ter como resultado transformações pessoais e a melhoria na qualidade de vida. A apropriação de qualquer tipo de tecnologia constitui-se em uma "merge" de pessoas e ferramentas para o bem estar comum. De acordo com os participantes, o meio pelo qual a apropriação ocorre é através do compartilhamento de informações, aprendizagem, manipulação e recombinação de equipamentos e software.

Sobre a apropriação da tecnologia social ainda é conveniente mencionar a visão dos participantes da MetaReciclagem sobre a posição de vantagem do Brasil diante de outros países. A visão de que o Brasil, ainda que prescinda de uma rede de acesso em escala muito grande que viabilize a inclusão digital apresenta uma cultura do imporviso, ou seja, uma certa facilidade em descobrir formas de inventar soluções para o acesso. Dessa facilidade e do interesse surgem a apropriação tecnológica. Ao todo foram 60 ocorrências do tema Apropriação.

"A vantagem do brasileiro: ele é rápido na apropriação da plataforma, não usa manual, pergunta pro amigo ou improvisa." (MetaRec - Abril/2010).

"A lan house na favela é a maior prova de apropriação de tecnologia no Brasil. Jovens estão na web pagando preço de picolé. Brasil tá bem na fita". (MetaRec - Abril/2010). 
"Diversas tecnologias ecoam...barbante, telefone, pombo-correio, email, baleias com suas freqüências, cigarras..." (MetaRec - Junho/2010).

"Pra mim aquela situação originária da metareciclagem enquanto prática e definição de seu conceito já era uma super apropriação tecnológica que estava gerando muita transformação social (cuja dimensão só percebemos nos anos seguintes)". (MetaRec-Maio/2010).

"A transformação se viabiliza a partir do entendimento do seu papel no mundo, e do outro. Conversar, compartilhar, produzir com e entre diferentes através da rede é colocar os recursos tecnológicos disponíveis a serviço das transformações sociais". (MetaRec - Maio/2010).

"Quando a apropriação tecnológica é feita a partir de idéias como sustentabilidade, reuso, reciclagem, aprendizado amplo, ludicidade, e servem de cunha para processos de discussão e transformação pessoal e do grupo, passamos a investir tempo e recursos não apenas para usar uma tecnologia, mas para fazê-lo em benefício próprio e da comunidade em que estamos inseridos". (MetaRec - Junho/2010).

"O MetaReciclagem oferece uma alternativa de apropriação tecnológica. As discussões partem e se destinam a lugares e objetivos completamente diversos dos compartilhados pelos produtores originais da tecnologia". (MetaRec - Junho/2010).

A partir da categoria Apropriação da Tecnologia Social foi possível extrair 3 subcategorias temáticas:

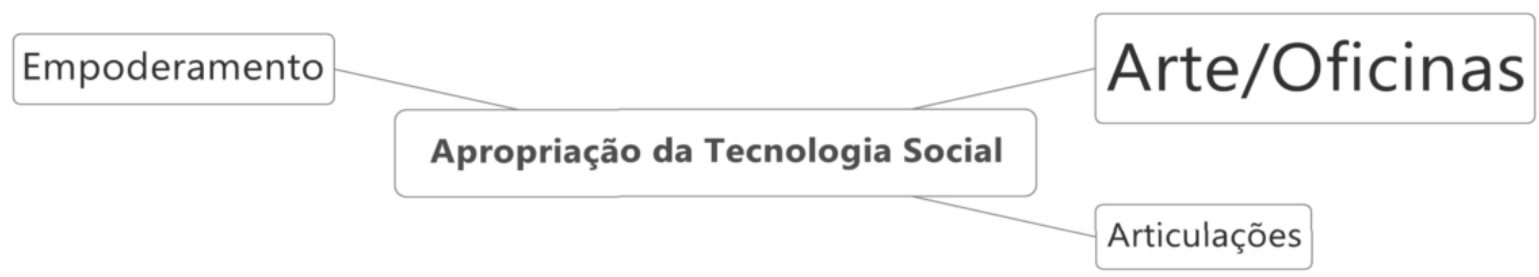

Fig. 29 Apropriação da Tecnologia Social e suas Categorias Temáticas 
- Articulações: refere-se às articulações em diferentes instâncias em projetos sociais, políticas públicas, em diferentes locais do Brasil através da materialização das idéias do MetaReciclagem. Ao todo, houve 12 ocorrências temáticas nessa subcategoria. Abaixo, algumas delas expressam as articulações.

"Acredito que os debates no MetaReciclagem contribuíram para a apropriação da tecnologia e transformação social: primeiro na própria articulação e materialização de idéias, depois pela repercussão para outros movimentos, imprenssa e pessoas envolvidas na adm pública e educação". (MetaRec - Junho/2010).

"Reuso de software, hardware livre, envolver comunidades de forma autônoma, não ter medo, articulação de projetos locais." (MetaRec Maio/2010).

"decisões sobre tecnologia social em diferentes instâncias institucionais" (MetaRec - Maio/2010).

"articulação que viabiliza propostas de apropriação da tecnologia social." (MetaRec - Junho/2010).

"Ensinar a apropriação para o bem-estar". (MetaRec - Maio/2010).

"Aprendizagem mais do que comandos de computador, idéias transformadoras de pessoas". (MetaRec-Maio/2010).

"Os ciclos de obsolescência, o uso, preço, condições técnicas de manipulação, transformação e descarte etc. são definidos por necessidades de mercado, capacidade de produção, do retorno ao acionista, ficam de lado interesses nacionais de transformação social e desenvolvimento econômico e humano." (MetaRec - Maio/2010). 
- Arte/Oficinas: essa categoria refere-se à prática de projetos, oficinas e intervenções artísticas e lúdicas utilizando a tecnologia. Essa prática contribuiu para a disseminação do conhecimento já apropriado entre os integrantes do MetaReciclagem para outros contextos culturais, posto que as oficinas também são um modelo de replicação do movimento. Além disso, os trabalhos artísticos estimularam a liberdade de invenção de novos usos da tecnologia entre os participantes de diversos projetos sociais. Refere-se também ao momento em que o projeto deixa de ter como foco o reuso de computadores, o acesso, a tecnologia em si para dar espaço à subjetividade e descobertas de soluções criativas para o cotidiano das pessoas. (Ao todo, foram 31 ocorrências mencionando as oficinas e a proposta artística no MetaReciclagem como espaços de apropriação da tecnologia social).

"A arte como forma de aproximação e de método lúdico de aprendizado, o aprendizado compartilhado tudo isso foi debatido em lista ou em encontros". (MetaRec - Maio/2010).

"discussões e oficinas gerando formas de apropriação e empoderamento". (MetaRec - Maio/2010).

"MetaReciclagem: o encontro que melhor me afetou e despertou para o universo tecnológico: pela primeira vez desejei me apropriar da tecnologia sem ressentimento da imposição". (MetaRec - Maio/2010).

"Apropriação envolve um ato criador: entendimento ou interpretação da essência das coisas e reinvenção a partir disto". (MetaRec - Maio/2010).

"Reinventando os usos dos objetos, despertando a atenção para a necessidade de mudar a cultura do consumo abusivo, descarte e desperdício". (MetaRec-Maio/2010).

"Montagem das próprias máquinas, gabinetes pintados e personalizados". (MetaRec-Maio/2010).

"O projeto não queria ser mais um de reciclagem de computadores". (MetaRec-Maio/2010). 
"Ação abrangente, apropriação inclui várias instâncias que ressignificam dos objetos às subjetividades". (MetaRec-Maio/2010).

"Incentivar inovação e invenção - criatividade nas pontas". (MetaRec Maio/2010).

"Propõe a ressignificação dos objetos, fatos, situações, subjetividade, criação". (MetaRec-Maio/2010).

"Apropriação envolve um ato criador: entendimento ou interpretação da essência das coisas e reinvenção a partir disto". (MetaRec - Maio/2010).

"Reinventando os usos dos objetos, despertando a atenção para a necessidade de mudar a cultura do consumo abusivo, descarte e desperdício". (MetaRec-Maio/2010).

"A arte como forma de aproximação e de método lúdico de aprendizado, o aprendizado compartilhado tudo isso foi debatido em lista ou em encontros". (MetaRec - Maio/2010).

- Empoderamento: o conceito de apropriação da tecnologia social no MetaReciclagem passa pela capacidade de potencializar pessoas e situações. A apropriação é um saber construído a partir de experiências reais com a tecnologia que leva as pessoas a um olhar melhor sobre si e sobre suas capacidades de agir e intervir na cultura onde se encontram. Talvez 0 empoderamento seja um dos objetivos últimos dos movimentos de inclusão digital no Brasil: o acesso e o que se pode fazer a partir desse acesso às TICs, visando à autonomia de ação dos indivíduos por meio dos recursos que são criados por ele para viver de uma maneira mais criativa, participativa. Ao todo foram 12 ocorrências com o termo empoderamento nas conversações:

"Conceito de tecnologia social = apropriação pela população para inclusão social e melhoria das condições de vida". (MetaRec - Abril/2010). 
"A apropriação da tecnologia social já acontece de forma descentralizada e emergente, à margem das corporações e no limite da legalidade". (MetaRec-Abril/2010).

"o desafio é nunca esquecer de ir além da tecnologia física". (MetaRecAbril/2010).

"Produção de subjetividade através das oficinas (podcast, edição de vídeo e áudio, fotografia digital com equipamentos simples e celulares, produção de blogs, animação 2D) assim acreditamos que podemos gerar um empoderamento da tecnologia que vai além do mero uso de emails e do Orkut”. (MetaRec-Maio/2010).

"Compreender a tecnologia como extensão do homem, como ferramenta para sua rede de afetos". (MetaRec-Maio/2010).

“Outro horizonte, tecnologia como a ponte". (MetaRec - Junho/2010).

“(...) hoje a prática inclui diferentes fazeres, desde o fazer-fazer, até o fazer-falar e o fazer-pensar, os computadores são quase um detalhe". (MetaRec - Junho/2010). 


\subsubsection{O que se diz sobre Metodologia}

A Metodologia talvez seja o cerce da Rede MetaReciclagem e tem por "jeito de fazer" a Replicação. Entretanto, contextos culturais diversos fazem com que o ato de replicar a MetaReciclagem em uma cidade, região, ou até mesmo eventos, transformem esse "fazer" em algo original por quem quer que seja concebido. A metodologia do MetaReciclagem tem por modelo a metodologia de desenvolvimento do software livre e se desenvolve de maneira coletiva. A ausência de um centro disseminador, mas a aplicação de Esporos e ConecTazes facilitam a disseminação do conhecimento sobre a Internet e suas possibilidades, o empoderamento e, quem sabe, em última instância a reciclagem de computadores. Bem sucedida, pode-se dizer que é a metodologia de replicação não-institucionalizada e não-proprietária do MetaReciclagem - essa prática emergente, "quase despreocupada" e que ao mesmo tempo que busca intervir e alcançar realidades diversas - a responsável por preservar as características e potencialidades da Rede MetaReciclagem onde quer que ela seja replicada: a não-institucionalização e as conversas com diferentes instâncias da sociedade.

Outra consideração importante sobre a Metodologia, além de sua forma híbrida, é a preocupação denunciada pelos integrantes do movimento com a documentação: publicação e registros em listas de discussão das conversações e processos que estão acontecendo em diversas regiões do Brasil. O conteúdo dessas listas tem se transformado em livros e materiais que podem ser utilizados por qualquer pessoa na rede para dar início a projetos ou ações.

$\mathrm{Na}$ categoria Metodologia, o termo abrange todas as demais categorias principais que utilizamos na pesquisa, como pode ser observado nas frases abaixo. Dessa forma, não foi possível separar a Metodologia em subcategorias. Ao todo foram 39 ocorrências do termo metodologia ou referenciando-a nas discussões. Abaixo, as referências principais: 
"De início, em 2002, a idéia era receber doações de computadores e colocá-los para funcionar e destiná-los a pessoas que não tinham equipamentos ou à montagem de telecentros". (MetaRec - Junho/2010).

"O MetaReciclagem trouxe novos ventos, condições de possibilidades. Uma metodologia emancipatória, libertadora e ativa para a apropriação da tecnologia. Trabalhando com a idéia da desconstrução da tecnologia para a reapropriação".(MetaRec - Junho/2010).

"Metodologia da autonomia".(MetaRec - Junho/2010).

"estratégias puxadinho e gambiarra". (MetaRec-Abril/2010).

"MetaReciclagem como um movimento gerado a partir de software livre, copyleft, movimento creative commons, e posteriormente foi adotado por iniciativas de inclusão digital de governos e ongs". (MetaRec - Abril/2010).

"metodologia metareciclagem de autonomia e multiplicação". (MetaRec Abril/2010).

"Preocupação com a documentação do processo e divulgação". (MetaRec - Junho/2010).

"Importância da documentação, dar sentido aos pontos de vista, abrir possibilidades, dar visibilidade". (MetaRec - Maio/2010).

"Me impressionou o nível do pensamento que permeava as discussões, bem como a metodologia e a simplicidade do encontro." (MetaRec Junho/2010).

"A importância das listas de discussão como ferramentas fundamentais para articulação de idéias e práticas, compartilhamento e informações, discussões descentralizadas". (MetaRec-Maio/2010).

"Modelo descentralizado, colaborativo". (MetaRec - Junho/2010). 
"A metodologia, através das oficinas e conversas vem fazendo com que essa apropriação seja experenciada a partir de um repertório pessoal e, ao mesmo tempo, coletivamente. É como se a "versão" oficial fosse desviada, ou construída por cada usuário, uma subversão mesmo...libertadora, pirata, hacker". (MetaRec-Abril/2010).

“Muita replicação, incontrolável”. (MetaRec - Abril/2010).

"Autonomia na organização, na mistura das relações com consciência operante". (MetaRec-Abril/2010).

"Formato híbrido de comportamento da rede MetaReciclagem: uma construção de relação funcional, mental e afetiva ao mesmo tempo não estruturada, não hierárquica, não totalmente solta." (MetaRec Junho/2010).

“Limites não dados, bordas não definidas". (MetaRec - Junho/2010).

"Importância da metodologia de replicação: replicação sempre". (MetaRec - Maio/2010).

"Inclusão digital com o conceito de tecnologia social metodologias e técnicas participativas e transformadoras". (MetaRec - Maio/2010).

Forma híbrida de trabalhar - não só organização, não só rede, mas alguma coisa no meio." (MetaRec-Abril/2010).

"A importância das oficinas do MetaReciclagem para disseminação de conhecimento". (MetaRec-Abril/2010).

"Comportamento coletivo evitou a formação de uma organização centralizada". (MetaRec-Abri/2010).

"Publicações do movimento em vista: MutiroLogia do Mutirão da Gambiarra". (MetaRec - Junho/2010). 


\section{Implicações da Pesquisa: “...Aqui tem um Bando de Louco...”}

Uma imensidão de comunidades de desenvolvedores de softwares, blogueiros, de pessoas linkadas espalhados pelo mundo com objetivos semelhantes na produção colaborativa. Muita gente ronda pelos bastidores cibernéticos.

Este foi um trabalho sobre conversações. Começei a explicar como emerge essas conversas usando a expressão do Projeto Metáfora nas redes que habitamos. Metáfora sempre foi uma TAZ. Um espaço informacional impermanente por natureza. Assim, o Metáfora não acontece mais, persiste como uma conversa de 2003. Quando pessoas se organizavam em redes para criar experimentos, invenções e gambiarras. O MetaReciclagem é um desses experimentos. Uma articulação em rede que fez eco às propostas da apropriação da tecnologia social.

Pelo menos para mim, todo esse processo que é 'a MetaReciclagem' nos remete a idéia de inquietude potencializada. Potência de querer transformar, de engajamento no espaço informacional. De apropriação e replicação das relações tranformadoras. Atuamos na arte, na política pública, na cultura... Estamos construindo novas possibilidades de transformação social. Somos parte de um movimento colaborativo imenso.

Todo esse processo começou a criar rizomas. Um modelo começou a emergir das entranhas da rede. Gosto de pensar que o paradoxo se torna paradigma no ritmo de uma cultura de remix. O conhecimento começa a se libertar das instituições e, faz da rede um repositório colaborativo.

A atuação das pessoas em blogs, twitter, Orkut, Facebook ou em qualquer não-lugar informacional faz com que a comunicação não mais seja monopólio da mídia de massa, ou da idéia da comunicação de um para muitos. Com a Internet a comunicação se distribui em rede. E, desta forma, opera numa conversação de muitos para muitos. As pessoas consomem e produzem conversas sem a necessidade de pedir permissão. Publicar é conversar. Independente da mídia que suporta a informação.

As Zonas de colaboração formam-se em meio ao caos e desorganização 
informacional na Internet. Numa dinâmica cultural de encontros em rede, as conversas são simultâneas, transversais e inconclusas. Entretanto, apesar das características difusas e da multiplicidade de opiniões e vontades, as pessoas reconhecem o valor das conversações e sua potência para alterar realidades em contextos sociais. Essa correlação de forças imanentes é expressa na rede como zonas de colaboração cujo conceito é o espaço informacional onde as pessoas comuns estão engajadas no desenvolvimento de comunidades, nas relações, nas conversações.

Cabe-nos pensar como essa problemática está sendo contemplada e como o estudo das teorias da comunicação podem desvelar o processo da formação de uma nova geração de comunicadores. O século XXI exige, portanto, modificações estruturais no poder. É nesse cenário que as redes sociais adquirem importância. É sobre esse jogo de força que a MetaReciclagem, como proposta de ocupação de espaços, do reuso da tecnologia e da apropriação atuar e impacta em algumas políticas públicas. A troca de conhecimentos é capaz de gerar mudanças nos diferentes contextos culturais a partir das conversas informais.

Nessas Zonas de Colaboração, a importância das pessoas frente à tecnologia constitui-se como proposta inicial do MetaReciclagem. Esse fato pode ser observado pela prática de divulgação da conversa/pesquisa ou intervenção para outras instâncias blogs, listas, nas quais um post ou proposta de projeto perdem o controle e se diluem para outros lugares. Tal prática é produtiva para gerar uma potência que agrega multidões com interesses em comum.

Do mesmo modo que pesquisadores científicos permitem a todos os demais em seus campos de estudo, examinar e utilizar suas descobertas, para serem testadas e desenvolvidas além do ponto em que se encontram, os hackers que participam do projeto Linux permitem a todos os demais utilizar, testar e desenvolver seus programas. Em pesquisa, isso é conhecido como "ética cientifica". Na programação, ela recebe o nome de código-fonte aberto, ou opensource. A esse modelo se assemelha à Academia de Platão, na qual os alunos não eram vistos como a meta dos ensinamentos, mas sim como companheiros na aprendizagem .

As pessoas envolvidas com a a criação e desenvolvimento da Internet têm 
uma natureza radical, que consiste em propor uma postura alternativa para a sociedade da rede - um padrão que questiona a ética protestante predominante. Desde sua criação, a Internet não tem nenhum orgão dirigente central que guia seu desenvolvimento ou que controla seu conteúdo. Ao contrário, sua tecnologia ainda é desenvolvida por uma comunidade aberta de hackers. Essa comunidade discute idéias, que só se tornam padrões se a maior parte da comunidade da Internet achar que elas são boas e começarem a usá-las. O hacker é o artesão da tecnologia. Ocupa os espaços informacionais. Diminui as distâncias entre seres humanos. A proposta da sociedade da colaboração é a ética hacker.

A ética hacker preconizando o compartilhamento de conhecimentos, o acesso livre e o uso de ferramentas, bem como o modelo descentralizado e colaborativo, bem sucedido, de criação em rede do software livre serviram de espelho e resultaram em ações do MetaReciclagem em rede através de intervenções ou influências em projetos e políticas públicas no Brasil.

MetaReciclagem, ao influenciar políticas públicas de inclusão digital trouxe, em seu cerne, a proposta de apropriação da tecnologia social como forma transformação social. Essa proposta pode ser replicada através de metodologias emancipatórias e autônomas que se adequam a contextos culturais diversos, como foi demonstrado por meio de esporos e conectazes como embriões de ações nos depoimentos dos participantes da rede.

Não há um centro disseminador de conhecimento e práticas, mas uma difusão de informações provenientes de muitos lugares. Entretanto, a apropriação não advém somente das características inerentes à rede tais como multiplicidade e possibilidade de compartilhar, mas de ações efetivas e iniciativas de participantes em atuar, "invadir" e ocupar espaços informacionais e públicos.

De acordo com os participantes do MetaReciclagem o Brasil recebe reconhecimento, agregando uma posição de destaque em ações na Internet. A emergência da reputação, reconhecimento, citações, referências e de ampla discussão, além do copyleft, propõe uma forma de agir em rede no Brasil que, até mesmo no limite da legalidade e sem bordas definidas, facilita a apropriação da tecnologia social e a disseminação do conhecimento. O improviso, a gambiarra são comportamentos que trazem consigo a descoberta de novas possibilidades de 
intervenção.

Deve-se apontar que a característica rizomática e não-institucionalizada da Rede MetaReciclagem propõe uma metodologia de replicação eficaz que propicia a inclusão digital por meio de uma diversidade cultural e demandas emergentes das pontas do movimento, facilitando o surgimento de Esporos e Conectazes. Ressalta-se a importância das oficinas e eventos para apropriação e divulgação, bem como a experiência dos que teorizam sobre inclusão digital e a experiências das práticas de projetos que utilizam a metodologia.

Estamos em um tempo em que não há volta e o uso das conversações oriundas da Web irão cada vez mais influenciar as políticas e intervenções sociais. No MetaReciclagem, a predominância da categoria agenciamentos coletivos vem agregada ao uso do verbo crer que é recorrente nas conversações coletadas, nos posicionamentos e opiniões. Tal composição não se configura em uma contradição, mas no valor que o movimento dá às pessoas em detrimento da tecnologia, o que confirma que a Rede é constituída por crenças e desejos, além de ferramentas, fios e equipamentos. E que, para o bem ou para o mal, há um comum compartilhado que se desenrola em projetos e ações efetivas.

Alguns dizem que a teconologia reproduz a idéia de prótese; que ela "cola" no homem. As fábricas seriam lugares onde sempre são produzidas novas formas de homens: primeiro, o homem_mão, depois o homem_ferramenta, em seguida, o homem_máquina e, finalmente, o homem_aparelhos_eletrônicos. Repetindo: essa é a história da humanidade. A máquina distende a mão do homem ao ponto do homem se tornar a máquina, ou a máquina se tornar o homem. Oras, tanto faz. Somos homem_computadores, homem_celulares, homem_agendas_eletrônicas... somos homens. Homens em rede.

Na verdade, nossa experiência no MetaReciclagem faz um link importante com esse pensamento. Pois, o limite da apropriação tecnológica, numa abordagem mais conceitual, é a constatação de que o desafio de lidar com a máquina é ser a máquina. Brincamos com os games, desafiamos os limites como se fôssemos os heróis. Programadores tem como objetivo apenas criar um percurso rítmico para as mentes em ação.

O desafio está em se valer da máquina para se constituir como homem. O 
código é a interface do homem com a sua máquina_prótese. Quebrar e decifrar os protocolos que controlam o sistema nos aproximam da condição pós-humana. A sociedade se torna, então, refém de um sistema homem_máquina_protocolo.

A promessa da Internet é o retorno da voz. Esse retorno se dá pela apropriação da tecnologia e pelas inúmeras possibilidades de usar o sistema homem_máquina_protocolo em benefício do sujeito e da comunidade. O caminho do controle é o mesmo do que aquele proposto pela liberdade.

Por outro lado, temos uma multidão que se alimenta destas contradições e, que encontra na rede um ambiente propício para expressar a sua potência. $A$ multidão hiperconectada só se faz possível quando a apropriação tecnológica possibilita o compartilhamento de interesse comuns. As pessoas se aproximam. Criam e recriam comununidades. As pessoas se juntam, estão linkadas pela ação comum.

Ao tratar de apropriação da tecnologia social é importante mencionar o aspecto artístico do movimento que se preocupou em pensar o uso das novas tecnologias de maneira criativa e inovadora, abrindo espaços para a expressão da subjetividade e, ao mesmo tempo, empoderamento das pessoas por meio da ação comunicativa e uso de software e hardware. A abordagem da MetaReciclagem não-proprietária e ampla, sem fronteiras definidas, possui ampla capacidade de estabelecer articulações com diversas intâncias nacionais e internacionais que culminam por transformar a rede em um múltiplo criador de novas circunstâncias propícias para a inovação de técnicas e usos da Internet e suas ferramentas.

Dentre as inúmeras categorias apresentadas na metodologia desse trabalho de pesquisa por meio da análise temática é importante mencionar que cada uma delas merece um estudo específico, tanto pela abundância de dados coletatos quanto pela possibilidade de desvelar aprofundamentos interessantes e relevantes sobre a visão e ação dos integrantes do MetaReciclagem. A análise apresentada por meio desse estudo é inicial e com amplas possibilidades de desdobramentos.

Ao final, ainda é possível nos perguntar: o que é a MetaReciclagem? O que é essa rede de pessoas cuja influência é capaz de alcançar, invadir e ocupar lugares ainda tão inesperados? É possível perceber também a dificuldade dos próprios integrantes em responder à questão, tendo em vista que o olhar dos fundadores se 
distorce ao perceber as ações do MetaReciclagem atualmente. Certamente, devese ao fato de que, após 8 anos de existência e continuidade nas conversações (como foi possível observar por meio dos dados quantitativos), após ser muitas vezes decretada morta por alguns participantes alhures, a Lista de Discussão foi apropriada por seus integrantes (e ainda chegam novas pessoas na lista a cada instante), dispostos a debater, a questionar a Internet e suas possibilidades de uso e implicações. Participar de tal proposta não é uma atividade cotidiana fácil, de acordo com os depoimentos coletados, mas conturbada e acima de tudo desorganizada. Entretando, é essa desorganização bem-sucedida que abre espaços para outras interpretações sobre a MetaReciclagem e outros agenciamentos.

Será que há algum modelo que poderá ser visualizado ao longo dos anos de conversação/interação por meio da Lista de Discussão ou http://rede.metareciclagem.org/ entre os membros dessa rede? Quais as tags e assuntos mais polêmicos e que foram capazes de gerar mais threads, capturando a atenção e o maior envolvimento por meio de opiniões dos membros do movimento ao longo dos anos? Será possível estabelecer um estudo comparativo entre as conversações do MetaReciclagem e outras redes na Internet? Essas são algumas pesquisas que são viáveis de ser apontadas e necessárias para estudos futuros a partir desse trabalho de pesquisa.

Finalizo essa pesquisa na esperança de que os metarecicleiros se reconheçam nesse processo, ao menos, em alguma parte, posto que a intervenção foi algo que contou com a genuína participação de uma rede que - pelo seu tempo de (im)permanência, pelos projetos já desenvolvidos e com o número de postagens aqui mencionadas, além das qualidade das discussões nos fazem ter orgulho de ser metarecicleiro. Pois é, aqui tem um bando de loucos... que quere Sugere-se a continuação do estudo longitudinal realizado de maneira quantitativa em pesquisas posteriores a respeito do MetaReciclagem com o objetivo de extrair um acompanhamento histórico das formas de interação ao longo dos meses do ano no MetaReciclagem. m para um mundo melhor. 


\section{Referências Bibliográficas}

ARISTÓTELES. Metafísica. São Paulo: Abril Cultural, 1984. (Coleção: Os Pensadores).

BARBROOK, R. Imaginary futures: from thinking machines to the global village. Willesden, London, 2006. Disponível em < http://imaginaryfutures.net $>$ Acesso em: 19 jul. 2008.

Cyber-communism: how the Americans are superseding capitalism in cyberspace. Science as culture. n. 1, v. 9, p. 5-40, 2000. Disponível em: < http://www.imaginaryfutures.net/other-works/> Acesso em 12 set. 2008.

BARDIN, L. Análise de conteúdo. Lisboa, Portugal: Edições 70, 2009.

BENKLER, Y. The wealth of the networks: how social production transforms markets and freedom. New Haven: Yale University Press, 2006. Disponível em: <http://www.benkler.org/Benkler_Wealth_Of_Networks.pdf> Acesso em: 16 jul. 2006.

BEY, H. TAZ: zona autônoma temporária. São Paulo: Editora Conrad, 2001.

BORGES, J. L. Obras completas. São Paulo: Globo, 1998. v. 1.

BOYD, Danah. Taken out of context: american teen sociality in networked publics. 2008. 393f. Dissertation (Doctor of Philosophy in Information Manegement and Systems) University of California, Berkeley, 2008.

CASTELLS, M. A sociedade em rede: a era da informação: economia, sociedade e cultura. 9.ed. São Paulo: Paz e Terra, 2006. v.1.

COSTA, R. Por um novo conceito de comunidade: redes sociais, comunidades pessoais, inteligência coletiva. Interface. Botucatu: SP, v. 9, n. 17, p. 235-248, ago. 2005. Disponível em: <http://www.scielo.br/scielo.php?script=sci_arttext\&pid=S1414$32832005000200003 \&$ Ing=en\&nrm=iso > . Acesso em: 10 dec. 2008.

- Inteligência afluente e ação coletiva: a expansão das redes sociais e o problema da assimetria indivíduo/grupo. Razón y palabra, n.41, 2004. Disponível em:<http://www.cem.itesm.mx/dacs/publicaciones/logos/anteriores/n41/rdacosta.html >. Acesso em 28 jul. 2008.

DALTON, M.; DIMANTAS, H. Sobre conversas e revoluções. Le monde diplomatique: caderno Brasil/sociedade em rede. São Paulo, 2009. Disponível em: http://diplomatique.uol.com.br/acervo.php?id=2388\&PHPSESSID=2992afb2cd65c85 94faad2ff286459fc Acesso em: 11 jul. 2010.

DANGINO, R.; BRANDAO, F. C.; NOVAES, H. T. Sobre o marco-analítico conceitual da tecnologia social. IN: Tecnologia social: uma estratégia para o desenvolvimento. Rio de Janeiro: Fundação Banco do Brasil, 2004. 
DANGINO, R.; NOVAES, H. Adequação socio-técnica e economia solidária. Campinas: Mimeog; Unicamp, 2003.

De MASI, D. O ócio criativo. 2. ed. Rio de Janeiro: Sextante, 2000.

DELEUZE, G.; GUATTARI, F. Mil platôs: capitalismo e esquizofrenia. São Paulo: Editora 34, 1995. v. 1.

Mil platôs: capitalismo e esquizofrenia. São Paulo: Editora 34, 1995. v. 2.

Mil platôs: capitalismo e esquizofrenia. São Paulo: Editora 34, 1995. v. 5.

DELEUZE, G. Conversações. Rio de Janeiro: Ed. 34, 1994.

. Foucault. São Paulo: Brasiliense, 1985.

\begin{tabular}{cccc}
. Le curs de gilles deleuze sur spinoza. Paris, França, 1978. Tradução: \\
\hline Francisco & Traverso & Fuchs. & Disponível
\end{tabular} http://www.webdeleuze.com/php/texte.php?cle=194\&groupe=Spinoza\&langue =5

Acesso em: 10 jun. 2008.

DIMANTAS, H. Linkania: a sociedade da colaboração. São Paulo: Editora Senac, 2010.

2003.

Marketing hacker: a revolução dos mercados. Rio de Janeiro: Garamond,

GUZZI, Adriana Araújo. Participação pública, comunicação e inclusão digital. 2006. 127f. Dissertação (Mestrado em Comunicação e Semiótica) - Pontifícia Universidade Católica de São Paulo, São Paulo, 2006.

ESCOBAR, A. Welcome to cyberia: notes on the anthropology of the cyberculture. Current anthropology. v.35, n. 3, p. 211-231. Jun. 1994. Disponível em: < http://www.unc.edu/ aescobar/text/eng/arturowelc.pdf >. Acesso em: 20 jul. 2008.

ESPINOSA, B. Ética. In: Os pensadores. São Paulo: Abril Cultural, 1973.

FONSECA, F.; DIMANTAS, H. Multirão da gambiarra. São Paulo, 2009. Disponível em: <http://rede.metareciclagem.org/wiki/Mutir\%C3\%A3o-ProjetoInicial>. Acesso em: 27 out. 2009.

Fonseca, F. ; MATIELO, D. C. . Notes from the field: e-waste in Brasil - lixo deletrônico and metareciclagem. International review of information ethics. v. 11, p. 16-19, 2009.

FONSECA, F. Tecnologia social. São Paulo, 2004. Disponível em: < http://portal.softwarelivre.org/news/2010> Acesso em: 28 fev. 2006. 
FOUCAULT, M. Nascimento da biopolítica: curso dado no Collège de France (1978-1979). Tradução: Eduardo Brandão.São Paulo: Martins Fontes, 2008. (Coleção Tópicos). Graal, 2005.

Microfísica do poder. 21.ed. Tradução: Roberto Machado. Rio de Janeiro: . História da sexualidade I: a vontade de saber. Rio de Janeiro: Graal, 1993.

O pensamento do exterior. São Paulo: Princípio, 1990.

GARCIA, D.; LOVINK, G. The abc of tatical media. Holanda, 1997. Disponível em: < assail.files.wordpress.com/2007/11/abc-of-tactical-media.pdf> Acesso em: 24 jun. 2009.

GUATTARI, F. Caosmose: um novo paradigma estético. São Paulo: Editora 34, 2006.

HABERMAS, J. Direito e democracia: entre facticidade e validade. Trad. Flávio Beno Siebeneichler. Rio de Janeiro: Tempo Brasileiro, 1997. v. 2.

Teoría de la accion communicativa: crítica a la razón funcionalista. Madrid: Taurus, 1987. v. 1.

HALL, S. A identidade cultural na pós-modernidade. Tradução Tomaz Tadeu da Silva e Guacira Lopes Louro. 11 ed. Rio de Janeiro: DP\&A, 2006.

HARDT, Michael; NEGRI, Antonio. Multidão: guerra e democracia na era do império. Rio de Janeiro: Record, 2005.

HEIDEGGER, M. Basic writings: from being and time to the task of thinking. London: Harperperennial and Modern Thought, 2008.

HEIDEGGER, M. Introdução à filosofia. Tradução: Marco Antonio Casanova. São Paulo: Martins Fontes, 2008.

Ser e tempo. Petrópolis, RJ: Vozes, 1997. v. 2.

Da experiência do pensar. Porto Alegre: Globo, 1968.

HIMANEN, P. Pólis virtual robin wood no hiperespaço. São Paulo, 2003. Disponível em: < http://www.softwarelivre.org/news/904> Acesso em: 20 jul. 2008.

The hacker ethic: and the spirit of the informational age. New York: Randon House, 2001.

ITO, M. et. al. Living and learning with new media. Berkley, CA: MacArthur 
Foundation, 2008. Disponível em http://digitalyouth.ischool.berkeley.edu/report Acesso em 25 fev. 2009.

JARDIM, Fabiana Alves; OTERO, Martina Rillo. Reflexões sobre a construção do conceito de tecnologia social. IN: Tecnologia social: uma estratégia para o desenvolvimento. Rio de Janeiro: Fundação Banco do Brasil, 2004.

JENKINS, H. Convergence culture: where old and new media collide. New York: NYU Press, 2008.

From youtube to youniversity. Cambridge, MA. 2007. Disponível em: http://www.henryjenkins.org/2007/02/from youtube to youniversity.html Acesso em: 10 jun. 2007.

JOHNSON, S. Emergência: a dinâmica de rede em formigas, cidades e softwares. Rio de Janeiro: Jorge Zahar; 2003.

LATOUR, Bruno. Reassembling the social: an introduction to actor-networktheory. New York: Oxford University Press, 2005.

LAZZARATO, M. From capital-labour to capital-life. Ephemera: theory \& politics in organization. v. 4(3), p. 187-208, 2004.

LE BOTERF, G. Pesquisa participante: propostas e reflexões metodológicas. In: BRANDÃO, C.R. (Org.) Repensando a pesquisa participante. São Paulo: Brasiliense, 1999.

LEIBNIZ, Gottfried Wilhelm. La monadologie. Paris : Librairie Général Française, 1991.

LESSIG, L. Remix: making art and commerce thrive in the hybrid economy. New York: Penguin Press, 2008.

LEVINE, R. et. al. The cluetrain manifesto: the end of business as usual. New York: Basic Books, 2001.

LÉVY, P. A conexão planetária: o mercado, o ciberespaço, a consciência. São Paulo: Editora 34, 2001.

A inteligência coletiva: por uma antropologia do ciberespaço. 4 ed. Tradução: Luiz Paulo Rouanet. São Paulo: Loyola, 2003.

LOPES, M.I.V. de. Pesquisa em comunicação. 8. ed. São Paulo: Edições Loyola, 2005. (Série Comunicação).

MARÍAS, J. Los estilos de la filosofia. Tradução: Sylvio Horta. Madrid, 2000. Disponível em: http://www.hottopos.com/harvard4/jmshdg.htm Acesso em 05 abr. 2009. 
NEGRI, A.; HARDT, M. Empire. London: Harvard University Press, 2000.

PARENTE, A.; Enredando o pensamento: redes de transformação e subjetividade. In: Tramas da rede. Porto Alegre: Sulina, 2004. Org. André Parente.

RAYMOND, E. S. The cathedral \& the bazzar: musings on linux and open source by an accidental revolutionary. Sebastopol, CA: O'Reilly \& Associates, 1999. Disponível em: <http://www.geocities.com/CollegePark/Union/3590/pt-cathedralbazaar.html> Acesso em 08 jan. 2008.

RHEINGOLD, H. Smart mobs: the next social revolution. New York: Perseus Books, 2003.

ROSAS, Ricardo. Truquenologia: elementos para se pensar uma teoria da gambiarra tecnológica. São Paulo, 2007. Disponível em: http://virgulaimagem.redezero.org/ricardo-rosas-in-memoriam/ Acesso em 18 jun. 2010.

SAAD, E. Estratégias para a mídia digital: internet, informação e comunicação. São Paulo: Senac, 2003.

SEARLS, D., WEINBERGER, D.; World of ends: what the internet is and how to stop mistaking it for something else. 2003. Disponível em: < http://www.worldofends.com> Acesso em 25 ago. 2004.

SHIRKY, C. Here comes everybody: the power of organizing without organizations. New York: Penguin Press, 2008.

SILVER, D. Internet/cyberculture/digital culture/ new media/ fill-in-the-blank. New media \& society. London: Sage Publications, v. 6, p. 55-64, 2004. Disponível em: http://online.sagepub.com/cgi/searchresults Acesso em 15 maio 2008.

SILVERMAN, D. Interpretação de dados qualitativos: métodos para análise de entrevistas, textos e interações. Tradução: Magda França Lopes. 3ed. Porto Alegre: Artmed, 2009.

SODRÉ, M. Antropológica do espelho: uma teoria da comunicação linear e em rede. Rio de Janeiro: Vozes, 2002.

STALLMAN, R. M. Free software, free society: selected essays. Boston: GNU Press, 2002. Disponível em: < http://www.gnu.org/philosophy/fsfs/rms-essays.pdf> Acesso em: 17 jul. 2008.

SUROWIECKI, J. The wisdom of crowds. New York: Anchor Books, 2005.

TARDE, Gabriel. Monadologia e sociologia: e outros ensaios. Tradução Paulo Neves. São Paulo: Cosac Naify, 2007. 
A opinião e as massas. Tradução: Eduardo Brandão. São Paulo: Martins Fontes, 2005.

TEIXEIRA, R. R. O desempenho de um serviço de atenção primária à saúde na perspectiva da inteligência coletiva. Interface v. 9, n. 17, Aug. 2005. Disponível em: http://www.scielo.br/scielo.php?script=sci arttext\&pid=S141432832005000200002\& $\underline{\mathrm{ng}=\mathrm{en} \& \mathrm{nrm}=i \mathrm{so}}$ Acesso em $05 \mathrm{fev}$ 2009. doi: 10.1590/S1414-32832005000200002.

As redes de trabalho afetivo e a contribuição da saúdepara a emergência de uma outra concepção de público. In: RESEARCH CONFERENCE RETHINKING "THE PUBLIC" IN PUBLIC HEALTH: Neoliberalism, structural violence, and epidemics of inequality in Latin América. 2004, San Diego: Anais... San Diego, CA. Center for Iberian and Latin American Studies, University of California-San Diego, 2004b.

THIOLLENT, M. J. M. Metodologia da pesquisa-ação. 15.e.d. São Paulo: Cortez, 2007. (Coleção temas básicos da pesquisa-ação).

TORVALDS, L.; DIAMOND, D. Só por prazer: Linux - bastidores da sua criação. Rio de Janeiro: Campus, 2001.

UGARTE, D. El poder de las redes. Espanha, 2007. Disponível em: < http://www.deugarte.com/manual-ilustrado-para-ciberactivistas> Acesso em 13 out. 2008.

ULPIANO, C. Liberdade e pensamento em Espinosa. Disponível em: < http://www.youtube.com/watch?gl=US\&feature=related\&v=KMhuVkSDQPs> acesso em 25 set. 2008. http://www.claudioulpiano.org.br/textos_texto02.html> Acesso em: 29 jan. 2009.

VIRILIO, P. Cibermundo: a política do pior. Lisboa: Teorema, 2000.

WEINBERGER, D.. Everything is miscellaneous: the power of the new digital disorder. New York: Times Books Henry Holt ans Company, 2007.

. The hyperlinked metaphysis of web. 2006. Disponível em: http://www.hyperorg.com/misc/metaphysics/ Acesso em: 31 março de 2009.

.The long conversation. UK, 2004. Disponível em: < http://www.guardian.co.uk/technology/2004/may/27/media.newmedia> Acesso em: 20 jul. 2008.

Small pieces loosely joined: a unified theory of the web. New York: Perseus Books, 2002. 
